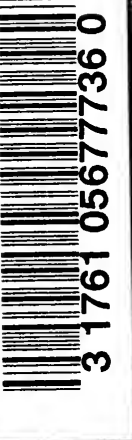


-

18\%: 


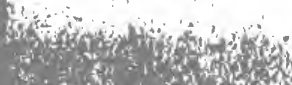

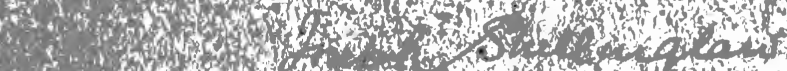
48

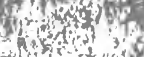
$+2$ 30 (2) xis

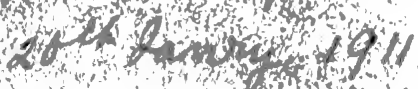
Lex:?

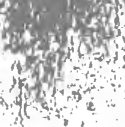

की

w?

4 d

E sond

His

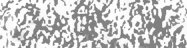

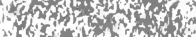

is sut of

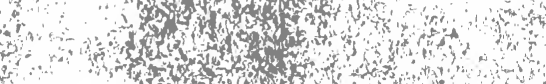

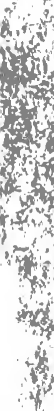

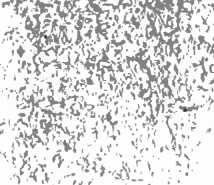

a 010

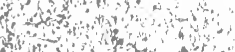

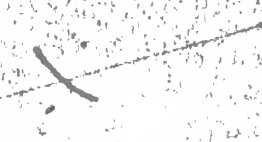

ris

is $y$

protos is $x^{2}-12$

ints 16. \& tont ind 40 (f)

tis

sitis . . (2)

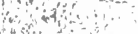

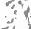

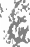

to

(n)

7 tot

on on on

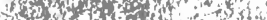

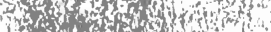

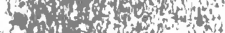

A.

is

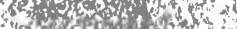

ind

is

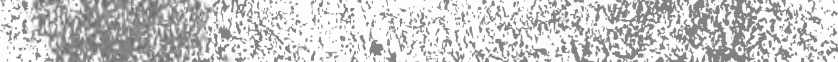

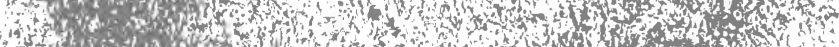
at

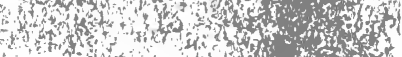
or and is distom

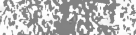
ind 0 is

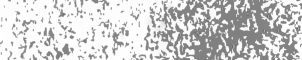
ard and

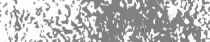

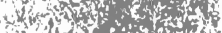

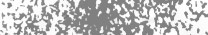
ry

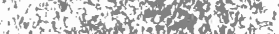

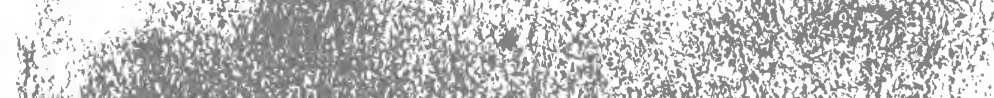
f.

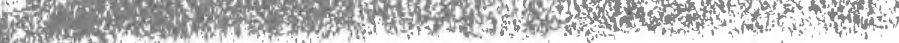




\section{Digitized by the Internet Archive in 2007 with funding from Microsoft Corporation}


CHRISTIANITY AND SOCIAL QUESTIONS 


\section{STUDIES IN THEOLOGY}

A Critical Introduction to the New Testament.

By Arthur Sameel Peake, D.D.

[Ready.

Faith and its Psychology.

By the Rev. Williass R. INaE, D.D.

[Ready.

Philosophy and Religion.

By the Rev. Hastings Rashdall, D.Litt. (Oxon),

D.C.L. (Durham), F.B.A.

[Ready.

Revelation and Inspiration.

By the Rev. JAMES ORR, D.D.

[Ready.

Christianity and Social Questions.

By the Ven. W. Conningham, F.B.A, D.D., D.Sc.

An Encyclopædia of Theology.

[Ready.

By the Rev. A. M. Falrbairs, D.D., D.Litt., LL.D.

A Critical Introduction to the Old Testament.

By the Rev. Grorge Buchanan Gray, D.D., D. Litt.

History of Christian Thought from the Apostolic

Age to the Reformation.

By Herbert B. Workman, D. Litt.

History of Christian Thought from the Reformation to Kant.

By A. C. McGiffert, Ph.D., D.D.

History of Christian Thought since Kant.

By the Rev. Edward Caldwell Moore, D.D.

The Christian Hope: A Study in the Doctrine of the Last Things.

By W. Adasis Brown, Ph.D., D.D.

Redemption and Atonement.

By the Right Rev. the Bishop of Grodcester. 


\section{CHRISTIANITY AND \\ SOCIAL QUESTIONS}

BY

W. CUNNINGHAM, D.D., F.B.A.

ARCHDEACON OF ELY; FELLOW OF TRINITY COLLEGE AND HON. FELLOW OF GONVILLE AND CAIUS COLLEGE, CAMBRIDGE; CORRESPONDING MEMBER OF THE MASSACHUSETTS HISTORICAL SOCIETY AND FORMERLY LECTURER IN HARVARD UNIVERSITY

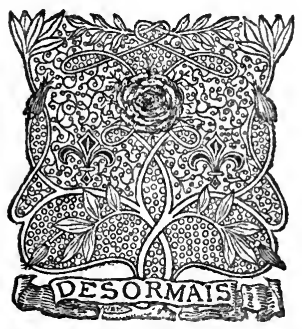

LONDON : DUCKWORTH \& CO.

3 HENRIETTA ST., COVENT GARDEN

I9IO 


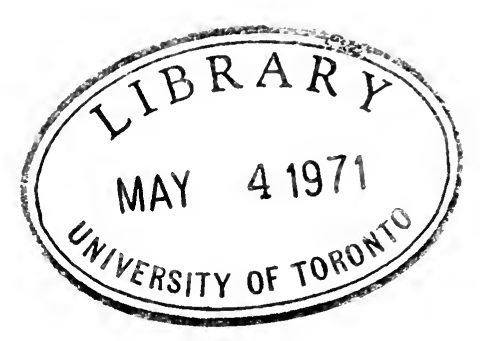

All rights reserved.

$$
\begin{aligned}
& \text { AX } \\
& 51 \\
& 08
\end{aligned}
$$




\section{PREFACE}

The study of social questions differs from economic investigation, partly on account of the greater width of the field that must be surveyed, and partly because the aims, with which the enquiries are pursued, are quite distinct. The economist is concerned with the causes of material prosperity; for him 'things are in the saddle and ride mankind.' Some of us, however, while we recognise that economic studies are necessary as a preliminary, regard them as merely a preliminary; we are not satisfied to dwell only on the increase of the comforts and conveniences of life, but aim also at the improvement of human life itself. The object we set ourselves is to study the means by which Man may attain to welfare in all its aspects; not only to command over material comforts, but to elevation of mind and character as well.

The economist, who is studying business conditions among progressive peoples in the present day, finds it convenient to leave many important aspects of human life-political and religious-in the background; and there is some danger that he will only take account of them occasionally and spasmodically, or even ignore them altogether. A useful corrective to such onesidedness may be found in historical studies, as the interaction, between political and religious movements on the one hand and economic conditions and progress on the other, is kept constantly before the mind; the student of social problems must endeavour to take this wider outlook over human affairs in the present day. $\mathrm{He}$ 
cannot dare to leave any element of human activitypolitical, religious, or economic-deliberately in the background: there must be an effort to take full account of human life in all its aspects, and to deal with each in due proportion.

This book is an attempt to set forth, from a Christian standpoint, the relative importance of all the forces which make for human welfare, or militate against it. This is a large subject, and I have had some difficulty in compressing it into the space at my disposal. On many of the points raised I have thought it sufficient to refer to the somewhat fuller treatment in books or papers of my own, and the titles of these are quoted without the author's name. With the view of giving precision to my exposition, I have frequently referred to writers who look at the problems from a different standpoint and see them in another light, but I have endeavoured to avoid polemics of every kind. The bibliography has been planned as a brief guide to those readers who desire to go more fully into some of the highly debateable questions raised in this brief sketch.

W. C.

Trinity College, Cambridge,

February 1910. 


\section{CONTENTS}

\section{PART I. WORLD-WIDE INFLUENCES}

\section{CHAPTER I. PHYSICAL CONDITIONS}

1. Conditions of Animal Life Page

(a) The Principle of Population, . . . . . . 1

(b) The Law of Diminishing Return, . . . . 3

2. The Progress of Man- . . . . . . 5

(a) In Knowledge and Power of Organisation, . . 5

(b). In Character, . • . . . . . . 7

3. Prospects of Further Advance • + , , 9

(a) Danger of Decadence, . . . . , . 9

(b) Criteria of Wise Organisation, . . . . . . 10

4. Common Sense and Christianity . . . . 13

(a) Grounds for Believing in the Discipline of the Race, 15

(b) The Widening of the Sphere of Hope, . . . . 17

(c) Wise Philanthropy and Christian Charity, . . 17

5. Christian Philosophy of Lrfe- . . . . 19

(a) As Reconciling Inconsistent Claims, . . . 19

(b) Its Effectiveness as a Practical Power, . . . 20

\section{CHAP'TER II. RACIAL DIFFERENCES}

1. The Defects of the Lower Races . . . . 21

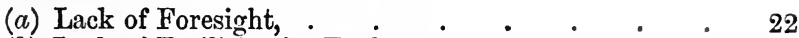

(b) Lack of Facilities for Exchange, . . . . : 24

(c) Socialist Attacks on Private Accumulation, - . 24

2. The Inter-Racial Struggle for Existence • • $\quad 27$

(a) Adaptability to New Conditions, . . . . 28

(b) The Maintenance of Numbers, . . . . . 29 
3. The Contact of Two Races on the Same Soll • - 30

(a) Competition for Land, . . . . . . 31

(b) The Demand for Labour, . . . . . . 32

4. The Persistence of Racial Distinctions . . . 34

(a) Amalgamation and Assimilation, . . . . 35

(b) Economic Cosmopolitanism, • • • • • 36

5. The Christian Claim for fair Play on Behalf of Native Races . . . . . . . . 40

(a) The Safeguards of Ordinary Morality Insufficient, . 40

(b) A Specifically Christian Duty, . . . . . 43

(c) The Co-operation of Official and Missionary Effort, . 44

\section{CHAPTER III. CIVIL AUTHORITY}

1. The Enforcing of Right and Justice • • . 46

(a) The Superhuman Element in the State, . . . 47

(b) The Responsibility of Rulers, . . . . . 48

(c) The Duties of Subjects, . . . . . . . 49

(d) Economic Aspects of Good Government, . . . 50

2. The Utilitarian State . . . . . . . 52

(a) Lack of Public Spirit in the Management of Civil Affairs, . . . . . . . . 54

(b) The Spasmodic Recognition of Supreme Right, . $\quad 55$

(c) Obstacles to Arbitration, . . . . . $\quad 56$

(d) The Divergence of the English and the American Conceptions of Political Life, . . . $\quad 57$

3. Corruption and Decadence . $\quad$. $\quad . \quad$. $\quad . \quad 59$

(a) The Nemesis of a Defective Sense of Duty, . $\quad$. 59

(b) Statesmanship and Statescraft, . . . . . 62

\section{PART II. NATIONAL ECONOMIC LIFE}

CHAPTER I. THE FUNCTIONS OF GOVERNMENT

1. Justice And Expediency . . . . . . . 66

(a) The Punishment of Crime, . . . . . 66

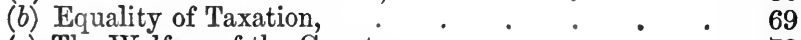

(c) The Welfare of the Country, . . . . 72

(d) Christian Influence on Political Life, : $\quad$ : 75 
2. Favourabue Compiriong mor Economic Liptu

(a) The Maintenance of a Well-ordered Community, . 79

(b) Compulsion and Reward, . • • • • $\quad 82$

(c) Certainty of Reward and Freedom to Use, : $\quad$. 83

3. Grounds for State Interference . • • • $\quad 85$

(a) Limitations to the Rights of Private Property, , $\quad 85$

(b) Preventing the Relative Waste of Land, . . $\quad$. 86

(c) Co-ordinating the Operation of Capital, . . . 88

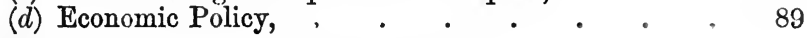

4. Criteria of Healthy Economic Life - • $\quad$ - $\quad 91$

(a) Unemployment as a Symptom of Disease, . . 91

(b) The Defectiveness of Money Measurement, . 93

(c) The Danger of Neglecting Money Measurement

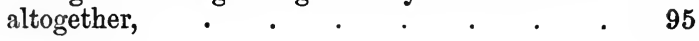

\section{CHAPTER II. THE REWARD OF SERVICES}

1. The Framework of Sochety and the Force of Com-

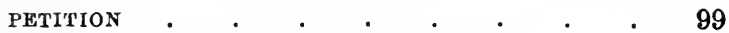

(a) The Double Character of Social Problems, . $\quad$. $\quad 99$

(b) The Social Services of Capitalists and Landowners, . 100

(c) The Regulation of Competition, . . . . 104

(d) The Elimination of Competition, . . . . 106

2. The Reward of Labour . . . . . . . 109

(a) Class Distinctions in Personal Service, . . . 109

(b) Ladders for Rising in the World, . . . . 111

(c) Restricting Supply and Attracting Public Custom, . 113

(d) Inflated Reward, . . . . . . . 120

(e) Sweated Industries, . . . . . . . 121

3. The Profit on Capital . . . . . . 123

(a) Profit and Interest; . . . . . . . 123

(b) Interest and Extortion, . • • • • . . . 126

(c) The Credit System and the Community, . , : 127

(d) Waste and Organisation, . . . . . . 129

(e) Municipal Enterprise, · . . . • . . 131

(f) Monopoly and the Public Interest, . . . . 134

4. The Return from Land . • . . , . . 137

(a) The Services of Landowners, . . . . . 137

(b) The Various Uses of Land, . . . . 139

(c) Residuary Payments, . . . . : : 140 
(d) The Increment in Progressive Countries, . . . 143

(e) State-Appropriation of Exceptional Reward, . . 145

5. Drastic Remedies . . . . . . . . 148

(a) State-Appropriation of Capital and Land, $\dot{P}^{\cdot} 148$

(b) Abandonment of the Attempt to Promote Public Good through Private Interest, . • . . $14 \overline{9}$

(c) Effects on Energy and Enterprise, . . . . 151

(d) Universal Brotherhood, . . . . . . . 153

\section{CHAPTER III. HALF TRUTHS}

1. Probleus of Life, . . . . . . . . 155

(a) Empirical Knowledge, . . . . . . . 155

(b) Hasty Generalisation, . . . . . . . 158

(c) Experience and Practicability, . • . . . 159

2. The Mechanism of Society, . . . . . . 161

(a) The Growth of Economic Science, . . . . 161

(b) Popular Misunderstandings, . . . . . 163

(c) Miscalculation by Experts, . . . . . . 165

3. Particular Aims, . . . . . . . . 167

(a) Cheap Food, . . . . . . . . . 167

(b) The English Yeomanry, . . . . . . . 171

(c) Utopias, . . . . . . . . . . . . 174

\section{PART III. PERSONAL DUTY}

CHAPTER I. CHRISTIAN CHARACTER

1. Self-Dedication . . . . . . . . . 176

(a) The Influence of Individuals on Society, . • • 176

(b) Enthusiasm and Self-Sacrifice,. . . . . 178

(c) The Divine Life Manifested in Place and Time, . 180

(d) The Gospel as a Spiritual Force, . . . . 181

2. Pergonal Service . . . . . . . . 183

(a) Positive Guidance, . . . . . . . . . 183

(b) The Restraint of Passion . . . . . . . 184

(c) Diligence in Business, . . . . . . . 186

(d) Power of Restraining Passion, . . . . . . 188 
3. The Responsibility of Trusteeship . . . $\quad 190$

(a) The Earth is the Lord's, . . . . . . 190

(b) The Duties of Investors, . . . . . . . . 191

(c) The Obligations of the Wealthy, . . . . $\quad . \quad 193$

(d) Recklessness about Wealth, . . . . . . . 194

CHAPTER II. SECULARISED CHRISTIANITY

1. Avowedly Christian Socialism . $\quad$. $\quad$. 198

(a) Philanthropic Aims, . . . . . . . . 198

(b) United Action, . . . . . . . . . . 199

(c) Double Allegiance, . . . . . . . . 200

2. Mundane Theocracies . . . . . . 202

(a) The Reform of Society, . . . . . . . 202

(b) Temporary Needs, . . . . . . . . 204

(c) The Sentiment of Brotherhood, . . . . 206

(d) The Supremacy of Christian Law, . . . . 208

3. Non-Christian Methods of Reform . . . . 211

(a) Transferring Responsibility, . . . . . . 211

(b) Abstinence from Things as Evil in Themselves, . 214

(c) Agitation against Evil, . . . . . . . . $\quad$. 216

\section{CHAPTER III. THE CHRISTIANITY OF CHRIST}

(a) Christ as a Preacher, . . . . . . 218

(b) Christ's Habitual Practice, . . . . . $\quad$. 220

(c) The Christian Commission, . • . . . . 223

BIBLIOGRAPHY, • • . . . . . . 225

INDEX, • • • . • • • • • • 229 


\section{-}




\title{
CHRISTIANITY AND SOCIAL QUESTIONS
}

\author{
PART I \\ WORLD-WIDE INFLUENCES
}

\section{CHAPTER I}

\section{PHISICAL CONDITIONS}

\section{Conditions of Animal Life}

Is the solution of every social problem many forces are at work, and it is not easy to say at any particular time or place which are the most important. High personal enthusiasms carry men away at times of national excitement; while laws and social conrentions seem to cast the men of one country into the same mould, and to stamp them as absolutely distinct from the people of other lands. At all erents, we may feel that there are some forces which are operative in all times and in all parts of the globe; whatever particular cases of progress or of porerty we mar be considering, it is alwars wise to take account of the fact that mon is an animal, and that the needs and greeds of animal life are in the background, eren when they are reiled from us by the usages of cirilisation. Te may begin by considering Man as an animal, and discussing the main conditions which affect his life, as well as that of other animals.

(a) The human race, like all other groups of the animal 
kingdom, has the power of increasing with great rapidity; there are indeed so many hostile forces which make for the destruction of life, that it is only because of this vigorous reproductive power that any one type of animal life can permanently survive. The destruction of young herring is enormous; they have to contend against a multitude of enemies, and a very small change in the balance of forces may easily extinguish a species in a particular habitat. The wastage of animal life is enormous, and there is need that it should be constantly replenished. If Man had not had, like other animals, a power of rapid multiplication, it seems unlikely that he could have survived, and spread, and adapted himself to life in every part of the globe. Considering how little protection he has, and how feeble his natural means of attack and defence, it is extraordinary that he should have held his own at all against the other inhabitants of the jungle. The power of rapid reproduction, under favourable conditions, is very great; population may double itself in five-and-twenty years; and hence, as we see, Man has been able to hold his own against and subdue the other forms of animal life.

While this reproductive power has been essential to human survival in the conflict with beasts and reptiles, it has also involved Man in a struggle with inanimate nature. In regions where Man is content to subsist on what nature affords, and exercises his skill in hunting or fishing, it is clear that a growth in the numbers of a tribe will soon render it increasingly difficult for them to obtain sufficient sustenance. Hunters who find that a rival tribe is encroaching on the available game are forced to fight, and they can only hope to retain access to a sufficient food supply by exterminating their foes. It is equally, though not so obviously, true, that when man settles down to improve the natural provision for his needs by tillage, he enters on a constant struggle with nature in a new form. Malthus made a careful collection of evidence as to the character and 
intensity of this struggle, and formulated the one great economic law which has been reached by induction-population tends to increase more rapidly than the means of subsistence tend to increase. Since it was first announced, there has been much discussion as to the most accurate way of stating this principle $;^{1}$ but as a summary of facts in regard to the physical conditions of human life on the globe it remains unassailable; it gives a fundamental explanation of much of the misery and suffering in the world. Since man, like other animals, tends to increase in number faster than the means of subsistence tend to increase, the scourge of poverty, with its accompaniment of starvation and disease, has been brought into operation again and again, as a positive check, and has ruthlessly reduced the population within the limits of the existing food supply. In some stages of society, the ravages of war and pestilence and famine are frequent and effective, but other causes are steadily at work to keep down the numbers in communities which are not subject to occasional devastation. Malthus noted that the weakest lives are those which succumb most quickly, and that a high rate of infant mortality is a mark which indicates the intensity of the pressure of increasing population on the means of subsistence.

(b) The seriousness of the conditions under which human life is maintained becomes apparent when we remember that all food, and most of the materials for clothing and shelter, are drawn from the surface of the earth, so that there are inevitable limits to the supply of the necessaries of life. There is, of course, a limitation of area, and we can calculate the extent of the surface of the globe which it would be possible to cultivate. Cultivation, too, is carried on in accordance with what is called the law of diminishing returns from land. This, like the principle of population, is a statement of observed fact, which came to be noticed

1 'The Statement of the Malthusian Principle,' in Macmillan's Magazine, December 1883. 
in England and to be formulated in the early part of the nineteenth century. In any community where no improvement in the arts of life is taking place, additional supplies of food can only be obtained at an increased rate of outlay: if double the ordinary labour is expended on the soil, it will produce more food; but it will produce less than double of what was obtained before. Where the additional supply can only be obtained by taking worse and less favourably situated land into cultivation, there will obviously be a diminished rate of return; and the same principle holds good where labour is applied with greater assiduity in the cultivation of land already under tillage. Hence it seems at first sight as if the struggle for existence must necessarily go on with increasing intensity ; population tends to increase on the one hand, while, on the ether, there appears to be a greater difficulty in meeting the simplest requirements of human life.

In the beginning of last century, when the operation of these principles began to be generally recognised, there was in many quarters a sense of hopelessness in regard to social improvement, since it seemed that there were physical tendencies which must inevitably force man down to a more sordid and squalid existence. There was a widespread danger that the acceptancc of these economic doctrines would paralyse all philanthropic effort, and the ' dismal science' seemed to cut away the ground for any hope of permanent amelioration. Every proposal for bettering the condition of the poor was waived aside as a mere temporary alleviation which might do harm in the long run. It was feared that the raising of wages in any industry would only give opportunity for the growth of additional numbers, and that the food which was requisite for these numbers could only be wrung from the soil with more strenuous effort. This appalling prospect is not merely suggested by temporary congestion, but is foreshadowed by principles which are in operation in all parts 
of the world, so that there seems to be ample reason for pessimism.

\section{The Progress of Man}

It is well to face the issue quite clearly, and to bear in mind these underlying physical conditions of human existence on the globe; but we need not give way to despair when we remember that, though Man is an animal, he is not merely an animal, since he is rational; he is not merely the plaything of blind forces, but he has powers of intelligence and will, which enable him to modify these forces, and thus to suspend the operation of the principles which seem to forebode inevitable evil. From this point of view we can see the problems in another light.

(a) The law of diminishing returns from land holds good for any state of society which is stationary so far as the arts of life are concerned : there is no region where progress in the arts is steady and continuous, and there are some countries where the same practices and methods have been maintained for centuries. The art of tillage was prosecuted with great success in Egypt under the Pharaohs, and long ages ago in India; but for many centuries past there had been little if any change, until it came about under the influence of British occupation. In England there was little improvement from the twelfth to the sixteenth century. Taking the world as a whole, and excluding the last century and a half of rapid change, we may say that a stationary condition in the agricultural arts has been the normal state of affairs, and that therefore the law of diminishing returns has been in almost constant and very general operation. Still, improvement in the art has taken place from time to time; and whenever such improvement is introduced, the operation of the law of diminishing returns is suspended. The very meaning of improved methods is that an increased result can be obtained 
with less outlay than before. An improved system of cultivation means, that by the application of increased skill better results are secured. In the Tudor times the practice of alternating pasture and arable husbandry was a great improvement on the old customary management; while the rotation of crops was introduced with similar advantages in the eighteenth century. Increased knowledge of methods of organising labour is equally important. From a very early time Man discovered the advantages of cooperation in agriculture; it is the employment, not of an individual, but of a family or a village working together. The maintenance of a similar agricultural system, which all take their part in carrying out, is the foundation of the village community; a definite system was perpetuated through the Middle Ages on manorial estates, and in the common field cultivation. Unless such a system can be itself changed for the better, from time to time, it may prove an obstacle to further progress. Every improvement in the management of an estate or the organisation of husbandry has facilitated the securing of better results with less outlay. Increased knowledge may also show how to make a permanent improvement which will save annual outlay, as the system of subsoil draining has done. Owing to the increase of skill, a far larger return per acre is obtained from the English soil than was possible in the thirteenth century; while great districts, which could not then be cultivated at all, are now yielding valuable crops. The drudgery in hours of labour per acre must be very much smaller than it was in the thirteenth century, while the return far exceeds anything that the mediæval agriculturist dreamed of. $\mathrm{He}$ was content with four or five times the seed, ${ }^{1}$ and sometimes had to put up with three; while the farmer to-day expects a return of twelve to fifteen times the corn he has sowed. It is obvious that the

1 Maitland, Domesday Book and Beyond, p. 438 ; J. E. T. Rogers, Agrtculture and Prices, i. p. 51. 
progress of human skill has shown itself capable of suspending the law of diminishing returns.

Improved knowledge of the conditions of tillage is not the only form of skill which is effective in suspending the pressure of population in the means of subsistence. Improved manufacturing skill, and increased facilities for procuring the comforts of life and instruments and means of cultivation, have a similar effect. The development of industry and of commerce gives a stimulus to the increase of cultivation, while this in turn affords an opportunity for industrial development. All kinds of material progress react upon each other.

An enormous heritage of skill and knowledge has been amassed and is being steadily increased; so that Man is infinitely better equipped to-day than he was in the time of the Pharaohs, for carrying on the effort to master Nature, and render her his servant. In a highly organised society, where the inhabitants act as a disciplined army, the struggle for subsistence can be carried on under the most advantageous conditions.

(b) Man has the power of learning, better and better, how to deal with the world in which he lives; it is also possible for him to learn to master himself and to restrain his own animal passions. The tendency for population to increase faster than the means of subsistence increase is not an uncontrollable physical impulse that works remorselessly. A preventive check is introduced by any one who exercises self-restraint and defers marriage till he is able to maintain a family, so that the increase of numbers need not bring about an increased pressure. The important thing is that the increase of subsistence shall come first, and that the increase of population shall follow. In any community where diligence in working is general, and men do not attempt to set up house till they have the ability and opportunity of earning a living, the pressure of population is not felt as an evil. Those who ignore the 
possibility of cultivating self-control have made Malthusian doctrine an excuse for advocating practices which are inconsistent with private virtue as well as with public wellbeing. Malthus himself held that the preventive check of deferred marriage-which is not only consistent with morality, but is the dictate of ordinary prudence-would, if generally adopted, bring about a gradual progress of society in numbers without any fear of a diminution in comfort. Just as the progress of man in knowledge suspends the operation of the law of diminishing returns, so the diffusion of better personal morality would suffice to prevent the tendency to increase and multiply from being an evil.

Indeed, so far from regarding a large population as a thing in itself to be dreaded, we should recognise that it is one of the marks of a prosperous community. So long as the population are actively employed and well nourished, every addition to the numbers is an accession of strength. If a population is sparse and scattered, there may be difficulty in organising adequate defences. During the seventeenth century in London, this matter presented itself as a practical question: the Civil Wars had unsettled society, harvests had been bad and food dear, a terrible plague had swept over the town and numbers had lost their lives. The nation, and especially the City, seemed to be defenceless for want of men, and continental quarrels were threatening. As a matter of fact, London was shortly afterwards exposed to the risk of bombardment by the Dutch. More men were wanted that industry might revive and flourish, and a deep anxiety was felt that the numbers should increase rapidly, and that populousness should be maintained. No nation can maintain its independence, still less can it exercise a decided and increasing influence in the world, unless it has a growing population; and in districts where the population is large, industry can be effectively organised, and the average standard of comfort may be very high. A large population in a growing 
community is a source of strength; on the other hand, there may be a redundant population in a country where the total numbers are not large and the density is not great. When there is a high degree of self-mastery, a redundant population need not come into existence ; and where rapid progress is going on, there is reason to hope that if it does come into existence, it will before long be absorbed in useful oceupations.

\section{Prospects of Further Advance}

When we recognise that Man is not merely an animal, but a rational animal, we may cease to regard the doctrine of Malthus with dismay, as if it told of irresistible forces under which the human race is being inevitably crushed. It is clear that Man, by the exercise of will and reason, which result in the raising of character and the growth of improved organisation, is able to suspend the operation of these physical tendencies, and to keep them from being mischievous. In this way we may see that the best prospect for keeping the evils at bay and for raising human life to a higher level, lies, not so much in the amelioration of material conditions, as in the raising of character and the improvement of organisation. This was the point on which Dr. Chalmers insisted in the agitation he led in 1817 for 'the extinction of pauperism '; ${ }^{1}$ we must still look in this direction for the secret of permanent prosperity.

(a) Ample evidence may be adduced which will serve to confirm this view; but, on the other hand, it is clear that the amelioration of material conditions does not in itself afford any prospect of permanent relief. If a greatly increased area of land were brought into cultivation, so that more food was available for a community, an opportunity would be available for all the inhabitants to live on a higher plane of comfort; but if the inhabitants generally,

1 Works, xxi. p. 247. 
or even a small portion of them, had no effective desire to adopt a new and better standard of comfort, the opportunity would be thrown away; in a few years there would only be a much larger number living at the old level. This appears to account for the fact which Mill pointed out ${ }^{1}$ as so terribly disappointing, that the enormously increased power over nature, which has come with the age of invention, has to such a large extent resulted merely in the increase of numbers who are living on the limit of subsistence, and only obtain a bare minimum of the requisites for human life. On the other hand, it seems to be true that if degeneration of character and dislocation or destruction of organisation diminish the productive power of a community, the pressure on means of subsistence will come into active operation even when population is not increasing. Redundancy may arise in connection with a decline of civilisation-this seems to have been one of the features of the decay of the Roman province of Britain. In the struggle with Nature a well-disciplined army may steadily advance, but if it becomes disorganised there can only be a harassing and ineffective guerilla warfare. The terrible retrogression of Western and Southern Europe in consequence of the barbarian invasions is an abiding illustration of the misery which may be brought about when a bighly organised industrial and commercial society is disintegrated.

(b) These considerations may give us a clue in regard to another far-reaching question, for they help us to note the forms of organisation which have most inherent vitality and are least exposed to shocks from without and decay within. The societies in which the best type of personal character is formed and maintained may be expected to have the most permanent success; the secret of the strength of any community does not lie merely in productive or military power.

' J. S. Mill, Political Economy (ed. Ashley), Book rv. vi. 2, p. 751. 
In all social organisation, for agricultural or industrial purposes, there must necessarily be some directing power, and there must also be subordination. Even in the most primitive forms of organised society there can be no complete independence. The doctrine of Locke as to a state of nature in which each man enjoyed complete liberty as a right ${ }^{1}$ is a mere figment of the imagination, though it served as a basis for the doctrines of the French Revolution and the Constitution of the United States. In all organised society there must be subordination; and the work of directing energies has been carried out by means of compulsion ; discipline has been needed to train men to work at the right thing, and to keep them working at it for the proper time. The discipline which fits a man for being a useful member of the community is essential to the continuance of well-ordered society ; and though it interferes with his liberty, it helps to make a better man of him. The discipline which man may exercise on the lower animals is an instructive illustration. Sir Percy Fitzpatrick insists that the rigorous training to which he submitted his favourite dog ${ }^{2}$ was amply justified, since it made it possible for the dog to be the trusted friend and companion of man. A large proportion of the human race are so lacking in foresight and perseverance that they would fritter away their lives in idleness unless they were subjected to compulsion. This has been the principle on which all the great civilisations of antiquity acted, but the system of compulsory slavery they adopted was defective, as it gave so little opportunity for the individual human being to develop his higher qualities. In so far as free labour can be introduced, and the principle of reward, which appeals to free men, is substituted for the principle of compulsion, there is an attraction and a stimulus for the individual to do his best and to improve his position; and this introduces 
elements of healthy personal ambition. In spite of all the limitations which it imposes, the modern community, with its principle of reward and its facilities for freedom of movement, gives far more opportunity for each individual to cherish and give effect to wholesome personal ambitions, than has ever been the case before. This has become possible because the free labourer is to a much greater extent self-disciplined, and can be trusted to carry on his work as it ought to be done, and when it ought to be done, much more confidently than is the case with slaves who need to be under constant supervision.

There is then a possible danger in the very completeness of organisation; it may guard so perfectly against waste of every kind, that there may be no opportunity for the individual to exercise responsibility, and thus to grow in intelligence and character. This appears to have been a fundamental defect in the marvellous agricultural and industrial communities which the Jesuits built up in the seventeenth and eighteenth centuries, out of most unpromising materials, in Paraguay. ${ }^{1}$ The natives became highly skilled in many industries, but they were so admirably drilled, and so docile in conforming to the drill, that no opportunity was given them for showing initiative or acquiring force of character. When the directing and controlling powers were withdrawn, the whole system appears to have collapsed. It is only by giving men some opportunities of leisure, and of acquiring some property of their own, that they can rise to their responsibility, and by developing a power of self-discipline, justify the trust which has been reposed in them.

The fostering the power of self-discipline is the thing to be aimed at in all education, and to be taken into account in all the institutions of the State which are formative of character. The claim of the undisciplined to have liberty to do as they like must result in mere anarchy ; independ-

I Southey, History of Brazil, ii. pp. 335, 343. 
ence and liberty appear to be incompatible with efficient organisation of any kind; thorough-going organisation seems to exclude liberty, but with the growth of selfdiscipline, organisation and independence become compatible. The liberty of self-disciplined men is the goal to be aimed at, and those societies have most inherent vitality which are bearing this steadily in mind.

\section{Common Sense and Christianity}

The true character of the struggle for subsistence, as it occurs in actual life, is only understood when we take account not only of the physical tendencies which affect Man-as an animal-but also of the possibilities opened up by his rational powers. The present situation need not force us to despair; but it is so serious as to give rise to great anxiety. There are such masses of human beings who live a merely animal existence, with no opportunities of anything better. The long tale of woe from savage lands seems to be hardly so hopeless as the failures of civilisation to remove the degradation which disfigures progressive communities. Though the pressure of population on the means of subsistence may be kept at bay, there is a constant danger that lassitude and indolence may bring it into more active operation at any time. There are, as it seems to me, three distinct habits of mind with which different people view the conditions in regard to man's place and possibilities in the world, and each of these mental attitudes will be associated with a corresponding feeling in regard to the Christian religion.

Anarchists altogether repudiate the diagnosis given above of the fundamental reason for the misery and poverty in existing society ; they deny that the misery in the world is due to the tendencies and conditions of man's life as an animal, and refer it instead to the greed of men, and the social conventions by which the strong have obtained the 
power to oppress the weak. ${ }^{1}$ Some few of those who take this view may hold that Christianity is essentially antagonistic to the existing order, and that it will give approval to their programme $;^{2}$ but anarchists generally are inclined to think that Christianity has had its chance and has failed; they regard the Christian Church as an institution of society which has been on the side of the oppressors and which must be destroyed. They are inclined to pin their faith to schemes for sweeping changes, with a light-hearted expectation that things cannot be worse and may be better; they pay little attention to the experience of the past, as they hope that it can have no applicability to the conditions of the new era.

There are also Pessimists, who are oppressed by the sordid actualities of life, and regard the possibilities of amelioration as so far off and so incalculable that they may be neglected altogether. Men of this type, who are comfortably off themselves, are sometimes inclined to close their eyes and ears to the trouble around them, and to acquiesce in it as inevitable. They may, however, feel the horror of the human struggle for subsistence intensely, as something that seems purposeless; and they refuse to attribute goodness to a Creator who has subjected the beings $\mathrm{He}$ has called into existence to such an ordeal. Two centuries ago, Natural Religion, with its recognition of the law and order amoug the heavenly bodies, appeared to be so obviously true, that it seemed to afford a foundation on which the structure of Revealed Religion could be based. But nowadays the thought of Nature is in many minds a serious obstacle to a belief in the dominance of wisdom and goodness in the Universe. Nature, 'red in tooth and claw,' the terrible waste of animal life, the degradation of human life through sordid struggles from which there is no reliefthese are things which alienate some men from any religious

1 Schmoller, Grundriss der allgcmeinen Volkswirtschaftslehre, i: 175.

2 See below, p. 208. 
belief, and tempt them to withdraw more and more from contact with grim realities. This habit of mind is apt to paralyse any efforts for the amelioration of mankind, and tends to check any form of practical philanthropy.

There is another mental attitude that is possible. Common sense inclines us to expect that the future will not be utterly and entirely different from the past, and that human life will continue to be affected by the tendencies which dominate over all merely animal life. On the other hand, sanguine temperaments recognise that there has been improvement, fitful and temporary and checkered, but yet real, at different times and places; and they are eager to give men fresh opportunities, and help in making the most of them. Persistent courage is needed to enable a man to face social problems with experience drawn from the past, and to deepen the conviction that it is worth while for him to devote himself to the service of man; but those who take this course will find that they are in close accord with Christian teaching. Christianity has no infallible nostrum to offer apart from human experience and effort; but it makes known an inexhaustible source of inspiration and courage for those who recognise the permanence of the existing physical conditions of human life, and are yet eager to set themselves to use the experience of the past so as to make the most of the possibilities which are inherent in the nature of man. It is possible to draw on inner experience and on the Christian sense of duty to support the resolutions and supplement the efforts of common sense.

(a) Common sense recognises that a discipline of the race has gone on during the past ages, and that, through the struggle for subsistence, Man has developed new powers and accumulated experience. Necessity has been the mother of invention; but it has been such a dire necessity, and so many have been crushed by it, that to religious minds the questions arise-has all this sordid and bitter suffering had an adequate result, and served a sufficient purpose ? 
can it be Justified ? can it be the work of God, and permitted by God? The same sort of difficulty pressed on the minds of holy men of old about their own personal lives. The world seemed all awry to them, when the wicked enjoyed such prosperity, and the servants of God suffered so severely. The Book of Job deals with the problem whether God could be thought of as good in view of the injustice of the world. But yet when they went into the Temple of God, they saw the end of those men, and they came to be reassured as to the existence and triumph of righteousness. Some of them could look back on the disappointments and miseries of their own lives, and feel, even within the limits of the mundane sphere, that good had been brought out of evil. In Christian times, with the larger view of human life and the clearer understanding of the part which suffering plays in the redemption of man, it has been less difficult for saints to trace God's hand in their own experience, however bitter. Men like St. Paul, who have found that all the trouble and disaster they endured personally, was, in fact, working for the glory of God in themselves personally and in the world around, have been able to cherish a hope that this will also be found to hold good in the world at large. The apostle looked out on animate existence and interpreted what he saw, in the light of what he had himself felt. St. Paul saw that the whole creation groaneth and travaileth in pain; he could not tell how this was to be set right, or what purpose it served; but with his personal experience of the wisdom and goodness of God in the way in which he himself had been led, he could cherish a confident belief for the justification of God's wisdom and goodness in the Universe at large. Personal Christian belief in the goodness of God reinforces the common-sense opinion that there is a purpose in the strain and stress of life, and that Man is being trained to rise to higher things. Along with this belief in the divine character of the discipline of the race under existing conditions, 
there may come the recognition of a divine element in all the factors through which this discipline is carried out. The physical conditions under which Man lives can be regarded as part of a divine order; the institutions of society, however they may have been misused, have grown up under God's providence and are not to be condemned as merely and wholly evil. All are working for a good that lies beyond the range of our vision, and it will be our wisdom to try to co-operate in their working.

(b) Common sense recognises the fact of improvement at different times and places, and hopes for indefinite progress ; but since there are peoples whose life has become stereotyped, and others whose condition is degraded, there is a temptation to limit the expectation of advance to certain peoples of mankind or to certain classes, and then to stigmatise all others as hopeless cases. Christianity comes in to enlarge and strengthen our hopes for the whole human race. The experiences and the records of saints in all ages go to show that the Gospel of the grace of God has a transforming power, and that it can reach and regenerate the most unworthy. St. Augustine found that it could deliver him from subjection to his passions; and the mission work of the Church, in penitentiaries and otherwise, is evidence that it has not lost its power of reaching and rescuing the outcasts of society. The power of hoping the best for the whole human race, even when the eyes are open to the cruelty and savagery of man, is a Christian grace, which widens and invigorates the most sanguine expectations we can form from a mere survey of the progress of the world.

(c) Christian faith gives a firmer basis to the belief in purpose and discipline; Christian hope enlarges ordinary anticipations of good ; and Christian charity has a specific quality of its own. There are plenty of calls for philanthropy of every sort. We recognise that in the progress of the world, localities may suffer, and in the advance of the 
race, individuals may be crushed. But even though we try to keep the happiness of the greatest number in the long run in view, we dare not forget the undying worth of each individual man and woman. It is a duty of philanthropy to try to diminish their suffering, and this is especially incumbent on the Christian in view of our Lord's interpretation of duty to a neighbour. Any philanthropic work may be undertaken from a Christian motive, and there are many fellow-creatures who appeal to our pity as victims of sickness or as oppressed by man. The march of progress is relentless; it is useless to try to bolster up a decadent industry or to maintain a class of pauperised workers, who cannot hold their own independently. Wise philanthropy does its best to set a man on his feet, and aims at giving him such fresh opportunities that he shall be able to enter the battle again, so that he may lead a responsible life, and be a useful member of society. All this may be done from Christian motives; but Christian charity has a different aim and a wider application than organised philanthropy. Its chief concern is, not with the man's condition but with his character: the aim of Christian charity is to take the resentment and the listlessness out of the hearts of the unfortunate. The scope of Christian charity may also be wider than that of mere philanthropy. Worldly wisdom may condemn many men and women as hopeless cases, when Christian charity is inspired to give them another chance. A touch of personal sympathy will call forth the best in human disposition and character; there is far less room for bitterness or recklessness in the mind of a man who knows that a friend is trying to bear his burden. The giving of money which is not felt to be an expression of real sympathy or a personal sacrifice may relieve physical suffering, but it has no healing influence of its own; it may be received as a right, and prove an encouragement to idleness. Real sympathy with and selfsacrifice for the sake of another-even when they cannot be 
expressed in forms that give relief to physical sufferingare the qualities that bring the service of Man into cl osest resemblance to the work of Christ.

\section{Christian Philosophy of Life}

(a) By taking a wider and deeper view than that of common sense, Christianity can claim to set forth a philosophy of life which helps to solve the apparent contradictions that seem so puzzling. It takes account of the whole of life-of inner experience as well as of the impressions we get from observing the course of affairs : it gauges the advantages and disadvantages of any change by their effect upon the inner life ; this standard cannot be applied at any moment with precision, but it is less misleading than any external standard, for it offers a safeguard against the mistake of attaching supreme importance to one or other of the secondary objects which men set before themselves, and are inclined to follow exclusively.

Among such secondary aims are the ideals of good order on the one hand, and of independence on the other; both are good, but at first it seems that they are irreconcilable, and that good order can only be secured by crushing independence. But this is not so ; by the cultivation of selfdiscipline it is possible to combine the advantages of a wellregulated community with those of independence, and this is the Christian conception of liberty.

Again, there is disagreement between those who wish to realise their aims at once and those who look to the future. The prodigal is eager for leave to use what comes to hand as he chooses now, while the economic man would have everything utilised with reference to future production. But unless a man has opportunities to misuse, he cannot learn to put things to their best use : the boy who never goes into the water cannot learn to swim. In attempting to put present opportunities to their best purpose, there is 
the best education of character, and the formation of the sense of responsibility is a grand result, even if it is attained by some apparent waste of time or money.

Once more there is a recurring difference between those who think of the greatest happiness of the greatest number and those who resent the sacrifice of individual lives for distant and impersonal advantages. Christian charity strives so to mollify the course of progress that it shall not ruin or degrade individual character. We need some living guidance to help us to thread our way among the respective claims of regularity and independence, of the present and the future, of the individual and the mass; and Christianity so far takes account of each, and holds the balance between them, that it may guard us against the danger of giving exaggerated attention to any of these objects.

(b) Christianity may also claim to be eminently practical. The elevation of human character is of supreme importance for keeping the pressure of external conditions from becoming more intense, and it is the special mission of Christianity to deal with men-not in the mass-but personally and individually. The characteristic doctrine which our Lord preached was the truth of God's fatherly care over each one of his creatures, and the sacraments give abiding expression to the fact that Christ's promises are pledged to each single member of the Church individually. And so, in advocating the duties of personal self-discipline and personal self-sacrifice, Christianity is advocating the most effective remedy for social evils of every kind, and one that can be brought into play, directly and immediately, by each man and woman within a larger or narrower circle. The Church may co-operate with the State in attempts to benefit the masses; but the specific work of the Church is that of moulding personal character and influencing personal lives. It is thus that Christian influence may be brought to bear most immediately, so as to permeate society as a whole. 


\section{CHAPTER II}

\section{RACIAL DIFFERENCES}

\section{The Defects of the Lower Races}

THE most striking contrasts in economic condition between various parts of the world are associated with differences of race. These are doubtless chiefly due to the conditions of climate and soil; for even if racial differences arise from inherent physical or mental characteristics, they are rendered more marked by environment; certainly they are of first-rate importance. There are white men's countries, where the white races can live and perpetuate themselves, and be at their best; there are other regions where the white races deteriorate, or where they cannot make permanent homes at all, while the black races flourish greatly. The differences are very deep seated : underneath the veneer of Western civilisation, which men of the yellow and black races can readily adopt, the natural proclivities may often remain, to break out unexpectedly when occasion offers. We may get some insight into the special temperaments and habits of various races from a consideration of the manner in which different groups of men have carried on the struggle for existence. At first sight it is not perfectly easy to justify the distinction which is commonly drawn between the higher and the lower races. Taken man for man, and as individuals, the noble savage is likely to be a much more efficient animal than the civilised man. His senses are keener, and his powers of endurance are very great; he has many kinds of highly developed skill. But 
even when all this is taken into account, we feel that certain races are higher, because they have a common stock of accumulated experience of many kinds, and each individual can draw, to a larger or smaller extent, on this heritage, so as to enjoy an unearned increment in addition to the fruits of his personal effort. The work of civilisation has been the building up of a great body of knowledge and of organised activity; the civilised man is able to dominate, not because of his qualities, but because he can draw upon the resources of civilisation and bring them to bear on the problem that confronts him. His advantage does not lie in what he is individually; it arises from the fact that he has had the privilege of entering into the fruit of other men's labours. The savage is inferior, because he is incapable of contributing to or participating in the heritage of accumulated experience. He is lacking in the capacity for being organised. In spite of the remarkable acuteness of his senses, he has defects which have prevented the native races of Africa and America from building up such civilisations as flourished in the ancient world and as are maintained by the white races in the present day.

(a) For one thing, the North American Indian has very little power of accumulation; he practically lives from hand to mouth. The power of looking forward and making preparations for emergencies is almost wanting altogether ; it seems as if he was deficient in a power of imagination, and in the faculty of vividly forecasting circumstances that are bound to arise. At all events, the primitive communism which exists in such tribes is a decided obstacle to any accumulation. It is difficult for all alike to agree upon providing for the future, or entering on any undertaking which will only afterwards become useful-such as clearing ground for tillage; and any one man who sets about a task of the kind would reap but little advantage, as the thriftless members of the tribe would demand and obtain a share of the sustenance which any tribesman possessed. Under 
these circumstances there is little room for surprise that there should be so much recklessness in consuming resources, and that the power of accumulation is hardly developed at all ; but it may be noted that this defect, while it interferes with material progress, is not necessarily either vicious or degraded. The determination to hang together, and share and share alike, is in itself well worthy of admiration; the great poverty of these peoples-and of some of the Celtic folk in Scotland and Ireland who present similar traitsis compatible with habitual generosity and gracious manners. But whether it arises from their virtues or their defects, the lack of the habit of accumulation accounts to a very large extent for their failure to make progress in civilisation.

This is one of the great landmarks in material progress. When the power of accumulation has been brought into play, and reserves of wealth exist, the community is relieved from the worst of anxieties, as they have the means of tiding over a bad season without serious distress. But the possession of reserve supplies opens up fresh opportunities of advance, and it is one of the outward and visible signs of a prosperous community. It is possible to commence great undertakings-such as the making of roads and embanking against the sea-which are carried on for a succession of years ; and it is also possible to provide implements which render labour more effective, or to introduce permanent improvements of a labour-saving character. The substitution of a bridge for a ferry, or of a stone or iron bridge for one of wood, provides a more lasting advantage to the community, but such works cannot be undertaken unless an accumulation of wealth is available for the purpose. The laying down of roads and railways, the introduction of machinery of every kind, and the advantages in the way of labour-saving which follow, all serve to illustrate the importance of the accumulation of wealth in the community, since none of these things can be available when every one 
lives from hand to mouth. It is hardly necessary to add that, under these circumstances, there is little likelihood of progress in science or literature or art. Opportunities for leisure are apt to be frittered away in idleness, unless there is some stimulus to employ them wisely.

(b) Another defect which seriously interferes with material progress is the difficulty which some tribes have of taking regularly and systematically to the practice of exchange. The Indians on the Oneida Reservation have difficulty in understanding a medium of exchange : one of them may have got a ball of wax, which he wishes to exchange for a blanket, and he tries to find a dealer who owns a blanket and will take his wax for it; he does not sell the wax for money and buy the blanket with the proceeds. So long as this sort of direct barter goes on, there can be no accurate adjustment of the bargain; it is only when an easily divisible medium is available that there can be a measure of value which is approximately correct at the time. Exchange will hardly be a part of the ordinary life of a community unless there is some recognised medium for buying and selling; and, without habitual and constant exchange, division of labour cannot be carried very far. It is needless to insist on the importance of this principle in bringing about the organisation of labour, and the specialisation of function, so as to secure the largest possible production at the smallest outlay. Habitual exchange is involved in the whole structure of any community which can manage to provide expert training for engineers or doctors. The growth of science and the arts has not, so far as we see, been possible in communities where there was no room for specialisation of function, because the use of money and systematic reliance on exchange had not come into voguc.

(c) These defects in the habits of primitive peoples suffice to account for their having made so little progress in material wealth and in civilisation. It is not too much to say that 
the power of accumulation and the practice of exchange have been essential to the existence of highly organised society, and that without them it could neither have come into being nor be maintained. Hence it is not a little remarkable that these are the very features which have been specially attacked, either explicitly or by implication, by Karl Marx and his school. They are enthusiasts for creating a highly organised and complex society ; but they discard the conditions which have been pre-supposed in all civilisation as we know it. They hold that the accumulation of wealth by private persons is injurious, that Capital is the enemy, and that all the evils of our present system are due to the tyranny which the owners of capital are able to exercise. 'That capital must be destroyed before any thorough reorganisation can take place is,' according to Mr. Hyndman, 'certain.' I In order that capital may be prevented from rising into power again, after being once swept away, the opportunities and facilities which encourage the growth of capital must be checked. The existence of coined money, as a medium of exchange, supplies a material which is readily available for hoarding, and, according to Marx, it seems necessary that money should be abolished, in order to leave no room for the passion for gold.2 Similarly, the existence of the family as an institution, the love of offspring, and the desire to perpetuate a name have done much to foster the desire of accumulating - both money and lands in private hands; and Mr. Wells insists that 'the family of the private individual must vanish' 3 in the reorganised society of the future. It is quite likely that, in this way, the desire of accumulating in private hands would be rooted out; but it is not clear that the function which private accumulation has served in organised society could be replaced by collective foresight and corporate

1 Hyndman, Economics of Socialism, p. 247.

2 Das Capital, p. 113.

3 Wells, Socialism and the Family, p. 30. 
accumulation. Public capital would be required to maintain existing works of every kind, as well as to make any progress; and such capital could only be formed through the authoritative determination of the Government, not by the voluntary action of free citizens. ${ }^{1}$ To many persons the whole of this scheme seems dangerous in its method and retrograde in its probable results. The desire of accumulation and the facilities for exchange have been so intimately connected with the growth of organised society that it may not be possible to remove them and to retain any organised society at all. Mr. Hyndman fails to show that ' a destruction of the great means and instruments of making and distributing wealth' 2 would not be involved in the abolition of capital. In the later Roman Empire, where private capital became an object of attack, the entire destruction of society followed, with a deterioration in the arts of life, and an increase of misery and drudgery. So long as there were rich men to be plundered ${ }^{3}$ it was possible for the Roman Emperors to maintain the roads and other great public works; but after the barbarian invasions, when there were no private accumulations to bedrawn upon, these fell into decay. Our system of production is more sensitive to attack, since labour-saving machinery calls for rapid replacement; and if the productive power of the community were reduced, opportunities for enjoying leisure and pursuing culture of any sort could not be maintained. If private capital is to be regarded as the enemy, and the individual power of accumulation is checked, the community as a whole is likely to decay in material prosperity, as the Roman Empire decayed. Even if the growth of capital can be secured authoritatively instead of voluntarily, there would be a danger that the prevailing type of individual character would be lowered, in a community where opportunities and responsibilities were so much

1 See above, p. 11.

2 Hyndman, Economics of Socialism, p. 248.

3 Essay on Western Civilisation, i. p. 183. 
curtailed. ${ }^{1}$ It is unlikely that we can have things both ways, and retain all the advantages of organised society, while we stamp out the factors which have brought it into being. When we consider the condition of lands where the desire of accumulation has never been brought into play, and the state of families in England which are given over to improvidence, we may hesitate as to the wisdom of trying to destroy the desire of accumulation where it at present exists. It is surely wiser to recognise that this desire is a great economic force, and to set about directing it, and trying to correct and restrain its operation where that proves mischievous. ${ }^{2}$

\section{The Inter-Racial Struggle for Existence}

The struggle for existence, which arises from the pressure of population on the means of subsistence, has not been carried on in bygone days as a wholly unorganised war of all with all, such as is figured in Hobbes's State of Nature. Mankind has been grouped in clearly marked regiments and armies; tribe has warred against tribe, and race against race. Difficulties in regard to the means of subsistence have had much to do with the constant occurrence of savage war in Africa and among North American Indians, and the most striking race conflicts which occurred in European history were probably due to similar causes. But in whatever circumstances they may have taken their rise, the results of the barbarian invasions illustrate the fact that in racial conflicts the battle is not always to the strong;Goths, Vandals, Huns, Lombards, and Franks swept in turn over parts of the area of Roman civilisation, and in this great contest some races survived and continued, while others died out and disappeared. It is worth while to try and detect the secret of racial vitality in the struggle for existence, and to specify the qualities which render one 
race of man fit to survive in the contest, while another is crushed out and disappears.

(a) The power of self-adaptation to changed conditions seems to be of supreme importance in this connection. The invading barbarians were of migratory or semi-migratory habits, and as they showed themselves victorious they were called upon to adapt themselves to the conditions of settled life. But the circumstances under which they made this attempt were much affected by the strenuousness of the opposition which they encountered in different regions. In Spain and Italy and Gaul, the invaders could establish themselves as lords over conquered inhabitants; but in England, where the Romanised Britons were loath to submit to the invaders, the Teutonic army was compelled to settle down to work upon the conquered soil. In the areas which they conquered most easily, the barbarians failed to root themselves deeply, and the Latin races were able to reassert their predominance. On the other hand, the barbarians were able to adapt themselves to the conditions of settled life, and to cultivate the arts of peace in such a fashion that they could hold their ground, in those regions where the struggle had been most severe, and the Roman institutions had been practically swept away. At a later time, it is noticeable how the peoples of the north, who had shown such energy in the arts of war, and proved for a time the scourge of Western Europe, were unable to maintain their predominance when they adopted a new religion and discarded their militant life. Their vigour did not at once find a new direction under the changed conditions. Some races seem almost to have lost the power of adapting themselves to new conditions. People who have long enfoyed a high civilisation, which has continued to exist for ages and has given rise to elaborate institutions, are unwilling to cast their racial traditions aside, and to modify their habits of life in accordance with changed circumstances. The Hindu and the Chinaman are much less susceptible of 
new ideas, and much less ready to accept new modes of work, than the races who have little organisation of their own, and who are willing to take their places as hewers of wood and drawers of water in a newly created community. But unless a people has some power of adapting itself, it must disappear before the march of progress. The conditions of human life are not permanent anywhere; they alter from age to age; and races which cannot alter with them are bound to disappear. Regions, both in Assyria and in Central America, which were once occupied by vigorous populations, and which were the centres of active life, are desolate and barren; and the peoples who inhabjted them have left no living tradition, but are only known to us by the relics that survive.

(b) Another important advantage in the contest is connected with the virility of a race, and this is at all events closely associated with the tone of morality which prevails. Different experiments in family life-polygamy, polyandry, and the like-have been tried among different peoples and discarded. The monogamous family appears to afford the most healthy conditions for the upbringing of children; and the races which have adopted it and enforced it under legal, social, or religious sanctions, have succeeded in keeping their hold on the regions where they have settled, and have perpetuated themselves as powers in the world. On the other hand, irregular self-indulgence is the sign of a decadent race ; deliberate refusal to undertake the responsibilities and cares of family life may become a source of weakness, and lead to the extinction of some racial element in a community. These seem to be the principal causes of the decay and disappearance of races that were formerly powerful, but have long since ceased to exercise much influence in the world; and such symptoms must be taken into account in any attempt to forecast the future of races in the present day. With regard to the struggle for existence as it occurs among mankind, it is to be noticed 
that while the pressure has of course been felt by individuals in each race, the result has shown itself, not so much directly and in the increase of individual capacity, but rather in the establishment of the superiority and dominance of one race or another.

\section{The Contact of two Races on the same Soil}

During the last three centuries the problems connected with race have come into new prominence, owing to the facilities for inter-communication between distant regions which were opened up in the fifteenth century and which have been so extraordinarily increased in recent times. Throughout the Middle Ages the various races of mankind were each, for practical purposes, confined to a particular continent or region, and only came into occasional conflict with one another. The Chinaman and the Hindu, the African and the North American Indian, had no relations with the peoples of Europe, and the journeys of some travellers, such as Marco Polo, were but rare exceptions to the rule. So far as Europeans were engaged in a struggle with men of other race, they formed the long line of the battle between the Crescent and the Cross ; Islam presented a great barrier which stood between Europe and Asiatic or African peoples, and this proved for centuries to be almost as impassable as the Atlantic. Despite wars of consolidation and of aggression, the peoples of the European countries kept on the whole to their own lands, though the Scot was a noted exception. ${ }^{1}$ In mediæval as in ancient times, when different races occupied the same soil, the pride of race or of conquest served to define the relative positions of the two peoples, so that superiority and inferiority became an accepted fact, and there was very little friction, comparatively speaking, within the community. But the progress of maritime discovery and the organisation of

1 Dante, Parad., xix. 121. 
oceanic communication have entirely changed the situation. The flank of the Mahometan races was turned by the Portuguese, and Europeans established themselves as traders in the countries of the East; when they also succeeded in overthrowing the ancient civilisations of America, and in bringing the sources of mineral wealth under their control, the difficulty of obtaining sufficient labour for extractive industry led to the transportation of numbers of negroes to the New World. As the colonisation of distant regions has proceeded, and Europeans have attempted to develop the resources of distant countries, there has been a series of movements which has brought two or more distant races into close contact on the same soil. The mutual knowledge that has thus arisen has not always led to friendly relations ; incompatibilities of temperament and racial jealousies have made themselves felt during recent times in a way that was unknown in the ancient and mediæval world.

(a) A chief and recurring difficulty has been felt in regard to the possession of land. Tribes which lived by hunting or by pastoral pursuits do not make the fullest use of land that is fit for arable cultivation. The needs of the world as a whole seem to give us a standard as to the manner in which each part of the world's surface may be most fitly employed. It is at least plausible to argue that all land ought to be used in the fashion in which it can contribute best to the wants of the world, and that no one, not even a black man, has a right, for the sake of his own tastes and preferences, to divert it to a less productive use or to keep it relatively idle. This principle, whether sound or not, seems to be assumed by land reformers at home, and it is one that has commended itself to white settlers all over the world. They have failed to recognise the right of native races to wasteful occupation of valuable territory. The white races, both in America, Africa, and New Zealand, have been guilty of great high-handedness in giving effect 
to this principle, but it is at least to be remembered that there have been many cases where they have endeavoured to behave fairly, and where trouble has arisen through the failure to understand native law ${ }^{1}$ and commercial possession. The settler who had bought out one occupier, and imagined he had obtained the right to exclusive use, resented the intrusion of other natives whose interest in the land had, through ignorance and inadvertence, not been taken into account at the time of purchase; mutual recrimination has given occasion to savage attack, which has been met in turn by ruthless punishment. As new countries have been occupied by white men, the native races have been crowded out, through the constant encroachments of civilisation. The limitations imposed upon them have rendered it impossible for black men or red men to obtain the means of subsistence in accordance with their traditional modes of life, by hunting, pasturage, or primitive cultivation; and the degradation and extinction of the native races has ensued. Some few have been able to survive, with a position and status that is wholly anomalous; they are only too likely to have lost the best features of their own race, in the effort to adapt themselves to be parts of a community which furnishes its quota to and receives resources from the commerce of the great world.

(b) Even greater difficulties have arisen with regard to labour. In the conditions of tropical countries, the arduous labour connected with mining or with cultivating the soil can be undertaken on much cheaper terms by black men, whose standard of comfort is low and who do not find the climate specially trying. There has been a temptation in all ages for a dominant race to procure this labour under compulsion. The mines and the public works of Egypt appear to have been the occasion of terrible oppression;

1 Many of those who have little sympathy with the main work of Christian missionaries would recognise the admirable help they have given in the understanding of native custom and usage. 
and some system of slave labour, or of forced labour, is likely to be in vogue wherever those who are developing a country depend for the actual work upon a native population. Slave labour is unwilling and costly, as involving much supervision; there is a distinct advantage when work can be assigned to free labourers who are stimulated by the hope of reward. But among savage peoples the hope of reward furnishes a somewhat fitful stimulus that cannot be counted upon to ensure regular and long-continued work. If high wages are given to attract men, they are enabled to obtain what they regard as affluence very quickly, and then to enjoy a protracted period of idleness. Under these circumstances, there are very great advantages in the system of indentured labour. A contract is made for a period of time, and payment is deferred till the time is completed; the master can count on labour for a definite and extended period, and the labourer finds himself in possession of a substantial reward, and with the opportunity of improving his position when the term of service has come to an end. Where long contracts are made with natives of the country, it is often necessary that the men should be kept in closed compounds, like those of the De Beers Company at Kimberley; as they are always apt to break the contract, and to escape from the monotony of labour to their own homes. But with labour imported from a distance this difficulty does not occur : the homes of the Indian coolies who are employed in British Guiana ${ }^{1}$ are so far distant that there is no temptation to attempt to return to them before the contract is up, and the coolies can, in consequence, be left to enjoy practical freedom in open compounds or scattered villages. It is comparatively easy to organise such Government supervision that the coolie immigrants shall be properly treated, and at the expiration of the contract each man is free either to return home, or to settle in the country where he has been working. In

1 Alleyne Ireland, Tropical Colonisation, p. 191. 
either case the accumulated payment will enable him to make a better start on his own account than he could ever have done if he had stayed at home. There seems to be more prospect of reaching a satisfactory solution of the labour problem in some such fashion, than of finding any means of reconciling the claims of two different races to the use of the same land.

\section{The Persistence of Racial Distinctions}

The contact of two very different races on the same soil cannot fail to have some effect on the characters of each. In many households and plantations in Virginia and throughout the South, the dependence of the black on the white called forth a sense of responsibility and solicitude on the part of the masters which was repaid by the devoted affection of their slaves. But none the less, the influence of slavery as an institution has been, on the whole, injurious to the character of the slaves and of the masters as well, and herein lie the real grounds for condemning it. The masters are in danger of becoming more domineering and tyrannical, the slaves of sinking into a condition of helpless lethargy. Where the division of race coincides with a recognised difference of status, an inseparable barrier is erected between the black and the white; but it seems possible to hope that under other conditions this need not be so. The imitative faculty is very strong; and the lower race may easily adopt many of the habits and practices of their social superiors, while the influence of a similar education may also tend to reduce the differences further and further in each successive generation. From this point of view, it appears that assimilation may go on so rapidly that, after a comparatively short time, racial distinctions would cease to have much importance and could be ignored.

It may be noticed in this connection that a process of 
assimilation is not likely to be entirely one-sided. If the higher race at times exercises an attractive influence over the lower, there are cases where those who deemed themselves stronger and more advanced have been absorbed by the people among whom they settled. Both in the time of Henry II. and in that of Cromwell, soldiers were planted on estates in Ireland with the view of anglicising that country, but their descendants have, in many cases, come to be merged in habit and feeling with those among whom they settled. It has been the revenge of the conquered people. If the higher race is to exercise its full influence in elevating a subject people to its own level, there must be no inter-marriage or amalgamation, as this results in the blending of the two.

(a) Whether this process of fusion is beneficial or not, there is no reason to apprehend that assimilation and amalgamation are proceeding very fast, and that differences of race are at all likely to be suppressed in the near future, so that they need not be taken into account in the world at large. Even in the area of the United States of America, where a deliberate attempt has been made to avoid any formal recognition of racial distinctions, they continue to be very marked. The Constitution of the United States recognises the rights of man as man; and the political system of the country has been framed on such lines that it might be possible for men of all nations, peoples, and languages to take their part in directing the system. But though racial differences have been left out of sight, they have not been really suppressed, and they are constantly reasserting themselves. There is a black belt where the negro population is very large. The horror felt throughout the South, of the vigorous animal passions of the black, is symptomatic of a constant anxiety, and of a dread of the results which would ensue if white dominance were seriously disputed. But apart from the colour question altogether, the minor differences of race preserve them- 
selves to some extent. Numerous immigrants arrive each year from all parts of Europe ; and although it is the pride of the American that these extraneous elements are rapidly assimilated, their existence as distinct factors in the community is not altogether lost. There are considerable districts where the political power is in German, Irish, or Italian hands; and racial affinities are so far preserved as to give occasional rise to incidents that have an international bearing. ${ }^{1}$ It has even been remarked that a racial stratification can be traced through the whole system. The representatives of the oldest settlers of the English race have, on the whole, kept their position at the top, and form some fifteen millions out of the population of seventy-five millions. Next in importance and activity are the Germans, with an occasional Jewish strain, the Irish, and the Swedes; and then the Latin races and the various forms of coloured population. It is not clear that these racial layers are likely to preserve their relative importance; the population of English extraction does not multiply so rapidly as the races with a different standard of comfort. The elements ot which American society consists are gradually changing their relative proportions, and it is at least possible that through these modifications the economic, moral, and political condition of the country may be greatly affected. Even in such a country as the United States, racial distinctions are extraordinarily persistent, and it is futile to attempt to ignore them altogether.

(b) The British Empire has grown up in very different conditions and under the influence of other ideas; considerable care has been taken to recognise racial distinctions, and assimilation and amalgamation have never been regarded as an ideal to be aimed at. British sentiment on this subject was determined when the British Empire was still being planted and only beginning to grow. The

1 Among these may be mentioned the Fenian raid on Canada, and the blackmailing organised by the Italian Mafia. 
parliamentary union of England and Scotland marks a conscious abandonment of the attempts which had hitherto been in vogue for bringing about the assimilation of all the subjects of the Crown to one particular type. The Parliament of Great Britain has recognised a Scottish national life, which is distinct in law and religion from that of England. As the British Empire has grown, there has been an increasing readiness to give free play to the maintenance of separate national or tribal traditions within the Empire. 'There has been a constant and serious attempt to understand and administer the native law and custom of different subject peoples. Care has been taken, as far as possible, to maintain existing institutions in old countries, and in newly settled areas encouragement has been given, from the time of Lord Durham onwards, ${ }^{1}$ to the growth of colonial nationalism. English statesmanship has aimed at giving scope for the development of many different types, not at forcing all to adopt the same model. The builders of the British Empire have had in view the preservation of the institutions of many different races and peoples within the limits of one political system.

'The cosmopolitan, who is detached from any one country and poses as a citizen of the world, is inclined to despise the prejudices of race and the narrowness of patriotism, and to regard them as merely mischievous; but it takes all sorts to make the world; the life of humanity would not be enriched if all these minor differences were suppressed. Looking back on the history of the past, we may feel that it has been by giving free play to its special aptitude that each race has made its contribution to civilisation. The history of Greece was not a repetition of that of Egypt nor a mere anticipation of that of Rome; each led its independent life and contributed its special quota of useful arts, or of

1 Lord Durham's 'Report on the Affairs of British North America' (Parliamentary Papers, 1839, xvii. 5) was epoch-making, from the manner in which it laid down inproved lines of colonial policy. 
philosophy, or of law to the common stock of mankind. The backward races of the present day have each their own aptitudes, and points of mental habit or manual skill, in which they are better equipped than Europeans. Each of them might, if suitable opportunities were afforded, have some contribution to make to the life of the world that no other race can make so well. The world is likely to be poorer if all are reduced to a similar level; but the unrestrained play of economic forces appears to be conducing to this result. The special aptitudes of particular peoples are in danger of being effaced by the crushing force of economic cosmopolitanism. In these days of rapid communication, it is possible to treat the world as a single market for many purposes of production and distribution, and to aim at breaking down all the barriers which hinder commodities from being circulated by the force of this one great stream to every part of the globe. Economic cosmopolitanism is a fascinating policy, for it seems to open the way for all countries to co-operate for each other's good, but it may also bring new rivalries into operation $;^{1}$ indeed, in so far as this conception has been realised, the backward races have been brought into direct competition with peoples that are economically more advanced. Primitive peoples, in all their economic weakness, are forced into a struggle to hold their own against the economically strong ; their agriculture has to give way, since their land is required to grow materials and food that have a high value in the distant industrial communities, and it is developed by men with concessions from distant powers. Besides this, machine-made goods are introduced into their markets, and

1 Prof. Nicholson has shown that Adam Smith's doctrine did not really have the cosmopolitan character usually ascribed to it (A Project of Empire, p. 10). In 1891, when I gave a presidential address to the Economic Section of the British Association at Cardiff on 'Nationalism and Cosmopolitanism in Economics' (Statistical Society's Journal, liv. p. 644), I did not realise as clearly as I do now, the grave evils which are inevitably connected with cosmopolitanism, or the practicability of treating the Empire as an economic unit. 
their artisans are exposed to the stress of the struggle between hand-work and machinery. On one side or the other, the economic life of primitive communities is attacked, as they are drawn into the circle of the world's commerce ; they are often impoverished, and forced to feel the increasing strain of the struggle for subsistence.

India is the part of the British Empire where this economic cosmopolitanism has had free play, and there can be but little doubt that it has inflicted serious injury on the native manufactures. Fifty years ago India was celebrated for the excellence and artistic quality of the industrial arts, which had been gradually built up and traditionally maintained in that ancient civilisation. Cashmere shawls, Dacca muslins, and numerous forms of metal work in gold, silver, and brass had reached a high state of perfection. Half a century has sufficed to stamp out nearly the whole of them-with a distinct loss of artistic quality in the productions of the world, and therefore of the possibility of the further development of artistic production in the future. Though this change is to be regretted, it has probably ceased to be of much importance, so far as the trade relations of India with the rest of the world are concerned. The recent development of the jute industry has given India a much more valuable manufacture than she possessed before. But there is no reason to suppose that the progress of manufacturing has made much impression upon the country at large. ${ }^{1}$ Throughout India generally there is not much fluidity of labour, and the village is the economic unit; ${ }^{2}$ and, in so far as imported wares are taking the place of native manufactures, the village population is thrown back more and more upon the soil. There is a widespread impression in India that the population is becoming more impoverished, and the facts that the

1 Sir J. A. Bain's 'General Report of the Census of India, 1891,' in Parliamentary Papers, 1893-94, lxiv. p. 595.

2 E. A. Gait, 'General Report on the Census of India, 1901,' in Parliamentary Papers, 1904, lxiv. p. 227. 
area under crop is being enlarged, ${ }^{1}$ and that a landless class is increasing in many villages, ${ }^{2}$ seem to indicate that the village industrial population has been forced to revert to agriculture for the means of subsistence; there is some reason to believe that the pressure of population upon the soil has become more serious, and that there is increased difficulty in wringing from the land the means of purchasing cheaper goods. England has made splendid efforts for the welfare of the people of India, by establishing peace throughout the length and breadth of the land, and limiting the excesses of the arbitrary rule of native princes; all this is of little avail if, after saving the population from the blind forces of pillage and aggression, we have handed them over to be the prey of the blind force of industrial competition. The manner in which the population of India has been suddenly exposed to the full force of competition in the markets of the world gives rise to grave anxiety. Peaceful commerce can claim its victims as well as war, and it exercises an insidious action which affects the whole fabric of society.

\section{The Christian Claim of Fair Play for Native Races}

(a) There is at the present time a strong sentiment in favour of according a generous treatment to native races, but there is a constant danger that the temptation for the strong to oppress the weak may break out in some form or another. The restraints of humanitarian feeling have not been sufficiently strong to prevent civilised men from engaging in cruelties on which we look back with shame, and it must be remembered that there are extraordinary possibilities of self-deception in this matter. The Spaniards really believed that they were conferring a benefit by bringing so much of Central and Southern America within

1 Less than half of the additional area is irrigated land. E. G. Colvin, 'Effects of British Rule in India' in Nineteenth Century, Sept. 1909, p. 534.

2 Morison, Industrial Organisation of an Indian Province, p. 190. 
the circle of Christendom, and it is equally possible to imagine that native races are gainers by being brought within the influence of the whirlpool of the commerce of the world. Apart altogether from such self-deception, however, the ruthless disregard of the welfare of native races, which leads to their degradation and extermination, may be carried on almost as a duty, and at any rate with a clear conscience, by those who are in actual contact with natives and know their ways. The pioneer in a distant land, who is trying to develop the resources of a country so that it shall come into line with modern conceptions of its possibilities, is apt to regard the aborigines as mere obstacles in the path of progress. He heartily endorses Clough's rendering of the sixth commandment:

'Thou shalt not kill, but need'st not strive Officiously to keep alive.'

From his point of view there is little or nothing to be made of the natives, and the sooner they succumb before the march of economic progress, and are crowded out in the struggle for subsistence, the better.

Philanthropists at home who resent this doctrine as materialistic, and desire to give the native races a chance of sharing in the best that man knows of culture, and above all of religion, have not always been able to apply a suitable corrective. The cosmopolitan philanthropist is not acquainted with the savage, through actual contact with him, and does not know the danger of his unrestrained passions, and the impracticability of his conceptions of property. The cosmopolitan philanthropists, who have ignored the reality of racial distinctions, and who have insisted that the savage should be treated as if he were something that he is not, have been the worst enemies of those they profess to defend. They have sometimes failed to realise how much of native institutions could be advantageously retained; and they have not recognised the extent to 
which discipline, especially the discipline of work, may be needed, before individuals can be trusted with the privileges which are the birthright of men in civilised societies.

The sense of racial superiority is a fundamental difficulty, since it is apt to distort the judgment of vigorous men on these matters. The consciousness of great achievement, and of great capacity, on the part of a race gives rise to a desire to make the most of opportunities; and when it is coupled with a sense of destiny, the will to live becomes an ambition to exercise a wider and deeper influence in the world. This sense of racial superiority inclines men to make a very one-sided estimate of what should be done to take fair account of the claims of less favoured peoples. It is quite as likely, if not more likely, to come into play among a people who are used to self-government under democratic forms, as to arise under a personal government. Pride of race is often infurious to the people who cherish it, since it is apt to render them less adaptable, ${ }^{1}$ and its persistence and growth is a cause of irritation, which endangers the peace of the world, ${ }^{2}$ but the most obvious evils it entails are seen in the treatment of native races. It thus appears that neither rational intelligence nor philanthropic sentiment, nor the sense of dignity of a great people, avails to correct the baneful influence which Western civilisation has exercised on so many of the peoples with which it has been brought into contact.

1 The people of China and the Hindus are cases in point. See above, p. 28.

2 War, with its devastating effects on the human race, is such a terrible scourge, and lies so entirely within the control of human beings, that there is a widely diffused sentiment in favour of trying to do away with it altogether. Many of the causes of war, as it has existed in the past, have come to an end; the cost of war among civilised nations is so great that men are less likely to run lightly into war; but so long as there are marked differences of race, there is a possibility that a trivial occasion may give rise to wars which aim at racial expansion. The pride of race is able to clothe racial aggression as a virtue, and to represent racial expansion as a necessity. War remains as a permanent menace to civilisation, and the great armaments show how widespread is the apprehension. Readiness to have recourse to war, in modern tines, is rooted in the pride of race, which exists among the Western nations, and has been stimulated into new life in the East by the successes of the Japanese. 
(b) The best hope of avoiding this shame in the future lies in being in earnest in adopting and giving effect to the truths embodied in Christian morality. There must be, first of all, the recognition of Right as absolute and supreme, apart from all considerations of worldly prosperity or racial dominance ; we cannot see the matter aright if we base our decisions on experience in the past or forecasts of the future, so far as we can penetrate. We must endeavour to look at these struggles with dispassionate eyes, in the light of a wisdom that cometh from above. The Christian belief that God has made of one blood all races of the earth, and that we dare not destroy fellow-creatures whom $\mathrm{He}$ has endowed with such possibilities merely because they stand in our way, is the only foundation on which a wise and generous method of dealing with the native races can be established. It involves the acknowledgment of a power that is greater than man's, and the sense that our duty lies not in doing what we, with all our limitations, think wise, but in trying to do what $\mathrm{He}$, with infinite knowledge, wills. The hearty recognition of this divine sovereignty, as supreme, will help us to be on our guard against the self-deceptions and the selfishness which have led to cruelty and wrong. This religious element was very plainly present at the laying of the foundations of the British Empire in Elizabethan and Stuart times, and though its operation has been restricted and obscured by political causes and commercial considerations, it has never been wholly forgotten. At any rate it is worth noticing in this connection, that in spite of the arrogance of manner which so many peoples feel and resent in the Englishman, his racial pride has been really kept in check. All through his national history the Englishman has been ready to learn from other peoples, and has adopted the habits and practices which he saw were worth imitating. Englishmen have been curiously unwilling to increase the bounds of their dominion and the responsibilities of rule: Cromwell was 
prepared to abandon our claims in the East and much of our footing on the American continent ; and during the last century, when there was such an enormous expansion of English rule, the tale of the lost possessions of England was increased by the abandonment of some positions of great importance for maintaining maritime supremacy. ${ }^{1}$ The readiness with which the mother country yields in cases of territorial disputes to foreign powers has done much to strain the loyalty both of Canada and of Australia. By the foreigner this complacence is often interpreted as a sign of the weakness and cowardice of a mere bully. But those who believe that the traditional spirit of Englishmen is not dead, prefer to interpret it as a sign of acceptance of the idea of Right as absolute in political affairs, and of a willingness to make some sacrifice of racial interest, in order to give it effect.

(c) The effort to give all backward peoples a fair chance and a real opportunity appears to be a specifically Christian work. It is an attempt to rescue those who are being crushed in the remorseless struggle for existence. ${ }^{2}$ It involves a certain self-sacrifice, a refraining from making use, to their fullest extent, of the opportunities which lie within our reach, in order to set about it at all. No one can be expected to throw himself heartily into the task unless he is inspired by a confident hope that it is possible to make something of very unpromising material ; there is need of patience not to be weary in well doing. Much time must elapse before the remnants of a tribal system and of native institutions can find an appropriate place in a growing and developing community; still more is required for the exercise of such discipline that the black man, set free from the restraints of traditional custom, may become so selfdisciplined as to become a useful member of civilised society. No cut-and-dried maxims will serve to solve

1 W. F. Lord, The Lost Possessions of England.

2 See above, p. 18. 
difficulties which occur in different and constantly changing circumstances ; but it is a task in which Christian citizens can take a part through administrative measures, and Christian missionaries have also work to do in connection with it. The State may be at pains to put down what is obviously injurious, such as the supplying of native races with alcoholic liquors, and can insist on the strict observance of agreements that have been made with them. Besides this, the missionary can hold up such ideals of right, and exercise such careful discipline over those who come under his influence, that the converts may learn to make good use of the opportunities secured to them by government. The primary aim of the State is mundane, in ordering the affairs of this world ; and the primary aim of the Church is spiritual, in the salvation of souls; but both powers can co-operate. The white man's burden is the task of training the native races, and modifying their habits and institutions, so that they shall be able to live a wholesome life among the other peoples of the world, and that any individuals, who are capable of appreciating the best gifts of civilisation, should have the opportunity of sharing in them. This is a task which has been very specially laid upon the men of the British Empire; and it is by our capacity for rising to this duty, and doing it successfully-as successfully as the Romans did in their day-that our worthiness for our place in the world will ultimately be judged. 


\section{CHAPTER III}

\section{CIVIL AUTHORITY}

\section{The Enforcing of Right and Justice}

THE consideration of the disgrace which has occasionally sullied the reputation of civilised peoples, on account of their conduct towards native races, has led us to recognise the importance of a conception of right and of justice as something which is in a sense absolute, since it is superior to all mere interests and ambitions. Throughout the world at large, there is no agency by which the carrying out of what is right, apart altogether from the convenience and aims of separate races, can be secured with certainty. During the Middle Ages, the Papacy attempted to play this part ; but its claims to authority have been discredited, and it has little influence with such powers as Russia, Great Britain, and the United States. Under these circumstances, the maintenance of right between nations can only be secured by agreements and treaties; each of the powers is primarily concerned with the interests of a particular race or nation, and there is a frequent temptation for the contracting parties to set aside the demands of international morality, and, if occasion offers, to repudiate an agreement that has ceased to be advantageous.

Within each realm it is also important to maintain the conception of right as something absolute, and independent of the particular utilities and disutilities which vary from moment to moment. This conception of right may be habitually enforced within each separate country; the 
government provides an organ through which right can be authoritatively maintained and justice done, without fear or favour. The sphere within which each such separate authority is exercised may be spoken of as a Realm or a State. The powers that be, within each State, are ordained by God for the punishment of evildoers and the praise of them that do well; and social problems in each separate country assume a very different aspect, according to the manner in which the rulers interpret the obligations of this trust.

(a) There is an extensive sphere in which it is possible for the State to draw a clear distinction between right and wrong, and to brand and punish what is wrong. In so doing, the State habitually exercises powers which do not belong to any individual, and cannot be conferred by any assemblages of individuals. No man has a right to take away the life of a fellow-creature. The extreme need of a man, who, when drowning, had 'presence of mind enough' to act in self-defence and knock another from a plank which seemed insufficient for them both, lies outside the sphere of rights altogether. At a supreme moment he has made a decision in his own favour, and he lives as a man whose conduct needs justification; while others who have taken the generous line in similar circumstances are regarded as heroes. The State claims a right to take away life by capital punishment, and claims a right to sacrifice the lives of many thousands by engaging in war. Again, no individual has a right to deprive another of his property, without giving a quid pro quo; but the very essence of taxation is that it involves the sacrifice of money on the part of individuals for the sake of objects which do not benefit them directly, or even of which they disapproveas members of a Peace Society disapprove of the maintenance of armaments. The State assumes the position of a super-man, in endeavouring to enforce right and to punish crime among its citizens, and does what no individual has the right to do. 
(b) This superhuman element in the life of the Statethe duty of enforcing justice, as a divine thing, and without respect of persons-degenerates into an arbitrary tyranny unless it is exercised under a sense of responsibility. The resolute purpose to do what is right and put down what is wrong, leaves no room for the play of caprice; it may be strengthened by the sense of a tradition of just rule, which ought to be maintained, and of the duty of handing down this tradition untarnished as a heritage for posterity. But the strongest safeguard against the temptation which besets rulers to exercise their powers as they like at the moment, and even for their own personal advantage, is afforded by the theistic belief that those who rule are responsible to God for the manner in which they discharge their duty. This doctrine has been maintained since Apostolic times in the Christian Church ; it is at all events a means of keeping before the minds of men the idea of something that is to be enforced because it is right. The conception of government as a power and trust to be exercised by kings on behalf of God is a comparatively simple one in monarchies, since the personal responsibility of the ruler for the manner in which he discharges his duty among the people committed to his care can hardly be denied by any person who makes a profession of Christianity. It is most important that the same sense of trusteeship and of duty on the part of the governmentto be indifferent and to punish wrongdoers of any classshould be maintained under democratic rule, and that all the citizens, who in any way take part in directing the policy of the country or framing legislative measures, should exercise their powers under a sense of responsibility and not in a light-hearted spirit. Their powers are very varied; some merely give a vote, and others take a much more active part in political life; but whatever share a man may have in the government of the countrywhether occasional or constant-he will do his political 
duty better if he tries to do it under a sense of responsibility to God.

(c) When the superhuman element in civil authority is thus recognised, and the responsibility of exercising it is seen in its religious aspect, a clearer view may be obtained as to the nature of civil obedience. Submission to an authority which he feels he ought to respect is not inconsistent with the dignity of a freeman, even in cases where the particular exercise of authority may seem to him personally to be unnecessary or unwise. But submission to mere force and to mere caprice is a mark of subservience. Respect for authority is the cohesive force which keeps the mechanism of society from working without friction; any action which impedes and defies civil authority makes for the disintegration of the community. Bad citizens are prepared to fall in with the mandates of the State, but only so far as these further their personal interests or carry out their own wishes, and they submit to that which they dislike because they have not the power to resent or to resist; they have no conception of obedience as a duty to be done, or respect for the State as an authority over them. The citizen who has a respect for the law as law, will show that respect by carrying out the commands of the State even when they do not fall in with his own views. If he is conscientiously unable to do what is enjoined, he can yet show respect to the law by accepting the penalty without resentment. John Stubbe, who, when he had just been deprived of his right hand, used his left to lead a cheer for Queen Elizabeth, showed that, however seditious the 'Gaping Gulf' might have appeared, he was himself thoroughly loyal to the Queen's Majesty and her rule. This is the spirit which holds a community together and enables it to achieve a great victory against overwhelming odds.

In England this conception of government has been steadily maintained; civil obedience has been constantly, though not universally, recognised as a duty to be rendered 
from religious motives. The high conception of legislative and administrative responsibility, as something to be exercised in God's name, is kept before the minds of the public by the Coronation Service, as well as by the constant recital of prayers for the King, and for divine guidance for Parliament. Closely associated with the recognition of divine authority is the belief in the supremacy of the morally right, as something which ought to be enforced among men; this has been fundamental in the political life of Britain, however the citizens may have differed as to the means of detecting the right, or the manner in which it should be enforced. The charge of hypocrisy, which is so frequently brought against British policy, is an indirect testimony to the prominence of the expression of this belief ; since hypocrisy is the tribute which vice pays to virtue. Those who hold that a love of dispassionate justice, and a belief in the possibility of exercising it, is a genuine feature of British character, will at least be in earnest in seeking to foster it and to render it more thorough and effective.

(d) Whether it is strengthened by religious sentiment or maintains itself without such support, this principle gives us a clue to the essential difference between good government and bad. The powers of the State are so great, and its influence in all departments of life is so far reaching, that the character of the government of a country is by far the most important factor in all the social problems which arise within its area. The sense of public spirit, and of duty to the public, is the salt which helps to keep every form of civic life free from corruption. Respect for the administration of justice cannot be maintained unless the public believe that crimes against person and property are punished without fear or favour, and in all alike. In the ancient régime, with a privileged noblesse, this principle was boldly disregarded. Public spirit and a sense of public duty must permeate the administration of the affairs of 
State, or corruption will enter both in the modes of collecting revenue and in the expenditure of public funds. The importance of a high sense of public duty is confirmed when we recognise how much it contributes to the prosperity of a country in its economic sense. For a man to be secured by authority in the enfoyment of the fruits of his enterprise and of his labour, and to be secured in the possession of that to which he is entitled under the laws of the State, is the corner-stone of all industrial prosperity. ${ }^{1}$

In civilised communities, where the use of money is constant and habitual, the necessity of a high sense of rectitude in regard to the medium of exchange has become obvious, though monarchs were long in discovering that it was a public duty to maintain the standard of the coinage, and not to attempt, in consequence of temporary necessities, to tamper with the purity of the circulating medium issued under the authority of the State: that lesson was finally impressed upon Englishmen in the time of Edward vI. and Elizabeth. It is even more important that the duty of fulfilling contracts should be carefully maintaincd in modern times, when so much use is made of the power of national credit. Recent research has demonstrated that Charles II. had exceptional excuses for breaking faith with the national creditors, ${ }^{2}$ but the shame of the Stop of the Exchequer will never be forgotten. Much sorrowful experience had to be gained before the conditions under which credit can be maintained came to be clearly understood; but Englishmen gained this experience during the eighteenth century; in their hands credit became the great instrument by means of which Great Britain was able to bring such vast resources to bear in the struggle with Napoleon. Dependence on credit has come to be part of our political, as well as of our commercial, system; but

1 See below, p. 33.

2 W. A. Shaw, 'The Beginnings of the National Debt,' in Owens College Historical Essays, p. 400 . 
credit is so sensitive, that the whole fabric might be jeopardised by some apparently trivial disregard of its obligations on the part of the State. The moneyed interest could hardly pass unscathed through such a succession of campaigns as have been directed for the last half century against the landed interest. The claims of the dead hand are not altogether easy to Justify in either case ; and the repudiation of a debt, or of interest, will always be a temptation to those who do not keep scrupulously to the opinion that a breach of the plighted word is not to be thought of because it is wrong.

\section{The Utilitarian State}

The influence of a high ideal of public duty, in ensuring a healthy condition in all departments of political life, is so insensible that it is possible to ignore it altogether, and to regard the State as a purely utilitarian institution which looks after the interests of the citizens jointly and severally. This conception suffices for some purposes. It is possible to regard the maintenance of the Army and Navy as in the interest of all the citizens, since all are defended against attacks from without; and also to treat the punishment of crime and the maintenance of police as things that are in the interest of all honest men. This view of the State and society is most plausible in its economic aspects, though even here it is inadequate $;^{1}$ but there are some grounds for maintaining that the good of the whole is best attained by giving free play to individual self-interest. Bastiat and othor writers have been prepared to believe in a prearranged harmony by which the self-secking of each worked out for the benefit of all; under these circumstances laisser faire could be regarded as the best basis for the well-being of the community. It may be urged that the conflict of interests is merely apparent, and that the

I See bolow, p. 88. 
separate interests so far cancel one another out and correct each other that the good of the community as a whole emerges, naturally and unconsciously, by giving perfectly free play to personal ambitions and tastes and proclivities. There is some apparent fustification for this theory, when the material wealth of the community is all that is in view ; and when the form of self-assertion, taken for granted, is that of the competition of business men of a similar type with one another. In this shape free play for self-interest was regarded as an axiom by the Manchester School ; but it was only plausible, because these writers assumed that self-interest was more or less enlightened. In so far as any man prefers to be comfortable in the present at all hazards, whether he has to beg, borrow, or steal, or even to live on his wife's earningis-he cannot be allowed to carry out his own views of what he likes without detriment to the community. The indulgence of the personal desire for immediate enjoyment is apt to distract from a consideration of the well-being of the community. As individual lives are shorter than the life of the community, the aggregate of personal interest, at any one time, can never be identical with that of the community as a whole. The more men are trained to take a far-sighted and a large view of their business interests, the more nearly will their conscious selfinterest and personal estimate of utility and disutility coincide with the welfare of the community. ${ }^{1}$ This possibility of reconciliation does not arise from the fact that the individual is free to assert himself as he likes, but is due to his being so trained intellectually that he is capable of exercising self-restraint. It is the development of intelligence, the power of looking far ahead and far afield, that enables him to bring himself into line with the good of the community without conscious effort. Even in the economic sphere it is clear that the good of the whole is secured, not by giving free play to actual interests, but

\footnotetext{
1 See below, p. 95.
} 
through the restraint that is laid upon them. And in the larger questions of politics it is also necessary that the calculation of personal interest should be corrected by other considerations.

(a) 'The willingness to make habitual sacrifices of personal convenience and personal advantage for the public benefit is what we mean by public spirit; it is the very antithesis of the Utilitarianism which seems, to the casual visitor to the United States, to satisfy the American citizen. While the patriotic sentiment and humanitarian sentiment are strong in that country, the sense of public spirit, and therefore of a duty to make trivial sacrifices on behalf of the State, seems to be little developed. It is difficult to avoid forming the opinion that political life appears to be regarded in America as the mere weighing of larger and smaller interests against each other, and presents little attraction to men of cultivation and leisure. The conception of government as trusteeship for the community as a whole, and of administrative life as helping in the discharge of a great public trust, is curiously lacking in America ; but political authority seems to be treated as if it were nothing more than a power of giving effect to or mediating between the claims of the interests of particular areas or particular sections of the community. ${ }^{1}$ Each of these may be represented as an element which is essential to the good of the whole ; each may be attended to in turn, so that an approximation to the good of the whole can be secured by the administration-and it may be a very successful approximation. But from this point of view, which seems to be adopted by many Americans, there can be no sense of public duty to take part in civic affairs; the competing interests can be trusted to look after themselves in turn. The political boss may be a well-meaning cynic

1 In England, Land, Capital, and Iabour have each claimed in turn to be the elenent of paramount importance, the interests of which should be favoured for the sake of the welfare of the community as a whole. 
who believes that it is impossible to retain really able men in the service of the State unless it is made worth their while, and holds that it is necessary to find indirect methods of tempting men of great capacity to throw their energies into public life, since the taxpayer would never consent to pay salaries which would be adequate to reward them. This is the principle which has been systematically followed by Tammany Hall, so as to secure great efficiency in municipal government, but at extraordinary expense to the ratepayers. Where political life is conducted in this fashion, there can be little sense of obligation to meet the requirements of the State, and no habitual readiness to incur a sacrifice for it-no stigma of any kind will attach to the ' tax-dodger,' as he is merely defeating the machinations of some other interest. Large interests must often be anxious to influence the administration of justice; and attempts to bring monetary influence to bear on judicial decisions, both in State Courts and in the interpretation of the Constitution, need cause no surprise. The interests of the members of the community are, to a very large extent, in favour of the maintenance of a measure of law and order, but there are occasions, in America as in other places, where it is for a man's private interest to have the law set aside. The failure to recognise a sense of duty, altogether apart from interest, in political life, seems to account for the small amount of public spirit among the wealthy classes in the United States, and for the lack of ambition to enter on public life.

(b) Though for many purposes the utilitarian State seems to secure excellent results, and a community may flourish in strength and wealth and maintain a high standard of culture and comfort under its control, occasions yet arise when political action is taken that lies outside the ordinary canons and that cannot be justified on purely utilitarian grounds. These offer an unconscious testimony to the truth that there is a right, and a duty to the State, which 
is above all considerations of interest. The enormous sacrifices which were made on each side during the American Civil War sufficed to show how deeply rooted this spirit is, even though it does not find expression regularly and habitually through the machinery of State.

Something similar is to be observed in the appeals to a 'higher law' which appear to be recognised as a sufficient ground for setting aside the ordinary course of justice. The recognition of a right, on the part of a private person, to take the law into his or her own hands and to punish a criminal, is a testimony to the belief in a justice supreme, above all human institutions; but in so far as this supreme justice is brought into operation, not through the institutions of society but apart from them, the ordinary administrative institutions are unnecessarily discredited, and the course, which the higher justice takes, is in danger of being spasmodic and ill-considered. The racial animosities in the South have led men, again and again, to assert the right to exercise rough-and-ready criminal justice, on grave suspicion, but without formal proof, by Lynch Law. When the administration of the affairs of State is not consciously and continuously penetrated by the sense of duty, it is hardly possible to see in what way outbursts of righteous indignation can be brought under rational control.

(c) Mr. Roosevelt has expressed himself in a way which shows that he does not recognise the validity of any absolute right or sense of justice in international affairs. He holds up Englishmen as giving an example which his countrymen should follow, inasmuch as he believes that Englishmen are for their country under any circumstances, and are eager to secure its interests whether right or wrong. ${ }^{l}$ But this is the sort of praise which Englishmen would disclaim, and which they might even resent as insulting. It is part of the national pride of the Englishman that he 
believes that his country has fought to enforce the right, without regard to national gain or loss; and he has even been ready to attribute this same disinterestedness to Americans themselves. It is only on the supposition that both parties are agreed in desiring a settlement which is just and right, that any Englishman would agree to settle political disputes by arbitration. ${ }^{1}$ If arbitration is to be a mere bargaining, in which each nation tries to win its case at any price, it can hardly lead to such a settlement of any dispute as will be permanent. There is less finality about a decision obtained through successful 'bluff,' and the skilful manipulating of the cards in the game, than by the arbitrament of war. Much is said in America about the desirability of introducing arbitration as a means of settling international disputes; but the experience of the Alabama award, and of the means by which it was obtained, ${ }^{2}$ have done much to render Englishmen unwilling to trust great issues to this method of settlement. If this mode of avoiding the horrors of war is to be effective, it must be clear that, in the statement of the issues as well as in the composition of the tribunal, both parties are willing to be fair, and are ready to give such full information as will lead, not merely to the triumph of their own case at the time, but to the realisation by peaceful means of what is right and fair.

(d) In contrast to what is familiar to him in his own country, the English traveller in the States is likely to be surprised at the attitude which is taken on the other side of the Atlantic towards civil authority, and the want of respect for it as maintaining and enforcing right between man and man. The very limited extent to which the conceptions of right and wrong, and of public spirit and public duty-apart from mere interests-enter into American political life is partly accounted for when we consider the

1 See below, p. 74.

2 J. Pope, Sir J. A. Macdonald, ii. p. 85-140. 
history of the country. The first settlers in New England had been strongly repelled by the forms by which the religious element in English political life had been exercised in the time of Charles I. Their strong assertion of the supremacy of the individual conscience was inconsistent with the admission of a divine sanction for existing civil authority, and religion was brought to bear by the Puritans to justify resistance; but they had little success in creating a new social order. The attempt in the New World to regulate the entire life of the community by a system of organisation devised for religious purposes was not a success ; and after the Congregational theocracies broke down, through the revulsion which was felt in regard to the treatment of the Salem witches in 1692, the pretension of exercising any religious influence on civil affairs disappeared. Religious conviction does not appear to be a powerful factor in public life either among the administrators or the citizens of the old Puritan States. Christian ordinances of every kind have ceased to play a prominent part in the life of the community throughout large districts of the country. According to Governor Rollin of New Hampshire, ${ }^{1}$ "The decline of the Christian religion, particularly in our rural communities, is a marked feature of the times, and steps should be taken to remedy it. . . . There are towns where no church bell sends forth its solemn sound from January to January; there are villages where children grow to manhood unchristened; there are communities where the dead are laid away without the benison of the name of the Christ, and where marriages are solemnised only by the Justice of the Peace.' This widespread neglect of religious ordinances is, in the Governor's opinion, bound to react upon civil life. 'Every good citizen knows,' he says, 'that when the restraining influences of religion are withdrawn from a community, its decay-moral, mental, and financial-is swift and sure.' Under these circumstances, it

1 Proclamation in Concord Evening Monitor, 6th April 1899. 
is clear that an influence which might do much to elevate its tone is not being effectively brought to bear on public life.

The constitutional doctrines which found favour in America were directly derived from the philosophy of Locke, and he avowedly based civil government on a convention made for mutual convenience; there was no room in his system for any authoritative claim to obedience in affairs of State, or for any assertion of right apart from the dictates of interest. The conception that persons and communities bartered a portion of their freedom for the greater advantages of combined life, was practically exemplified in the growth of the United States; where townships were federated into States, and States were at last, for mutual convenience and commercial purposes, federated into United States. Administration in the townships was always regarded as a burden for which remuneration was expected, and the little communities left very little freedom or initiative to those who undertook such office. The petty distrusts which show themselves in parochial politics, and the dread of rival interests, have affected the atmosphere in which the civil institutions of the North have grown up ; and there has been no influence, either religious or philosophical, to counteract these tendencies, and to keep alive or maintain the tradition of English public life. The difference of tone between political affairs in America and in Great Britain is not to be accounted for by the fact that the United States is a young country with no leisured class, but seems rather to be associated with the prevalence there of a cynical habit of mind, which is inconsistent with a sense of public obligation and with honourable ambition.

\section{Corruption and Decadence}

(a) The fact of the reality of right, and the supremacy of fustice as the dominant factor in political relations, is 
confirmed by noting the Nemesis which has overtaken politics, where this guiding principle has not been recognised, or where it has been very imperfectly acted upon. If civil authority is not based on a really firm foundation, there is constant danger of its being undermined altogether. Public and private interests are very closely intermingled; it is impossible to keep them absolutely apart. The administrator who is not carefully scrupulous and sensitive is sure to come under the accusation of merely acting for his own personal advantage, in disregard of the public good, and possibly to its injury. The personal and the public cannot indeed be severed; but there is all the difference between the man whose ambitions are realised through the public good and by doing public service well, and the man who is prepared, when opportunity offers, to treat public affairs as subservient to his personal gain. If he is willing to take the latter course, great opportunities of taking advantage of his position occur in connection with the granting of concessions to men of capital for enterprises either at home or abroad.

Lord Burleigh stands out in the Elizabethan age as a high example of scrupulous probity in this respect as well as in all other public affairs. The business of the State involves many transactions and much employment of labour; there are opportunities for men in any department to feather their own nests. But this sort of administrative corruption is rarely completely successful for any length of time, as the modes of checking and detecting such misconduct in the ordinary departments of Government are constantly being improved; and those who incur the suspicion of abusing places of trust are forced to relinquish them. Francis Bacon was compelled to give up the highest office in the State on grounds which do not seem to have constituted any stain on his personal honour ; but, even in that age, he had become an impossible person for the post he held. If corruption comes to affect public 
service generally, it is likely to undermine all respect for authority, and to endanger the stability of the system of government. The frequency of revolutions in France has been evidence of the slight hold which any of the governments has had upon the respect of the citizens; and interesting examples occur in English history as well. It seems extraordinary that a body of men, such as the majority in the Long Parliament, who had taken a lead in the demand for popular liberties and had succeeded in their struggle with the king, should have proved incapable of establishing a strong Republican government; but the corruption among them was notorious, and it was impossible that they should secure the respect of the country or obtain a long tenure of power. ${ }^{1}$ The opportunities offered for obtaining large estates out of Church or Crown property constituted a great temptation. Lenthal and other prominent members of Parliament showed so little power of resisting it that they incurred the scathing denunciations of Milton, and they had so completely forfeited public respect that it was easy for Cromwell to oust them altogether. Even under his rule, the government was not so conducted as to win the confidence of the country. The army, which he had created, and the navy, which had come under his control, enabled him to remodel the government of the country, and to procure a strong position with foreign powers; but he and his army were in the position of making their own estimate of their deserts, and rewarding themselves accordingly. There was no such self-denial as made it clear that they had the public good at heart, rather than their own advancement ; and there came to be increasing difficulty in obtaining contributions to the revenue required by a government under which a few individuals had notoriously sprung into wealth and power. The Protectorate, in its turn, was completely discredited; so 185.

1 Growth of English Industry and Commerce in Modern Times, pp. 181- 
that Monk and Clarendon met with little opposition when they set themselves to reintroduce the old constitution in Church and State. With all its defects, parliamentary government affords the opportunity for the public criticism of men and measures; and neither dishonest individuals, nor a corrupt system, can long maintain the tenure of power in the face of a public opinion which is healthy and sound. This is the ultimate tribunal by which men and institutions are tried.

(b) The preservation of a high tone of public opinion is the one effective safeguard for rescuing the State from the evils introduced by administrative corruption; the maintenance of high character affords us the best security that regard shall really be paid to the welfare of the public. It is certainly wise to be on the watch against opportunities for wrongdoing on the part of officials, though this may result in complication and fussiness over details; but it is as impossible for the body politic, as it is for the human body, to guard against the inroads of every possible disease germ; the best safeguard is in the maintenance of such a healthy condition that the attacks of disease can be thrown off. The tone of political life is elevated, or it is lowered, not so much by any one particular act, as by the whole spirit in which public affairs are conducted. It is possible for public business to be carried on either in a Christian or in an unchristian spirit. If Christian principle is to be successfully brought to bear on public life, it cannot be by mere occasional agitation for some particular measure-such as the freeing of slaves or the closing of public-houses-but by the constant effort to inspire all political action with Christian aims and motives. Every public leader does something to educate his party and modify its character for good or evil; the manner in which he puts forward his policy tends to affect the constituencies, and either to raise or lower the citizens in their fitness for taking a share in ruling the country and her destiny ; it is 
less by any particular achievement than by the influence of his career on the character of his countrymen that a great statesman serves his country best. Even if his policy is unsuccessful and his calculations fail, the man who so conducts the affairs of the realm as to ennoble the aims and clear the thoughts of his fellow-citizens is entitled to the highest admiration as a statesman. The best results, from this point of view, are likely to follow when the statesman appeals to the intelligence of those whom he wishes to influence, and sets them thinking. He quickens their intelligence, if he is not content to coin a phrase, and raise the party cry as a badge, but forces them to consider whether, under changed circumstances, the old cry has any meaning, and, if so, what that meaning is. A statesman can exercise a long-continued and national influence if he sets before the public a clear principle which can be applied in many directions, or a high ideal of the good of the community which embraces many subordinate aims and sets each in its due place of importance. The further he himself looks in time, and the wider the area of which he takes account, the better will he be able to help his countrymen to take farseeing views. The effort to present his policy in this fashion will have a chastening influence, as he must discard any exaggerated and hasty language, since it is offensive to the habits of careful reflection, which he is endeavouring to bring into play.

The statesman, whose primary appeal is to sentiment, does not do nearly so much to improve the character of the citizens who are influenced by his lead; it is true that generous sentiment is strengthened by finding expression in action, but it is impossible to sustain highly wrought feeling, as a steady and persistent force, in the same fashion as carefully thought out ideals may be maintained. A community whose sentiments are easily aroused in one direction or another-which oscillates between indignation at atrocities in Bulgaria, or elsewhere, and horror at armed 
intervention of any kind-can have no stability of purpose, and no persistent policy.

It is also to be noticed that ardent feeling is uncritical ; there is a danger that wholesome sentiments may be played upon by the unscrupulous advocates of unworthy causes. The appeal for justice may be urged as a cloak for spoliation and confiscation. Napoleon was able to shelter his schemes for aggrandisement under the plea of giving liberty to oppressed peoples. A war which is advocated on mere grounds of humanity, and which is not occasioned by a definite cause of quarrel between two nations, would be difficult to account for, if it were impossible to detect the active play of some selfish interest as the underlying motive.

More dangerous still is the course of the politician who merely appeals to the interests of his supporters. It is unnecessary to lay stress on these interests, if he is really advocating something that is in the interest of the whole community, the sacredness of national obligations and the importance of maintaining what the nation has guaranteed, as the case can be put more effectively on higher grounds. When prominence is habitually given in political discussions to the consideration of mere interest, it is generally because the interests of particular sections of the community are being kept in view, to the disregard of the interest of other sections and classes. Such a line of argument will easily degenerate into a mere appeal to selfishness. It tends to the cultivation on the part of a section or class of an exaggerated sense of its own importance in the life of the realm. The rivalry between the landed and moneyed interests, at the close of the seventeenth and beginning of the eighteenth centuries, had a most unwholesome influence on political life. The landed interest were jealous of the manner in which the moneyed interest escaped the burden of taxation, the moneyed interest resented the smallness of the share they possessed in the directing of public policy, and they endeavoured to 
remedy what they regarded as an infustice, by unscrupulous bribery. The advocacy of the claims of particular classes or sections of the community gives rise to jealousy; it has no suggestion to offer for any constructive policy; and, by creating increased irritation and mutual suspicion, it causes friction in every part of the mechanism of society. The adept in statescraft, who makes use of these instruments to play on the passions of the citizens, may succeed in carrying out the particular objects that he has in view at the time, but he is a curse to the country, since his influence tends to render the people less fit for the harmonious exercise of the privilege of self-government. For such corruption of public opinion on political affairs, when a people are thoroughly imbued with it, there seems to be no remedy; it is the most obvious symptom of political decadence. 


\section{PART II}

\section{NATIONAL ECONOMIC LIFE}

\section{CHAPTER I \\ THE FUNCTIONS OF GOVERNMENT \\ 1. Justice and Expediency}

(a) Although the enforcement of right is the supreme consideration in all matters of State, it can never be the only consideration; other points have to be taken into account as well. Justice is retrospective, and deals out punishment to brand a crime committed; in its simplest form it is merely retributive-an eye for an eye, a tooth for a tooth, and a life for a life. The plain man thinks it fair that the individual who has been guilty of wrong should be done by, as he did; and the simple exaction of an equivalent seems to meet the case. The crime has been done, the punishment has been inflicted, and the incident is closed. But there are many cases in which retribution cannot be exacted; the beggar who steals some one's watch cannot be deprived of his own watch in return, because he has none; and even in cases where simple retribution is possible, we may take a larger view, and desire to inflict punishment in such a form that it shall be a deterrent in the future, as well as retribution for the past. Experience shows that it is possible to devise forms of punishment which serve to be corrective, so that the same person will not be likely to commit the crime again; we may also try to make the punishment exemplary, so as to prevent other people from 
committing a similar offence. When such probabilities are taken into account, considerations of expediency are allowed to determine the form in which justice shall be enforced. Strict criminal justice lies between man and man; as concerned with retribution for the past, it can be precise and definite. But the probable effects on individual character cannot be estimated with any certainty; when we are trying to forecast the future, we cannot lay down any course as absolutely right, but only as expedient, so far as our reasonable anticipations go. The tendency of corrective punishments is to be less severe than the strict exaction of an equivalent would be ; they are intended to be warnings which the man shall take to heart himself, rather than the infliction of retribution; and justice in this case is tempered with mercy. On the other hand, exemplary punishments are apt to be more severe than a merely retributive punishment would be ; they are intended to strilice the imagination, and warn other people to be careful. The public may demand that a chauffeur who, through some very trivial carelessness with his car, is unfortunate enough to kill a child on a road, should suffer the extreme penalty for manslaughter, in order to teach other chauffeurs a salutary lesson. Corrective and exemplary punishments alike depart from the strict rule of retribution ; and in the case of exemplary punishments, the question is often raised whether it is just that an individual should be dealt with, not entirely on his own merits, but so that he is to some extent sacrificed for the good of society. The instinct of self-preservation justifies society in demanding the sacrifice of the lives of the citizens to repel the attacks of enemies; and the same instinct comes into play to demand some individual sacrifices for the sake of maintaining order and security at home. The important point is that there should be a real prospect of influencing the public effectively ; any appearance of vindictiveness, especially through the cruelty of the punishment, tends to make the 
criminal something of a hero, and weakens the respect for authority. The history of the Inquisition, in its efforts to stamp out heresy with the aid of the civil power, serves to illustrate the difficulty which attaches to exemplary punishments and prevents them from being really effective.

Even, then, in carrying out the work of the State in repressing crime, there are many points in regard to which different opinions may easily arise as to what is expedientwhat sort of punishment will suffice as a corrective, and when it is necessary to make an example. It is not easy to form a sound opinion as to what is wise, and therefore right, under any given circumstances; the evils of Lynch Law are that no attempt is made to exercise a wise discrimination, and that the punishment, when meant to be exemplary, is so likely to be vindictive. By relying on the ordinary machinery of the law, we at least render it less likely that the execution of justice shall be contaminated by a desire for private revenge. The duty of the judges is to exercise a considerable discretion in the punishments inflicted, and to consider what is expedient for the offender personally-according, e.g., as he is young or is hardenedas well as what is expedient in the interests of society as a whole. From time immemorial it has been recognised that Christian principle may be a safeguard towards realising the full responsibility of these duties, and a help to doing them in an entirely dispassionate manner. The institution of Assize sermons may have come to be little more than a formality, so far as any effect on the execution of justice is concerned, but it at least serves as a formal recognition of the difficulty of weighing the distinct and conflicting elements which constitute the expedient, and the need of guidance in doing it aright. Religious influence can and ought to come in, not to sway the judgment in any particular direction, but as an additional motive to secure that this duty of secular government shall be done in the best possible way. 
(b) Questions of expediency arise even in connection with the administration of justice; in regard to tho other functions of the State, they become still more prominent. The defence of the country against attack from without is one of the most elementary duties of any government, and in order to determine what it is wise to do for the sake of this object, a very careful forecast of the future is necessary. The probable action of other powers, and the possibilities of combination, have to be taken into account, as well as the progress in the art of war, and the weapons of attack which are likely to be available for the enemy. The coast defences, which might have sufficed a century ago when the sovereignty of the sea was undisputed-and martello towers were supposed to be gun-proof-are obviously worthless in the present day. Preparations in the way of fortifications, as well as in naval and military training and equipment, are very costly: all would agree that it is essential that such preparations should be adequate; but there may be the greatest possible difference in the forecasts as to what is necessary, and therefore as to what is right under the circumstances. It is fundamentally a question of what it is expedient to do, and of what may be left undone without incurring the charge of criminal recklessness.

When, however, the claims of the expedient are being satisfied, there is need to discuss the right way of raising the means for this necessary expenditure, and to decide how the burden shall be borne by different sections of the community. At this point considerations of justice to individuals ought to come in ; we should aim at distributing the burden so that there shall be equality in the sacrifice demanded from each individual. ${ }^{1}$ At best, this can only

1 Adam Smith appears to hold that equality of taxation means taxation in accordance with the benefit received. 'This might be sound if the principle of the Utilitarian State were accepted, and each man was called to pay for value received; but taxation is not levied by bargaining for a quid pro quo; the citizen is not free to break off the bargain : he is compelled to make a sacrifice for the common good. 
be secured roughly, and on the average. Differences of temperaments are incalculable, and what would be an intolerable sacrifice to one individual is of no account to another; this is one reason why it is impossible to gauge the sacrifice involved on the part of those who are forced to give up some comfort they have hitherto enjoyed. But apart altogether from the confusing elements of personal predilection and taste, it is no easy matter to decide, for certain, which of the citizens shall be called upon to make a sacrifice in any particular case. Questions of the incidence of taxation are very complicated; those, on whom the burden falls in the first instance, are often able to recoup themselves to some extent at the expense of other citizens, and thus to avoid making any real sacrifice themselves. There is a temptation to assume that money which it is easy to collect can be easily spared ; this may be the highwayman's view, but it is a dangerous principle in matters of State. Administrative convenience is always likely to have great influence on the government in the selection of any particular form of taxation. Convenience of collection was the chief reason in former days for laying the main burden of taxation on the landed rather than the moneyed classes, though the former had much less opportunity than the latter to recoup themselves in any way. Even if all these questions of detail could be satisfactorily and precisely disposed of, we should still be confronted with the most difficult of all the problems of equality in taxation-How is it to be levied so as to be fair to posterity? There is no doubt that posterity secures an advantage from having the affairs of the community handed down in good condition; but it is very difficult to assess, in terms of money, the precise advantage transmitted, while it is possible for each generation to shift the burden of a very large portion of the outlay from its own shoulders to those of succeeding generations. This can be most obviously done by borrowing; national credit can be employed so 
as to obtain large sums of money for immediate use, while the obligation to meet the annual interest remains to be defrayed by coming generations as well as by the citizens who incurred the expense. Pitt was strongly of opinion that the advantages to posterity which might result from a war were so problematical, and so difficult to assess, that it was right for each generation to pay its own way, and that the expenses of a war should be met by taxation raised within the year. Under the glamour of the magical results which were attributed to the Sinking Fund, this prudent view was abandoned, with disastrous results; and the pressure of indebtedness, due to increased armaments, seriously hampers the progress of all the great European nations. It is also worth remembering that a badly devised Fiscal System may cause injury to posterity in another way. If the economic prosperity of the country is injuriously affected by the methods of taxation adopted, there will be less wealth available for posterity to draw upon for every purpose. It is unfair to posterity either to impose obligations upon it-about which it cannot be consulted-or to tap the sources of national wealth imprudently. Prodigality will exist in public as well as in private life, so long as people are content to enjoy the heritage which has been handed down from the past, and yet feel no duty to pass it on unimpaired, and no desire to benefit those who come after them. The man who triumphantly asks, What has posterity done for me ? cannot be trusted to decide wisely between the demands of his own generation, and the provision which should be made for the future of the country.

Under these circumstances it is clear that no cut-anddried maxim of what is equitable in regard to taxation can be laid down; the system which is fair in one community might be very oppressive in others. ${ }^{1}$ The best we can

1 In a country such as India, where there are large patriarchal households, an income tax would fall very heavily on some men, whose married sons were living under the parental roof and not in homes of their own. 
do is to try to avoid what is unfair, both in the incidence of taxation among different men in this gencration, and as between the present generation and posterity. There is a continual temptation to be over-sanguine and to run the risk of sacrificing the future, so that we should welcome any elevating influences which can be brought to bear, to induce men to make prudent forecasts.

(c) There are still greater difficulties in laying down principles as to the discharge of another recognised function of government, that of promoting the welfare of the community-the advance of the subjects in health, wealth, and godliness. The welfare of society is not a very precise conception, for it has many distinct aspects-material, intellectual, artistic, and moral-and these various elements cannot be easily co-ordinated, even for some one country. Our aim ought to be high: on the one hand, to make the most of the material resources of the land, and on the other, to make the most of the inhabitants and to improve them in health and character and skill. But if this aim is to have a direct practical bearing, it must not be too much in the air, or assume the existence of human beings of a very different type from those we know: what is fanciful may be very pretty, but it can give us no direct guidance from day to day in actual life. Still, the conception of welfare need not be merely vague, as we render it more definite on one side after another, if we take stock of the best that has been attained by any of the peoples-in material prosperity, or scientific and artistic achievements, or in moral character-and seek to make the best which each has attained in its own line, our own. Such a conception of welfare, compounded from the actual experience of other peoples, can be brought into direct practical bearing; it is not a mere dream, but something that other people have rendered actual, and that we can imitate if we will be at the trouble. By far the greatest part of the progress which Englishmen made from the cleventh to the eighteenth 
century was directly due to the conscious imitation of other peoples, in some art or practice in which our forefathers felt they were behind; and the consideration of the conditions of life which obtain in other countries will help us to form a practicable conception of improved welfare for ourselves. The various elements of welfare are so different, and the different peoples of the world are so differently fitted to appreciate and enfoy them, that any attempt to devise a working conception for mankind as a whole would be a failure; it would contain too many incompatible elements. Still, we can form a definite view as to the manner in which the power of the State can be brought to bear on the people of any one country so as to improve the type of character or to increase the national prosperity. The current conception of national welfare will not, however, be elevating or inspiring unless it is rooted in a belief in Right and Righteousness as supreme over all the affairs of men. ${ }^{1}$ This is the element which has made the patriotism of the Israelite of old a model for the patriotism of all nations for all times. Christianity has set before us a far higher ideal of personal duty, but has not given us a better conception of a well-ordered earthly society, regulating mundane concerns and influencing all mankind. ${ }^{2}$ The Prophets believed in God as righteous; and looked eagerly for the purifying of their own nation, and its advance in prosperity and power, as the means of fulfilling a divine destiny in the world. The Psalms are the songs of a people who were conscious of a divine mission to mankind, and who felt, just for this very reason, that it was a duty to hold their own. 'Every nation,' as Maurice writes, 'should be an armed nation, not because it regards any other with hostility, not because it imagines that any other has an interest in assaulting it, but because its own soil, its own language, its own laws, its own government are given to it, and are beyond all measure precious to it. Any contempt of

1 See above, pp. 43, 46.

2 See below, p. 200. 
foreigners, any notion that we are better than they, is so much deduction from our strength, so much waste in braggadocio of the valour which is needed for the day of battle. Reverence for the rights and freedom of every nation is what we should earnestly cherish if we would be true defenders of our own. On the other hand, I cannot set much store by a man's interest in the well-being of strangers who is indifferent about the land of his fathers.' 1 The love of one's own people is not lost in a love of humanity. The area which is under one political and administrative system, and where similar conditions with regard to the employment of labour and capital, and similar obligations upon the taxpayers obtain throughout, is to be regarded as one country with aims of its own. In each country, as thus defined, the government exercises a supreme authority in shaping economic life. For good or for evil, the conventions and institutions of society have an extraordinary influence upon the material prosperity of the country and the well-being of the inhabitants; and it is therefore of supreme importance that this enormous power should be deliberately and systematically brought to bear, and that the economic policy should be carefully thought out and sound.

The matter becomes more precise when we take account of a somewhat fine distinction : the welfare of the country should be considered as the affair of an organised community, not as if it merely concerned an aggregate of individuals. In the body politic there is differentiation of function; in the body economic there is a division of labour; the advantage of the whole is attained by the co-operation of all the parts; but they are each highly specialised and by no means interchangeable. In so far as the country advances in welfare, all the individuals may share in the improved conditions, but it is an error to aim at the welfare of the individual, primarily and directly, as if he lived apart

1 Social Morality, p. 222. 
from society. The well-being of the individual follows as a consequence of social welfare; but it cannot be wisely sought apart from social welfare. When we are endeavouring to realise the welfare of the country, we are forced to recognise that the maxim of strict justice to individuals is not relevant. It cannot be insisted upon as an absolute guide, or taken as giving the last word; it is even more difficult to apply in connection with this function of government, than in regard to the infliction of punishment or the levying of taxation. In the changes which occur in the progress of society, it is impossible to be always introducing such readjustments that each individual shall be regularly treated exactly like every one else. We cannot hope to give effect to positive justice, but at best only to avoid serious injustice, and to do nothing which shall prevent any individual from realising his legitimate expectations of what he is entitled to in the existing order. Individuals perform different functions in society ; the parts they play are distinct, the services they render are not all equivalent; some are of greater importance and some less, and therefore it is not possible to abide by a fixed rule and to treat all individuals as if they were alike. The insistence on equality between individuals may even become positively injurious if it leads to efforts to keep all individuals alike ; measures imposed with a view to the maintenance of equality may prove to be inconsistent with the liberty of each citizen to take advantage of the opportunities within his reach for the development of his powers. The attempt to enforce equality of treatment among individuals must tend towards the maintenance of a dead level, and of stereotyped mediocrity. Freedom for differentiation and for the development of individual powers is essential to the welfare of the community; but such freedom gives scope for inequalities to arise and to be perpetuated.

(d) The welfare of society, and the means of realising it, are matters about which Christianity has no specific teaching 
to give. Its appeal is addressed primarily and directly to individuals, and it holds out the hope of an undying life. The welfare of society, in material prosperity or in human culture, is secular and mundane; and there is no special Christian doctrine as to the best means towards this end. This is the business of the State, and not specially that of the Church : the duty of the Church is merely indirect, and consists in using her influence, as far as possible, to secure that the duties of the State shall be done effectively, and as in the sight of God, by the persons who are responsible for discharging them. Christian influence should be brought to bear in order to reinforce the dictates of worldly wisdom by means of a higher motive. It is a Christian duty to make the most of all the things which God has created and entrusted to human care. It is a Christian duty to do our best for the service of man, and especially for elevating his character and improving his powers. The opinions of Christians, as to what is beneficial and what is injurious to the welfare of society, do not necessarily differ from the opinions of prudent men of any creed or of none : there is no specially Christian programme in regard to social or economic life. Our religion supplies the highest motive for endeavouring to realise the welfare of the country, by the means which ordinary prudence suggests, but it does not prescribe means of its own. The doctrine of Christ is universal and for all time, while the realisation of human welfare is contingent on varying conditions and circumstances. Just because these efforts depend on calculations of what is wise and forecasts of what is probable, there may be the greatest variety of opinion as to the wisdom of any particular course and the results that are to be looked for either immediately or ultimately. Christianity gives a new motive for the sacrifices which are necessary-especially the sacrifice of the present to the future-if the welfare of the country is to be steadily pursued.

The consideration of the true relation of Christianity to 
affairs of State may also help us to see that Christian influence can be brought to bear so as to diminish the friction and irritation of political life, and to enable the machinery of State to run more smoothly. Public business may be carried on in a Christian or in an unchristian spirit, and the unchristian atmosphere is unwholesome. There is often a temptation to condemn those who differ from us on political affairs, as morally wrong; it is particularly tempting for an earnest man who is eagerly advocating some particular reform, to allow himself to suppose that those who oppose him are indifferent to the end he has in view, and not merely doubtful as to the wisdom of the means he recommends. There are many men who regard it as axiomatic that the reduction in the number of public-houses would diminish the temptations to intemperance; they find it difficult to have patience with the protest that intemperance is more closely connected with the character than with the number of the houses. But it is at least conceivable that in a village where two or three publichouses are suppressed, and the one which is left is thereby enabled to provide greatly increased attractions, the temptations to intemperance may be positively increased. The protest against the hasty reduction of numbers may be honestly made by a man who is genuinely desirous that the cause of temperance should be advanced. The advocates of a measure are always in danger of attaching an exaggerated importance to one particular change: none of us has a right to assume that the means which he thinks the best for attaining a given object, is even a certain way of securing it, not to speak of being the only means. It is a Christian duty to doubt our own infallibility, and it is certainly uncharitable to take for granted that men who differ from us about the legislative means are therefore quite careless about the importance of the object aimed at. Still more unchristian is the assumption, in cases where public and private interests are closely intertwined, 
that a man's view on public matters is necessarily determined by considerations of private gain. It is easy to bandy accusations of self-seeking, and to assert that any one who does not take our view of what is beneficial or what is injurious is wholly indifferent to the welfare of society. But forecasts of the future, and of the probable effect of any proposed legislation, are primarily intellectual ; because another man's estimate differs from ours, we have no right to assume that his mind is distorted by moral obliquity; it may be so; but, on the other hand, he may have reached his conclusion dispassionatcly and without any selfish bias. When we read the story of the introduction of measures-such as the granting of allowances at the close of last century to supplement wages-which seem to have been very mischievous, we may yet find it impossible to blame those who devised them for carelessness or guilt of any kind. Christian charity demands that those we criticise should have the benefit of any doubt, and that, in all controversy, full allowance should be made for the possibility of wide differences of opinion on intellectual grounds; on all such points it is possible that further examination of the facts and of the probabilities may help men to be of one mind. The partisan is ready to assert that every one on the other side is indifferent to the welfare of the country, and is only actuated by selfish motives; but this crude judgment may have its foundation in unconscious self-revelation, since it is natural to attribute to others motives and conduct that are habitual to ourselves. At all events, it is not only a Christian duty to endeavour to pursue the welfare of the country earnestly and dispassionately, but to try to believe that others, who differ from us in opinion, are honestly working, according to their lights, for the same end.

As we enter on the discussion of the action of the government in regard to social questions, we may desist from any attempt to specify a definite Christian influence which 
ought to be exercised in one direction or another. It is a Christian duty to encourage and strengthen the hands of those who are working for the secular welfare of the community. By looking carefully at the manner in which governmental action may be best exercised, we can see more clearly how many things must be left undone unless they are taken up as personal duties; and it is in regard to these that specifically Christian principles can be effectively brought to bear.

\section{Favourable Conditions for Economic Life}

(a) In order to form any sound judgment as to the particular acts and conduct which are beneficial or injurious to the country, it is necessary to look a little more closely at welfare, and the means by which it may be attained. At first sight, the whole matter seems simple enough; there are certain elements which we can enumerate as essential to our idea of a well-ordered community. In contrast to existing conditions in Great Britain, we may insist that there ought to be a high standard of comfort and of culture for all the inhabitants, and that mutual helpfulness instead of rivalry should characterise their conduct. We may aim at introducing this condition, either by a sudden revolution or by a succession of gradual changes; but the vision of a community in which these conditions shall be rendered actual shines before some of us as a social ideal. To such men, the only problem worth discussion seems to be-How is this state of society to be introduced? But there is another question which it is necessary to face-When once introduced, how is this state of society to be maintained? It is by no means plain that this matter may be left to take care of itself. Any community is a living organism with change going on in all its parts, and with change in its relations to other communities; we cannot assume that any given scheme 
for society will always continue to fit these changing conditions.

Internal difficulties might easily arise which would disturb the existing order and tend to lower the standard of comfort. The tendency of population to increase is only kept at bay with difficulty, and in considering the various schemes of social reconstruction put forward from time to time, it is not clear by what means the standard of selfrestraint could be raised so as to prevent difficulties from the increase of population, or in what directions progress would be made so as to absorb the population as it increased. ${ }^{1}$

It is even more difficult to forecast the relations in which such a carefully ordered society might stand to the rest of the world. If it were possible to secure complete isolation, there might be no impulse from without that would bring about changes within; but in the world as we know it, no community can live a prosperous life in isolation from the rest of the world. It is at least possible that there might be occasion to organise attack or defence in the time to come, and that, as the outcome of hostilities, the community might have the opportunity of extending, or might on the other hand become subfect to another state. That developing commercial intercourse might have great effect in modifying the internal life of the community is also clear. $^{2}$ We could only allow ourselves to disregard the anxiety that influences from without might be the occasion of internal changes, on the supposition that every country in the world had developed up to the same level, so that the whole globe had entered on a stationary state economically, ${ }^{3}$ and also that a condition of universal peace was so firmly secured that no restless spirits or ambitious adventurer could upset it.

Since it is difficult to contemplate the future of society as stable, and impossible to guarantee conditions under which

1 See above, p. 3.

2 See above, p. 38.

¿. S. Mill, Political Economy (Ashley's edition), Book IV. vi. p. 746. 
some particular scheme of social reorganisation could be permanently realised, we are forced to regard nations as organisms growing in an ever-changing environment, and to concentrate attention on the conditions which render a healthy economic life possible in the present. From this point of view welfare is not to be thought of as if it were the same as wealth-a quantity of comforts and conveniences, or a mass of utilities which society possesses-but as a quality which characterises an organism that is healthy in all its parts.

Life is more than meat; welfare includes the power of enjoying as well as the means of enjoyment; we must not confine our attention to dead matter, and things external to man. More than physical bulwarks are needed for national defence: the wall which Hadrian erected to prevent the incursions of the Picts and Scots was not a mere physical barrier; its remains show that it is the skeleton of what was once a living system of defence; and an examination of the camps, the forts, and the frequent watch-towers helps us to understand how it was manned. In the same way, all the equipment and preparation which is required for carrying on any of the functions of State effectively and well, is to be thought of, not as a mass of goods, but in its relation to the life of a nation or a country. But for all that, earthworks and masonry are of primary importance in a system of defence, and external conditions of material prosperity are of supreme importance for the enjoyment of welfare. Without exaggerating the stress to be laid on material equipment, either for purposes of defence or as regards any other element in prosperity, we may certainly say that it is a sine qua non without which the community is unlikely to prosper in any direction : it is a matter of which the government ought to take great account. Intellectual and artistic achievement are impossible apart from leisure and freedom from sordid anxieties and activities, and material wealth is requisite if a community is to have the 
opportunity of enjoying the best of the heritage of human culture. It is therefore essential especially to consider the conditions which bring into play and promote the activities of economic life.

(b) Every community is made up of individuals, and its life is carried on by bringing the activities of individuals into play; each separate inhabitant may be regarded as one of the cells in the organised system of the life of the country. It is by their energy that work is done, and by their enterprise that provision is made for future requirements. The government can bring its influence to bear on these individuals in either of two ways-either by compulsion, or by the stimulus that is offered in the shape of reward. The system of compulsion has been habitual in tropical lands; it is suitable for a slave population; it is successful, by means of greater or less severity, in exacting regular and persistent labour; but even as regards labour it is much less effective than the hope of reward. So far as regards the other great factor in economic prosperityenterprise--the pressure of compulsion fails to elicit it altogether; the development of enterprise in a despotic state depends on the accident of some man of genius being at the head of affairs, either as the ruler or as a powerful minister. No community, which depends chiefly, if not exclusively, on the power of compulsion, is likely to attain to a healthy economic life, even though there are some outward tokens of great wealth and activity. On the other hand, the hope of reward appeals to free men ; it is natural to a state of society in which the inhabitants enjoy economic independence and political privileges. The gradual change, from conditions of compulsion to those of reward, has been characteristic of the progress of man in civilisation and in freedom. A return from conditions of reward to conditions of compulsion is only thinkable as a sign of decadence ; it would mean the diminution of frecdom of movement, and of freedom as to the use of time, and it must almost certainly 
involve a deterioration in personal energy. Under these circumstances, communities which are organised on the basis of compulsion, and the methods of exercising compulsion, may be left out of consideration here. It will suffice to consider what is beneficial to economic life, in those cases where the State depends on the energy and enterprise of individuals for securing the results it has in view, and when it endeavours to foster and stimulate them by the hope of reward.

(c) Two conditions, which governments ean maintain throughout a country, are of fundamental importance for fostering a vigorous economic life. On the one hand, there must be certainty of securing the hoped-for reward. If it is uncertain whether a man will reap the anticipated benefit or not, he is much less likely to engage in any sort of labour than he would otherwise be; but the importance of certainty of expectation is much more noticeable in regard to enterprise, since that involves the sacrifice of present possessions for the sake of advantages which can only accrue in a more or less distant future. There are, of course, many physical risks against which it is impossible for the government to guard in any way; but in all those matters which lie under its control, public authority will be wise to foster this certainty of expectation. Where there is a high degree of certainty, men may be willing to wait for a long-deferred reward; they may even engage in undertakings from which they will reap no personal reward, if they are able to count that advantage will accrue to their descendants. The planting of trees, and the sinking of capital in draining or other costly improvements, is habitually undertaken at great expense by private individuals with no hope of personal gain, but simply because of their confidence that their children or grandehildren will be better off. Such far-sighted use of material resources, by individuals at their own risk, would be seriously cheeked if there was reason to anticipate that the long-deferred 
advantage, when it arose, would not be reaped by those for whom it was intended.

The second condition is that the individual should be as free as possible to take advantage of any opportunities of using his powers, or the things he controls, in the way that seems to him most advantageous. If he has no choice as to the manner in which he exercises his powers, and uses his goods, he will make no effort to use them in a way that shall be more advantageous to society. If he is on the alert to note what the requirements of society are, and if he has the opportunity of turning his energies into those directions which meet these requirements, he will see his way to obtain a larger reward, because his action renders a greater service to the community by being turned into this new direction. It has been by an infinite number of experiments, undertaken by private individuals in the hope that a gain would accrue, that new routes of commerce have been opened up, new methods of agriculture adopted, and new processes of manufacture introduced. Thousands of these experiments have been utter failures. The resultant loss has fallen primarily on the individuals concerned, and the cost to society has been small ; but subsequent experiments have been more successful, and society has secured enormously increased power for controlling natural forces and for working up materials furnished by nature.

These two social conditions for vigorous economic life have been most effectively secured by governments which maintain a right of private property in land and in the other requisites of production. The right to possess implies a right to exclusive control, and therefore a right to use in the way that the possessor deems desirable. The prospect of transmitting improved fortunes to their children has proved the means of inducing men to enter on great undertakings, which could not result in anything but loss to themselves personally in the course of their own lives. The freedom of individuals to use their possessions as they 
chose has rendered it possible for the economic energies of the country to be turned into a vast number of directions, some of which might have been overlooked by the most far-seeing minister of economics. In a free country, organised on the basis of expectation of reward, the institution of private property seems to be essential to the vigour of economic life and the maintenance of prosperity.

\section{Grounds for State Interference}

(a) Individual property is not primitive, and in many parts of the world private property in land is unknown. The institution has no such sacredness as if it depended on some inherent natural right; ${ }^{1}$ its advantages and disadvantages, in all its forms, ought to be freely canvassed according to their bearing on the welfare of society. Private property has come to be recognised in the progress of society as the best means of calling out human activity, and as essential for the welfare of communities of free men ; but the precise manner and terms on which property is held in any community have been laid down by the law of that land. There is no principle of universal obligation throughout the world; the law of one country differs from that of another. The Land System and Land Laws of Scotland are very different both in principle and in details from those of England. The fabric of civil law exists to determine and define with precision what proprietary rights, in lands or goods, any individual is entitled to exercise with the authority of the State. But it is obvious that the State, which has given the title to enjoy private property, may be justified in modifying the exercise of these rights, or even in resuming them altogether. The State has granted a monopoly, and may be perfectly justified in buying the monopolist out and using the property in another fashion. On the right for the State to resume on proper

I See below, p. 194. 
terms what the State has granted, there need be no dispute ; but questions arise as to the occasions and conditions on which it is wise for the government to interfere. There is difficulty in seeing how far interference in any particular case will be beneficial to, and how far it will be infurious to, the welfare of the community. It is not likely that, in our complicated Inglish system, any governmental action will be either wholly and entirely good in its effects, or wholly and entirely bad; there must be immense difficulty in weighing the prospective good against the prospective evil in any particular case, and it is only possible here to indicate some of the considerations which may have to be taken into account.

(b) The right to use on the part of an individual is exclusive, not only against other private persons, but against the State also. If this right is exercised by a private person to the detriment of the community, it may certainly be resumed, after adequate compensation to the individual, so as to be put by the State to a better use, and one that subserves the welfare of the community better. The government is obviously justified in compulsorily buying out the landowner of an estate which is yielding ordinary crops, if it lies in a position where it is desirable to erect fortifications for national defence. This principle may also be acted upon, not only for political objects, but on strictly economic grounds, and for the prevention of the relative waste of national resources. If land is used as a deer forest, it may yield a large rental to the proprietor ; but the government may be clear that the interests of the public would be better served if it were planted with forest trees, and may be wise to buy out the landowner with this purpose in view. The only justification that is really needed for such action is the strong assurance, amounting to practical certainty, that the land will be better used by the government than by the individual proprietor, and that the welfare of the community will be really promoted by 
the change. When a great political object is in vicw, the decision may be comparatively easy ; the particular piece of property is specially wanted and must be secured if possible, and at any cost; but there is much greater difficulty when the problem is one of preventing the relative waste of national resources, by turning them to a better use. The question has arisen in a very practical form in connection with the agitation for small holdings, and, while it is doubtful how far small holders can compete with large capitalists, they have their best chance in those branches of farming which are most remunerative at present. The difficulty of managing small holdings was recognised as very great when the subject was examined by a parliamentary committee in 1843 ; and it is specially necessary to guard against the possible exhaustion of the soil by careless tenants. It appears to be generally assumed that when undertaken by public bodies this system must be so managed as to be remunerative to the State, and that the tenants of small holdings need not be subsidised at public expense. There is much to be said for trying to render them independent of any proprietor, but it is not clear that they will do better under the State than under private management. Desirable as the change might be, the upsetting of the existing use of the land, by tenant farmers and labourers, appears to many people to be unwise, until the probability that the welfare of the community will be increased by this new departure is more clearly established. The compulsory purchase of land under these circumstances is more difficult to justify than in cases where there is a practical certainty that advantage will accrue to the public.

What is, however, a matter of supreme importance for the welfare of the community, is that the State should not infringe its own guarantee, or fail to recognise the title of the proprietor for compensation. This is essential, not for the benefit of private persons, but for the credit of the 
State. In so far as there is the slightest breach of public faith with individuals, there is a risk that the confidence of all members of the community, in the certainty of enjoying the rewards of energy or enterprise, will be to some extent shaken; the economic vigour of the country will then be prejudicially affected in every direction. Any action on the part of the government that introduces fresh elements of uncertainty into the expectation of reward diminishes the stimulus to activity on the part of the people of the country. In retrospect it seems probable that the $£ 20,000,000$ which was distributed among slave owners in 1834, was an inadequate compensation, in view of the difficulty which was found in managing estates under the new system; and that the checkered story of the West Indian ${ }^{1}$ and South African colonies ${ }^{2}$ since that time has been partly due to the shock which was then given to the confidence of colonial investors in the wisdom and fairness of the British Government.

(c) Political considerations may be often adduced for interfering with the use of capital, and preventing proprietors from using their wealth in ways which would be lucrative. It may be right to forbid the carrying on of certain industries or branches of commerce. at all : the prohibitions of opium dens, and of the manufacture and sale of firearms and materials for war for possible enemies to use, are obviously justified by a consideration of the welfare of the community. It may also be desirable to prohibit the carrying on of a trade at such times and in such a fashion as to waste natural resources: there have been good grounds for regulating the Alaska seal trade, and, through lack of regulation, the timber of many districts has been recklessly destroyed. But the State may also be well advised to endeavour to guide the energies of the nation into some direction that is beneficial to the public, when it

' J. N. Dalton, The Cruise of H.M.S. 'Bacchante,' i. p. 117.

2 Egerton, British Colonial l'olicy, p. 277. 
is one that private enterprise cannot be trusted to take. Rewards may be offered in any of several ways-by the granting of concessions, or by subsidies of different kinds -in order to attract private capital into directions where it serves a public purpose. Such concessions have been granted to steamboat companies to establish routes for the more speedy conveyance of mails, or for the building of vessels which would be available for transport if it were requisite for military purposes.

(d) The economic life of a community is so important, that it is desirable that the government should have a policy, and co-ordinate the energies of the nation in such a way as to secure the best result. The free play of private capital brings about a development of different sides of economic life in a haphazard fashion; but if a careful forecast is made of the requirements of the country as a whole, it is possible to introduce a conscious co-operation that shall secure the result with less friction and waste. Serious risk arises in leaving such a matter as the food supply of the country entirely to chance, ${ }^{1}$ instead of endeavouring to minimise the causes that render it fluctuating or threaten to cut it off. In an industrial State, it is requisite that there should be a steady supply of materials, and this is a matter of public concern in regard to which private individuals cannot be trusted to take the necessary steps. It may be possible, by means of treaties with other powers, to enter into advantageous arrangements for these purposes from time to time. The most favourable conditions occur for bringing about permanent co-operation, and co-ordinating distinct activities, where a very large area, with dissimilar natural conditions, is under the same political control ; this provides the maximum of stability and diminishes risks and uncertainties. The genius of Alexander Hamilton ${ }^{2}$ prevailed to procure exceptional advantages for the United States, by insisting that the

1 See below, p. 167. 2 F. S. Oliver, Alexander Hamilton. 
entire territory should be treated as a single whole for commercial purposes, and consequently for economic development. Similar advantages have been found, since the barriers which separated the various German States into independent units have been broken down, and it has been possible to pursuc one policy, consciously and deliberately, for the whole Empire. If a similar clear and definite purpose were to make itself felt in regard to the separate countries which form the British Empire, it could not fail to bring the various elements into closer co-operation; it would thus tend, not only to the successful development of each part, but to the increased stability of the whole. The matter is so important that we should not continue to trust to chance, but ought to take the trouble to make the economic development of the Empire, in its separate parts and as a whole, a matter of serious thought. The commercial intercourse between this and other countries is not sure to work out in the best possible fashion if it is left entirely in private hands. No advantage can arise from a determination on the part of any government to shirk responsibilities which must be considered by public authorities, if they are to be made the subject of consideration at all.

The doctrine of allowing perfect free play to private interests, in the confidence that they will unconsciously work for the good of the country as a whole, is exceedingly plausible. But during the course of last century this principle of laisser faire was entirely discredited, so far as the internal condition of the country is concerned. The accounts of the condition of women and children in the factory districts and in mines forced the public to recognise that private interests provided no safeguard against the physical deterioration of the race, and that the limitation of hours of work, and the inspection of places where work was carried on, were necessary for the sake of the health of the coming generation. The insufficiency of the principle 
of leaving free play for private interests having been established in one case, it has been altogether discredited, and inroads have been made upon it from every side and on many different pretexts ; but this is a new source of danger; there was something to be said for the rule, and there ought to be careful consideration of each exception. The economic life of the country cannot be carried on steadily and healthily, when there is occasional interruption on behalf of some special philanthropic or political object. It is only by giving constant and systematic attention to the economic life of the country, and prescribing a regimen by which humanitarian and political interests can be constantly considered, that we escape the uncertainty which arises from spasmodic interference and sentimental or interested agitation. ${ }^{1}$

\section{The Criteria of Healthy Economic Life}

(a) The sufficiency or insufficiency of employment is the test which shows most clearly whether the economic life of a country is in a healthy condition or not. The rate of profits, the value of land, the statistics of trade, and all sorts of other criteria have been appealed to by different experts in discussing this subject, and each of these may be important with regard to some particular inquiry; but the condition of the population is the essential thing as regards the community as a whole. Infant mortality, according to Malthus, ${ }^{2}$ was the most instructive symptom to notice in order to decide whether the population was redundant; and the sufficiency of employment is the best test to apply in order to see whether the conditions in which people live are favourable to the development of character ${ }^{3}$ or not. The man who has work to do is able to lead a disciplined life ; he preserves his personal independence by earning his own living, and he has a prospect of improving in skill or

\footnotetext{
1 See above, p. 63.

2 See above, p. 3.

3 See above, p. 9.
} 
experience, and thus of becoming fit for more remunerative employment. The man who, for any cause, is unemployed is in danger of losing the habits of regular life, and of gradually forfeiting his self-respect; he passes by degrees from the ranks of the unemployed to swell the numbers of the mere loafers who are unemployable. In progressive communities there is constant change; and in the course of these changes temporary unemployment is sure to arise ; but in a State that is not only progressive but healthy, the labourers who are thrown out from one department can, sooner or later, be absorbed somewhere else. The really serious symptom appears when unemployment becomes chronic, and a section of the community, whether large or small, habitually live in enforced idleness, and are either driven into crime or are satisfied to be maintained as paupers.

The existence of a large population of pauperised citizens was one of the earliest and most noticeable features of the disease which affected the economic life of ancient Rome. The city of Rome was able to procure supplies of corn, partly as tribute from subject peoples among whom her administrative and military system extended, and partly as interest on the large amount of Roman capital which was invested in the provinces. There was no necessity to rely on the neighbouring territory for supplies of food, or to purchase them in exchange for the products of Roman industry. Agricultural life and manufacturing were alike depressed ; but supplies of food were forthcoming at Rome for a population that failed to find employment in any productive avocation. The strength of the Empire was such that this state of affairs continued for generations, and did not by any means prove fatal immediately; but other States may do well to take heed of the warning, and not to be misled by any outward indications of wealth and prosperity into neglecting the significance of this dangerous symptom. 
(b) Such political objects as the maintenance of a healthy condition at home and of a position of influence abroad are of supreme importance. They have to be dealt with on such a large scale, or involve such far-distant consequences, that they lie outside the scope of individual action and beyond the span of individual expectation. For this very reason they cannot be estimated and compared in the terms we use for ordinary transactions. We have means of assessing the benefit or injury that comes to individuals, but we have no standard in terms of which we can attempt to measure any benefit or mischief that accrues to the community as a whole, present and to come. For all ordinary purposes money serves, not only as a medium which facilitates exchange, but as a standard which measures value. The value thus measured is value to the individual, and not value to the community as a whole. Money measurement is not directly applicable to goods or services, when viewed from the point of view of what is beneficial or injurious to the State as a whole. It is not a test we can trust to, or regard as decisive, even though we may be wise not to discard it altogether.

Current money is a standard by which we can measure the values of the goods and services that circulate in any community. The standard is not, and cannot be, absolutely fixed and invariable; but the variations in the value of money are comparatively slow. Its value is more stable and less subject to fluctuation than that of other valuable things; it serves as a fairly constant standard for short periods, and as knowledge advances, we are obtaining more and more data with the help of which we can estimate and correct the variations in this standard. ${ }^{1}$ For practical purposes this standard serves sufficiently, and we can state the value of goods, or services, with a high degree of

1 For recent periods see W. S. Jevons, 'A serious fall in the value of Gold' in Investigations in Currency and Finance, p. 13 . In regard to the distant past, it is more convenient to take the common food of the people as the basis of comparison. 
accuracy, by quoting the price at which goods may be bought, or labour hired. But value is not a fixed quality inherent in, or intrinsic to, a commodity, as coal is black and lead heavy in all places and at all times. The value of any commodity is constantly varying, either according to the quantity available, or owing to causes which render the public more or less eager to procure it; its value is the relation of exchange in which any commodity stands at any given time and in any particular circumstances. The value of anything for purposes of exchange can only be determined for certain by actual bargaining; a thing is worth what it will fetch. Those things which cannot be exchanged, and are not marketable objects, have no exchange-value; they cannot be bargained for or purchased, and therefore they have no price. Such elements of human welfare as health, or experience, which are embodied in each individual personally, may, of course, affect the terms on which he is hired, but since he cannot divest himself of them and hand them over to any one else, they are not themselves the subject of exchange, and therefore it is impossible to quote the precise price at which they can be bought or sold. The ordinary methods of money measurement are not directly applicable to personal qualities of any kind ; and hence money measurements cannot be employed to reckon up the most important elements in national welfare.

Even in regard to material objects, estimates of their importance to the community in terms of price are likely to be very misleading. Market price arises from the bargaining of individual buyers and sellers with one another; the limits within which it ranges are determined, on one hand, by the utility of the article in question to the man who owns it, and by its utility to some possible purchaser on the other. The view of each individual is determined by his own circumstances, and his opportunities for using or disposing of the thing about which he is bargaining. A personal 
element lies in the background; and though the manner in which this affects particular bargains is so slight as to be inappreciable and entirely negligible, the cumulative effect is of considerable importance. The life of the State is so long that the estimate of utility to the community may differ considerably from that of utility to the individual owner. It may obviously be to the interest of the individual owner to realise his possessions rapidly, so as to have the means of enjoyment-accumulated wealth-in forms in which he can invest it so as to bring in an income. On the other hand, the interest of the State may demand that the mineral wealth of the country should not be rapidly exhausted. The same sort of thing occurs with regard to the surface of the land; a tenant may find it to his interest to grow crops which tend to exhaust the soil, while it is the interest of the community that the land should be kept regularly and permanently in good condition. It is possible to estimate the terms on which the goods of each individual would be exchanged if brought to market, and therefore to reckon up the aggregate of the wealth of individuals, but the sum total cannot be used as an accurate statement of the resources of the community. The right mode of reckoning the wealth owned by private citizens and lent to the State is another difficulty. It is wealth to the individuals and a burden to the State; while the fact that the State bears the burden is an instructive indication of its vitality. The worth in money of their possessions, to individuals, is a very defective account of national resources and their importance for the State. ${ }^{1}$ Personal qualities are not reckoned at all, and property is estimated from a different point of view. To use Adam Smith's phrase, the total of the exchange-value, from the point of view of individuals, is a very inadequate way of representing the value-in-use to the State.

1 On the importance of the distinction drawn by Adam Smith between profit to individuals and advantage to the nation, compare Nicholoon, $A$ I'roject of Empire, pp. $49,5: 3,60$. 
(c) It follows from this distinction that we cannot judge of what is beneficial or injurious to the community by simply considering how any given course will affect the aggregate of individual wealth. A restriction in the hours of labour is quite likely to diminish the aggregate of wealth produced; this loss may possibly be indirectly replaced through an increase of intensity of labour during the shorter day; and even if this beneficial result does not occur, and the loss is a permanent loss that diminishes the aggregate wealth of the country, it is not necessarily injurious. The increased leisure may be worth paying for, from the point of view of national welfare; and the cost involved may be something that the community can afford, without crippling its productive power. But it is foolhardy in the extreme to take for granted that this must be the case: the effect of any proposed change on the aggregate of individual wealth ought to be most carefully taken into consideration in connection with such a proposal as an eight hours day. By taking account of the probable effect it will have on the aggregate of wealth, we can estimate at what cost such a change can be made, and then we can begin to consider whether the prospective benefits are worth securing at this cost. There is an analogy in the case of the city clerk who is fond of gardening; instead of buying fruit and vegetables from the greengrocer, he arranges to take a piece of garden ground and works in it himself. He may find that he has an immense amount of pleasant recreation, the satisfaction of which cannot be estimated in terms of money. It may be, however, that the rent and the outlay of his garden come to a good deal of money, and that his fruit and vegetables prove to be much more costly-if more attractive-than those supplied by the greengrocer. If he is a sensible man, he will try to reckon up what the loss upon growing his own fruit or vegetables is. He will then be able to know what he pays for the recreation, and to decide whether he ought to refrain from other forms of 
expenditure-for example, on his wife's dress-and spend so much out of his limited income for this particular recreation. Very likely he may decide that he ought, but he should think the matter out and not make the decision in the dark. Questions of wise or unwise national economy are very similar to those of wise or unwise household economy ; we cannot have luxuries of any kind unless they are paid for, and we ought to know how much is paid and who pays it.

This last point needs very careful examination if we are to reach a sound conclusion. At first sight it appears that if the aggregate of wealth is diminished, that merely means that the wealthy pay-and that the poor enjoy more leisure-a rearrangement which makes for equality, even if it is not obviously fair. But it is a mistake to suppose that wealth remains fixed in any hands : it is continually being expended on one object or another, and is thus put into circulation: in one form or other it brings about the employment of labour. Some men use their money as capital and employ labour; others spend it as income, and replace the capital of those who manufacture the things they buy. In one way or another, it is used directly or indirectly for the employment of labour; some forms of expenditure occasion the employment of a larger and some of a smaller number of hands, according to the proportions in which capital enters into different forms of economic activity. But any decrease of the aggregate of wealth is almost certain to diminish the volume of wealth in circulation, and both to change the character and reduce the amount of the demand for employment. This is a national evil which it is desirable to avoid at any sacrifice.

There are other public purposes with reference to which it is most important to take account of the aggregate of individual wealth. In order that the government of the country may be carried on, there must be an available revenue, and this is obtained, in some form or other, from 
the pockets of the people. There are an infinite variety of objects-and desirable objects-on which the State may spend money, and there is a tendency for this expenditure to increase by leaps and bounds; but it can only be carried on by reducing the available wealth in the possession of private persons. Much of the expenditure of private persons is devoted to the production of forms of material wealth, which, in the process of being used, contribute to the production of new forms of material wealth in the future. The expenditure of the government does not, for the most part, take the form of providing means for the future production of material wealth, and may, on the whole, be classified as unproductive. In so far as an increase of unproductive expenditure by the State reduces the productive expenditure of private persons, it tends to decrease the prospective facilities for employment, and thus to bring about serious mischief. However desirable some form of public expenditure may be in itself, there is hardly any that is so essential to the welfare of the community as to make it wise to run a risk of diminishing the field of employment. 


\section{CHAPTER II}

\section{THE REWARD OF SERVICES}

1. The Framework of Society and the Force of Competition

(a) For the maintenance and progress of the economic life of any community three physical factors are requisitelabour, capital, and land. The precise status and method of managing each differ enormously at different times, and according to different conditions of race and environmentlabour may be supplied by slaves or by free men; capital may be a personal possession or the joint-stock of many men; land may be assigned to individuals, or retained under the direct management of the State. But in any case, labour, capital, and land are all necessary for the economic life of organised society. It is obvious that labour and land are requisite in all times and places, and though in primitive societies capital only exists in very rudimentary forms, it is also essential in any community which is organised on a large scale, and where the people are habituated to buying requisites and selling surplus commodities in the markets of the world. The interplay of these physical factors in material prosperity has most frequently given rise to the problems of social life. These problems are, however, more complex than if they were merely concerned with the accumulation and division of external goods. They have a human side as well-and this is by far the more important aspect, as it is the end which must be kept in sight. The mutual relations of human beings to one another are being constantly readjusted, 
and there are, under diverse conditions, different opportunities for a man to develop his personality and to improve in intelligence and character. The social problem is always with us; it presents itself in a new form in every age and country; it has always a double aspect, since it involves both the increase of material prosperity and the improvement of personal character. The latter is by far the more important, as it is the end in view; but the former demands careful consideration, as it supplies the means for attaining this end.

(b) The precise nature of the service which each of these factors renders to society ${ }^{1}$ is set in a clear light, if we contrast the economic life of a primitive with that of a highly organised society. Such a contrast is easily drawn, in a case where there is no difference of race to be taken into account. We have, for instance, very full data which enable us to compare the condition of Cambridgeshire villages in the time of Edward I. and at the present day. In many of them the population was as large, six centuries ago, as it is to-day, but there were great differences in their habits of life. At the earlier date each family carried on agriculture mainly for the supply of its own needs and not for sending to market, and the agriculture was organised partly on individualist and partly on what may be called collectivist lines. The necessary clothes and implements were, to a large extent, of home manufacture, and buying and selling only occurred occasionally, in order to dispose of a special surplus or to meet some exceptional requirement. At the present time the population are almost entirely employed in raising produce to be sold. It has become habitual to frequent the Cambridge market and to purchase goods at shops. It is almost impossible to gauge the precise change which has taken place in the standard of comfort between these dates, but it is possible to form a

1 This morle of treatment is more accurate than that which represents Capital as rendering service to Labour. 
rough guess in regard to certain important elements. The house accommodation in the thirteenth century was very much worse than that at the beginning of the nineteenth, defective as we now regard the provision which was made for the housing of the rural population a century ago. The occasional inventories which have come down make it clear that, so far as furniture and household utensils are concerned, the cottager of the thirteenth century was infinitely worse off; he may have had some advantage in the quantities of bread and beer which were available for his consumption, and we have no means of comparing the quality of these necessaries ; but the villager in the present day has access to a much greater variety of supplies both for clothing and for food-including tea, tobacco, sugar, and fruit - than was possible in bygone times. To institute any comparison in personal qualities is more difficult; but at all events the villager of the present day has a much fuller life, since he has greater opportunity for freedom of movement, and for acquiring information about the events of the great world than was possible when railways and printed newspapers were unknown. There are no data for a comparison of the standard of moral character, but the records of crimes adjudicated upon in the King's courts, and of punishments inflicted in the Manorial courts, leave the impression that in this respect there has been no deterioration. Moreover, from what we know of the death rate, it is impossible to believe that the population really enjoyed a high standard of bodily comfort. The villager of the present day appears to be as well off in almost every respect, and much better off in some of the principal conditions of bodily comfort; while, in the opportunities for having a share in the thought and interest of the world at large, the man of the present day is infinitely better off; but the difference becomes more striking when we look at England as a whole. In the thirteenth century the nation consisted of thousands of separate villages of a similar type; town 
life was in its infancy, and the trade of the country was chiefly carried on by foreign merchants in foreign ships. Though some of the Cambridgeshire villages have slightly declined in population during these seven centuries, England as a whole has increased enormously in numbers, and therefore in the power of bringing organised labour to bear on the production of goods. So far as facilities for defence are concerned, the Navy, which sailed under Nelson's flag to Trafalgar, was far better equipped than that which Edward IIr. commanded when he won the battle of Sluys. The enormous increase in the wealth and power of the country gives the best indication of the nature of the services which have been rendered to the community by the intelligent administration of land and of capital.

Land may be used for many different purposes; in the thirteenth century much of it was waste, and what was employed in tillage was entirely unimproved. In the progress that has taken place since that time, landowners have had an important part to play; they and their agents have endeavoured to regulate the use of land, so that it shall not be exhausted in the process of cultivation; and since the beginning of the eighteenth century they have, as a body, devoted themselves to the permanent improvement of the land for agricultural purposes. Suitable buildings have been erected, roads have been laid down to convey the produce to market, and fields have been fenced and drained, so that the productiveness of the country has been enormously increased. 1 Wherethe land is used more intensively, there has been a still greater expenditure in fitting it to serve another social purpose. The laying out of an estate for building purposes, with the necessary roads and sewering, is a very costly affair ; and many landlords may have difficulty in finding the means for undertaking work of the sort; but it has been done on a large scale, and provision has been made for the housing of an enormously 
increased community. The work that has been done in developing the mineral resources of the country, and rendering them available to meet the requirements of the community, is another important service which has been rendered by landowners. In retrospect we may say, that the function of the landowner in the economy of the State has been that of making permanent improvements in the land of the country and adapting it to the new uses which came to be required through the progress of society.

The owners of capital have also contributed their share to the progress of society. It is through their intervention that goods can be brought to market, and distributed to the parts of the country where they are most required. In Elizabethan times it was extraordinarily difficult to render the corn grown in the country available, so that the requirements of every part of the country should be met in the best way. Much pains was taken to effect this result; and the development of the internal corn trade has at last solved the problem, and private individuals can be trusted to perform this service without being subjected to constant supervision. The marketing of the manufactures of the country, and the arrangements for exporting them, have also been organised by the owners of capital, and they have provided the mercantile marine which has grown to such enormous dimensions, and on which the very existence of the community is now dependent.

The owners of capital have also rendered a service to society by providing equipment to enable the labourer to do his work faster and better. This side of capitalist activity has been especially conspicuous during the last century and a half ; the inventions of James Watt, of Arkwright, and of Stephenson have been introduced so as to revolutionise industrial processes of every kind, and to render it possible to obtain an infinitely increased result with a very small amount of drudgery. In general terms, the task of the capitalist has been that of organising and directing and 
supervising the labour of the country, so that it shall meet the needs of the community to the fullest possible extent.

These services have been rendered by private individuals in the past ; it is quite arguable that they might have been equally well supplied by the agents and factors of the State, and that if they had been performed in this way, they would have been carried out at less expense. To that question we may return, ${ }^{1}$ but at the moment it is important to note what the services rendered to the community by the owner of capital and the owner of land have been; they are necessary services which are essential to the existence of organised society, and whatever reconstruction of society may go on, the present degree of prosperity cannot be maintained if these functions are not as well discharged in the future as they have been in the past.

(c) Another great contrast between the village life in the present day and in the thirteenth century lies in the fact that the economic relations of the inhabitants are no longer regulated by custom but are settled by competition. The thirteenth-century labourer paid customary services to his lord, which may be regarded as corresponding to a rent for the use of the land he occupied and from which he procured the means of subsistence. In so far as definite services were commuted for payments in money, they also had a customary character. The great defect of this system lay in the fact that there was so little room for distinguishing between good work and bad, and that the amount could not be adjusted with any precision to the work done by the labourer. In those cases where customary prices are still maintained this defect is noticeable; the cabman who drives one mile and 1750 yards in London is underpaid with a shilling, if the man who drives 11 yards farther has really earned eighteenpence. The introduction of money payments, and of competition, has

1 See below, pp. $150 \mathrm{f}$. 
made it possible to adjust wages with much greater precision than before, and to secure that the man shall be paid more exactly in accordance with the worth of the work done. There are, however, defects in the method of settling wages by competition which must not be overlooked. In many cases of bargaining, one side is likely to be in a stronger position than the other, through being less anxious to conclude the bargain in a hurry. ${ }^{1}$ On the whole, the employing class have been in this position with regard to labour; but there have been exceptional cases where the labourer has been in much the stronger position. A striking case in point was furnished at the time of the Black Death, when, owing to the effects of the pestilence, labourers were unusually scarce, and were able to take advantage of their position to demand what were regarded as exorbitant rates, under the threat of refusing to carry on the cultivation of the country and other necessary avocations at all. On more than one occasion it has been deemed necessary for the State to step in and use its influence on behalf of the side which was economically weak. The Statute of Labourers was one example of such intervention, and the whole history of nineteenth-century legislation in regard to the work of women and children in factories is an example of intervention on behalf of the employed.

Another evil arises in connection with competition; there is a danger that advantage will be taken of the opportunities which the modern organisation of society offers, for adulteration, and for supplying goods of an inferior quality. Frequently the purchaser, who buys

1 It is commonly said that in every exchange each party to the exchange gains, and this is true; no one need conclude a bargain unless he thinks that it is to his advantage to do so, and that the thing which he obtains in exchange is more useful to him than the thing he gives in exchange; but the man who is least anxious to get what the other has to offer, can drive the harder bargain, and force the more eager bargainer to take what is of very little more use to him than the thing he has to give. Generally speaking, the more wealthy man is better able to wait, and has inore opportunity of looking elsewhere for what he wants, than the poor man ; and therefore the wealthy man may often be in the position of being able to drive a haril bargain with the poor man. 
things he wants to use, is not a very good judge of the quality of the article he is buying; he is apt to look chiefly at the price, and to give a decided preference to what is low-priced, in the hope that it may turn out on trial to be good in quality and therefore cheap. When the craftsman and the purchaser were neighbours, the purchaser had no doubt where the responsibility lay if the goods turned out to be bad, and this afforded a certain safeguard; if the wares proved to be 'slightly wrought,' or not 'substantial,' he could make a definite complaint, and possibly obtain redress through the craft-guild organisation. But this local safeguard is removed when the merchant intervenes; when goods are sold in distant markets, the customer has no real means of making an effective complaint against the manufacturer. The merchant may be an expert buyer, but if he finds that there is a ready sale for inferior goods of cheap quality, he may think he can do the best business and undersell rival traders by continuing to supply them. In the Middle Ages, the more favourable conditions of direct dealing did not suffice to maintain the quality of goods ; an elaborate system of mutual supervision was organised in every town by means of craft-guilds, which were empowered to act in the interest of the public under municipal authority. Careful arrangements were also made with regard to the export trade, with the view of building up a high reputation for English goods in foreign markets. In modern times it has been still more necessary to take precautions against adulteration, and for giving security to the buyer as to the quality of goods ; but there is always a danger that this evil may break out when competition is entirely unregulated. In some cases it may prove so injurious as to bring about the entire destruction of a branch of trade.

(d) The evils of the driving of hard bargains and of the sale of inferior goods are so serious, that there can be no doubt as to the necessity for regulating competition so as to 
protect the weak, and to maintain a high quality of production. A great deal has been done in this direction; as this has been introduced as the results of experience, it has on the whole been wisely done. Unwise regulation hampers industry and commerce unnecessarily; but so long as regulation is wise, and puts down admitted evils at small expense, it should be welcomed. The extreme advocates of laisser faire, who hold that individuals should be taught to look out for themselves in all the incidents of economic life, seem to be almost extinct; but there are many people who regard regulation as an inadequate remedy. They hold that the evils are so deeply rooted in the system of competition, that we can only hope to get rid of them by abolishing competition altogether, and establishing some system of regulation by which the need for bargaining will be done away.

There is some reason to doubt, however, whether this would be practicable at all. The doing away with competition altogether, implies the abolition of bargaining both for goods and services. In a society where there is no bargaining there can be no price, and no method of determining the exchange-value of any commodity. If this method of determining values is abandoned, it is hard to see by what method the relative value of different services to the community could be assessed. Even if this difficulty were overcome, and there were no change in the processes of production, or in the trading relations with other countries, the original assessment of values might continue to be satisfactory : but if there were changes of any sort, some readjustment would be desirable, and there would be great difficulty in carrying out readjustments which would be regarded as acceptable by all the parties concerned. It is very difficult to conceive a social system in which bargaining should be altogether abolished while there was yet freedom for change. The complete elimination of competition, and the carrying on all business affairs as a 
complex system of State monopoly, would be beset with extraordinary difficulties. Many of the advantages which would accrue from the reduction of the evils of competition are being secured through the efforts, constantly made by private persons, to reduce the waste arising from competition, and to introduce more complete and more extensive organisation. This change is continually going on ; many savings may be effected when a business is conducted on a large scale ; and there is, in consequence, a steady tendency for firms, both commercial and industrial, to combine so as to eliminate the loss and waste which may arise in the course of competition. It is commonly said that competition inevitably leads to monopoly. ${ }^{1}$ This word has ugly associations, but it does not necessarily follow that the monopolist will use his exclusive powers to extort money from the public, by serving them badly. In nine times out of ten he will obtain the largest return by setting himself to serve them as well as he can; there is no certainty that the State might not work its monopoly with the view of obtaining as much gain as possible, and not with the view of serving the public well. If a private monopolist neglects the welfare of the public altogether, citizens may be able to attain some redress by appealing to the law of the land, or to administrative authorities ; there is, besides, always a chance that a practical monopoly in private hands may be broken down by some energetic rival. On the other hand, when business is once organised as a department of municipal or public life, it is impossible for private persons to compete; and the authorities may find it difficult to relinquish the undertaking. Government departments are to a considerable extent irresponsible ; it is very difficult to convict them of a mistake, or to get redress for any carelessness. A monopoly in private hands can be regulated in many ways by such an authority as the Board of Trade ; it can be sued in the ordinary courts, and it can

1 See below, p. 134. 
at least be effectively criticised. The State management of railways may be the best system in some countries, but there is no reason to suppose that it would be preferable to that of a company under all circumstances. It would be a doubtful experiment to introduce this system for many kinds of business, and to extinguish private trading altogether, before the complete superiority of State management is proved.

\section{The Reward of Labour}

(a) There is a great contrast between the thirteenthcentury and twentieth-century England in regard to the grouping of the people into an organised society. Seven centuries ago there were marked divisions of status between different landowners, according to the tenure by which they held, and according to their condition as freemen or as villeins; and the inhabitants of each town were divided up according to their occupations. The lines of cleavage between these various groups were so deeply marked that the mere accumulation of wealth did not serve to obliterate them; one villein might have become a rich man, and another rendered poor, but they occupied the same social status, with its rights and its disabilities. Though there was no such hard and fast caste system as there is in India in the present day, changes of status were made with difficulty, and occupations tended to be hereditary. Economic progress has done much to reduce the importance of these barriers, and a new method of division, into classes, has come into being. There are broad lines of division between the professional classes, who undergo a long and expensive education, the skilled artisan, who has also required some years of training, and the labourer who may be active and hardworking, but has no specialised skill of any kind. These class divisions are marked by economic differences; the class that can afford to undergo a long 
training for the business of life is not affected by the competition of those who have not had such training : each class has its own standard of life; the members of each class endeavour to secure such a rate of reward as will enable them to maintain that standard, and this determines the great differences in the ordinary rate of reward, as between the professional and the working classes. The man who enters on a profession expects to be able to earn three or four hundred a year, while the artisan can look forward to about a quarter of that rate. The professions may be overcrowded; this does not mean, however, that the rate of reward is brought down, but that many individuals have to drop out of the competition, and try to obtain a living outside the ranks of their own calling. The standard of comfort among the skilled artisans is maintained in a somewhat similar fashion; while the ranks of the lowest class are swelled by the broken men who have, from various reasons, proved failures in their own class.

In commercial circles there are enormous differences in the remuneration earned; the men who do routine work are very poorly paid, while those who hold positions of trust and responsibility are paid at very high rates. In this case, however, there may be very little difference in the amount of training required; or at best, training may serve to give a man a better start, but it does not do much to enable him to keep up in the race. The various personal qualities which go to make up business capacity-such as sound and rapid judgment and persistence-all tell ; and the man who, even in a small sphere, shows such qualities may rise to very high positions indeed. A man may best prove his fitness for such positions by the experience he has acquired and the capacity he has shown in actual.life, and not by the completeness of his preliminary training. Hence, in regard to business positions, there is much more competition of individual with individual, and much more prospect of rising from a position which is comparable to 
that of an artisan, to one which commands a much higher income than any but the exceptional professional men can hope to secure.

The main point can perhaps be brought out by the use of a metaphor, which affords a convenient means of illustration. We may think of a man's skill and experience as a kind of 'personal capital' fixed in his own individual life. The broad differences in the rate of the reward which he can earn, by turning his faculties into play in one calling or another, are due to the differences of personal capitalwhether acquired by training or experience-which he has at his disposal ; effective competition for opportunities of employment, and for greater or less reward, is carried on between individuals who are equipped with similar personal capital. In avocations, which involve similar amounts of personal capital, the rate of pay will differ according to the probabilities of regular employment, or to the agreeable nature of the employment; callings, which are attractive on these grounds, are likely to be remunerated at a lower rate, while a high rate of reward may be needed to induce men to engage in work which is irregular or dangerous. The competition of individual with individual is probably a satisfactory method of settling these differences in a manner which is at once precise and fair. The assignment of callings to individuals would be a very difficult duty in an organised society, where there were neither hereditary preferences nor opportunities for the exercise of personal choice. The extreme differences, between the man who draws a large salary with very little drudgery and the man who works hard for long hours for a bare living, are due to the different amounts of personal capital available in each case, and are closely connected with the relative importance, for the life of the community, of various forms of personal capital.

(b) Class distinctions are not arbitrary. In a society where the economic life is determined by the hope of reward, 
they open out a range of ambitions which afford a stimulus that would not otherwise exist for a man to work energetically in his calling. In order that this stimulus may operate effectively, it is desirable that there should be facilities for rising in the world and for passing from one class to another. In the Middle Ages, there was an opportunity for ecclesiastics to rise to the highest political positions, either in what we should call the Civil or the Diplomatic Service; but in other respects there was little opportunity of change, and few opportunities of rising in the world. In modern times, the best men have opportunities of coming to the front in business, though, owing to the immense scale on which business is now organised, it is probable that many men of real ability never have any opportunity of showing what they have in them, or of having their capacity recognised and appreciated. The educational ladder is so far complete as to give clever boys, from any class, the means of entering the ranks of the professions, if they are not only clever, but persevering, and have some faculty of adapting themselves to new social conditions. On the other hand, the changes which took place in England during the nineteenth century broke away the steps by which agricultural labourers had been able to rise in the world. So long as corn-growing was the most remunerative branch of farming, the system of small holdings was unable to hold its own economically in competition with farming on a large scale, and it died out. Even if it was inconsistent with the introduction of the best methods of cultivation, it had an encouraging influence on the best elements in rural life, as the energetic labourer had within his reach the opportunity of being able to work on his own account; and, if he was successful on a small scale, to obtain a larger holding and become a substantial man. The consolidation of small farms, which went on pari passu with the progress of enclosure in the eighteenth and nineteenth centuries, has cut away the steps in the ladder. For most agricultural labourers 
there is no opportunity of rising in the world, by practising the calling in which they have been trained. The provision of increased numbers of small holders may not result in the creation of a large and prosperous class of cultivating peasantry; but it is at all events likely to afford an opportunity for the men of exceptional ability and energy to rise in the world, and thus to open up an attraction to induce energetic men who prefer life in the country to settle on the land.

When social distinctions are insurmountable, they are likely to give rise to increasing bitterness and irritation, especially if there is no obvious reason on which the difference of condition rests. But class distinctions, which rest on differences in the possession of personal capital, are surmountable by the best men; and since they give rise to modest ambitions, are most beneficial in a society organised on the basis of reward. In so far as there is a ladder by which a man may rise in the social scale, it is the greatest stimulus to his own exertions ; while the desire to prepare his sons and daughters for a better position than he himself has enjoyed has often been a motive for lifelong sacrifice of present enfoyment for the sake of a benefit that will accrue to the next generation. If this stimulus were withdrawn, there might easily be a reversion from the activity of modern life to the comparative torpor of the Middle Ages. From some points of view that might be desirable, but it would not make for economic vigour or material prosperity.

(c) If we look more specially at the artisan class, we shall find that there is great difficulty in even attempting to compare the reward of the industrial labourer in the thirteenth century with that which goes to him in the present day, as the circumstances are so entirely different. The Cambridge shoemaker of the thirteenth century had a very small market to cater for, and the authorities were able to keep the business of supplying it in the hands of a few 
neighbours. The craftsmen had no reason to apprehend competition from without; pressure was put upon them to supply good quality, and they were frequently allowed to form themselves into a craft-guild for this purpose; each one had a household, and might be assisted by a journeyman or two and an apprentice, but these men had not much opportunity of starting a business on their own account, and continued to form part of the master's household, sharing in the food that was provided, and receiving in addition regular pay that did not vary from year to year. Under these circumstances, it was possible for a craftsman consciously and deliberately to pursue the policy of maintaining the rate of reward by limiting the amount supplied. This was infurious to the customers; and if carried too far, would call for the intervention of the mayor, who would take steps to ensure that the prices charged should be reasonable; but the policy itself did not meet with the disapproval of the authorities, who were anxious that the householders might be prosperous, so that they might pay their quota of rates and help to make the contributions which were due annually from a corporate town to the king. No serious attempt was made to push trade or develop business, but only to carry on each calling according to the standard on which it was organised, and to maintain the habitual rate of reward. According to this policy, the conditions of the producer were allowed to be the first consideration, and the customer had to pay a price at which these conditions could be regularly maintained.

The policy of English merchants, who engaged in foreign trade and in exporting English commodities to foreign countries, was based on the same ideas. They did not attempt to push the trade, but to limit the amount supplied, so as to keep up the price paid by purchasers in foreign towns. The whole system of trading by regulated companies was organised with this object; careful arrangements were made that no member of the company should 
deal on terms which spoiled the market for his associates; and the company regulated the total amount of export for each year, so that prices might be maintained. This policy also had, on the whole, the approval of the authorities; in the time of Edward III. they limited the price at which wool should be exported, ${ }^{1}$ as it seemed more economical that Englishmen should have the wool to use at home, than that craftsmen beyond the seas should be supplied with materials at very low rates. Throughout the Middle Ages the interest of the purchaser, at home or abroad, was regarded as secondary; the interest of the producer, and the conditions of production, were taken as practically fixed, and they could be made the dominant consideration in adjusting the price.

In modern times this policy has been completely reversed; the interest of the consumer and purchaser has come to be put in the forefront, and the interests of the producer have been treated as secondary. The steps by which this change occurred can be briefly indicated, for the institutions, which gave effect to the mediæval policy, came to be the subject of complaint and were gradually broken down. In the fifteenth century we find frequent complaints by the purchasers as to the unreasonable ordinances made by the craft-guilds ; and these complaints were re-echoed by journeymen craftsmen, who were prevented from starting a business of their own, and could not secure a status of economic independence. Craftsmen, who settled in villages or suburbs, entered into successful competition with those who resided in corporate towns; and the whole system of exclusive trade privileges within the towns, and of substantial contributions from the towns, broke down at the Reformation era. Elizabeth attempted to reorganise the industrial system and created machinery by which the training of the workmen and the quality of goods should be maintained throughout the whole country; 1 Growth of English Industry and Commerce in Early and Middle Ages, p. 314. 
she provided facilities for preventing demands for unreasonably high prices; and the craftsmen in towns lost the power of so dominating the market as to prevent the competition of other dealers. They no longer retained a privileged position for setting a price and keeping the welfare of producers in the first place.

The struggle in regard to export trade came somewhat later ; it was carried on during the whole of the seventeenth century, and was maintained to some extent throughout the eighteenth and early part of the nineteenth. Interlopers succeeded in establishing trade with foreign parts, in spite of the efforts of the authorised companies to suppress their competition ; and manufacturers complained that they could obtain a far larger sale for their goods, and do much better business, if the restrictions were swept away. Hence competition, of buyers with buyers, and sellers with sellers, came to be the accepted method of determining prices both in internal and external trade. The producers had lost the power of controlling prices in their own interest, and the purchasing public at home and abroad began to reap the benefit of the change. As this process went on, a new policy for attaining success in business was devised; it became clear that it was necessary to push trade by getting a larger and larger circle of customers. The obvious means of attracting custom was by offering goods at low prices ; and as time has gone on, an enormous army of commercial travellers has been organised, in order that manufacturers may secure orders, and immense sums are spent in appeals to attract the custom of the public by means of advertisement. The effort to manufacture on a large scale, and therefore at less expense, has led to the transformation of business in many ways, and the crushing out of those who could only manufacture on a small scale. It has all come about under the new policy of trying to cater for the requirements of the public, on the most attractive possible terms and therefore at the lowest 
prices, and of allowing the conditions of work and rate of reward to adjust themselves as best they may to the conditions of price.

The capitalist, whether as merchant or manufacturer, is the medium through which this new industrial policy is carried out. He is a voluntary agent, since he undertakes this work of his own free will ; but he is not a free agent, in the sense that he can control prices, or pay wages, exactly as he likes. The limits within which he is free to exercise any considerable discretion are very narrow indeed. Prices are determined by supply and demand; he has comparatively little power of limiting supply ; and the best hope of maintaining, or increasing, the reward of those engaged in production, lies in stimulating the demand. The only method of doing this, which can be successfully pursued as a regular and constant thing, and without injury to any of the parties concerned, is that of maintaining the highest possible degree of efficiency, and continually endeavouring to readjust the methods of production and the organisation of business, so that the public shall be served with the best possible article at the lowest reasonable price. Since the middle of last century, the desirability of pursuing the economic policy, which regards the interests of the consumer as of primary importance, has been accepted in this country as almost axiomatic. The working classes, who have little money to spend, are eager supporters of low prices; as they desire to get as much as they can for their money, without giving much thought to ulterior consequences. The advisability of endeavouring to cater for the public on the best possible terms is not likely to be seriously called in question, but there may be good grounds for trying to modify the action of this principle in particular cases, especially when political reasons come into play. So long as this principle holds its own, the prosperity of the country can only be secured by the general adoption of the methods of business which it demands. 
The plans for carrying out this policy, which are sometimes adopted, may, however, be very infurious ; attempts may be made to push business by methods which are inconsistent with the permanent well-being of a trade. Prices may be lowered by offering goods of inferior quality, though this is likely before long to have an injurious effect on the market for wares that are so good as to be really cheap at a higher price. On the other hand, the effort to organise business, with a view to cheap production, may be carried on in such a fashion as to press unduly on those who work for wages; employers are in a position in which they may be able to drive hard bargains both as to the hours of work and the rates of pay, ${ }^{1}$ and to pass on the risk of the loss, which arises from the fluctuations of business, to be borne by those who are thrown out of employment. In so far as the deterioration of the workman follows, such action is not in the interest of business success in the long run. These unwise methods of competition have been met, partly by agreements between capitalists as to the course which it was desirable to pursue, and still more by the action of artisans themselves. The fundamental aim of trades unions has been to maintain a higher standard of life, by securing both a standard day and a standard rate of pay; and thus to reintroduce and maintain definite conditions for the labourer, even under a régime in which prices are settled by competition.

It was almost inevitable that these conflicting views should give rise to struggles which have been carried on with much bitterness. The working classes of the country have never really abandoned this belief that it is possible to maintain higher prices, and the means of increasing the rate of reward, by restricting the supply. They are inclined to think that the capitalists could take this course if they chose, and to suspect that the unwillingness of masters to do so is due to mere callousness and greed of 
gain. They have been inclined to resist all labour-saving improvements, as the workmen in the cloth trade protested against the use of gig-mills, ${ }^{1}$ and the women of Suffolk organised opposition to spinning fennies. ${ }^{2}$ The rules which have been made by some unions have operated to prevent the master from organising the labour he employs in what he regards as the best possible way; hence their continued reliance on the mediæval policy, of maintaining reward by limiting supply, has led them to disregard the supreme importance of increased efficiency in business, even when they have not consciously opposed it. The capitalists, who are thorough-going adherents of the modern commercial policy, can hardly help regarding the surviving influence of mediæval ideas as exceedingly mischievous; and they are apt to stigmatise the conduct to which it gives rise as utterly ignorant and almost criminal. Bitter as the struggle has been, and great as is the suffering it has caused, there is some satisfaction in seeing that it has arisen out of conflicting views in regard to business methods. There is hope that the conflict will be allayed as further experience gives us clearer views as to the policy which, in the present circumstances of the country, is most likely to promote the welfare of the community.

The organisation of the great trades of the country, on a large scale, has forced the leaders of the men's unions to look beyond local conditions, and to endeavour to consider the condition of certain branches of industry throughout the country as a whole. This is an important step towards recognising the impossibility of seriously attempting to maintain favourable conditions of reward by limiting the output. While restriction may answer to effect a reduction in the fluctuations from which business suffers, it cannot be an important element in maintaining our trade against

1 Growth of English Industry and Commerce in Modern Times, p. 661.

2 Ibid., p. 654. 
foreign rivals. If this is to be done, the union leaders must realise their obligation to take a part in endeavouring to maintain the industry of the country in a high state of efficiency, and must be prepared to co-operate heartily with the employers in aiming at this first essential to continued industrial success in the modern world.

(d) When labourers are successful in securing more favourable conditions, or a higher rate of reward, in a trade in which the employers have no monopoly, their profits are likely to fall. ${ }^{1}$ Every employer will endeavour to recoup himself for the additional outlay, and will try if possible to increase efficiency, by declining to employ any but the most efficient workmen. If the union insists on enforcing a higher rate of pay, the masters are unlikely to continue to employ men who are past their best, and are not worth this high rate of pay. Since the liability of the employers for compensation for accidents has been established, they are less willing to take on men who are either careless or stupid, or who from any other reason are likely to contribute to the occurrence of an accident. In this way, an effort to raise the standard of comfort unduly may easily lead to the weeding out of many men, who are unable to get employment in their own calling, and who cannot adapt themselves to anything else. On the other hand, the employers may take another line and try to recoup themselves for the extra expense by raising prices to the public. This may be a difficult course, in consequence of the possibility of importing the article from countries where it is produced under different conditions ; in any case it is likely to lead to a reduction of the demand, and in consequence to the employment of a smaller number of hands. In one way or another, the attempt to secure an inflated reward-that is to say, a larger rate of reward without any alteration in the methods of productionin a trade in which there is no monopoly, is likely to lead

I See below, p. 124. 
to the dismissal of the less efficient workmen, or to the reduction of employment generally:

When the increased reward of labour is accompanied by an increased efficiency of labour, no incidental evils are likely to ensue, as production will be maintained or increased and the trade may expand. But an inflated reward for labour is likely to react unfavourably on the condition of the working classes. In its immediate results it may be similar to the changes caused by the introduction of labour-saving machinery. There is likely, in the first instance, to be less employment available. But since the introduction of machinery may mean cheaper production, and a consequent expansion of trade, it is quite likely that the displaced labour may be reabsorbed as the trade expands. On the other hand, an inflated reward for labour does not lead in any obvious way to the expansion of trade; there is no likelihood that any opportunity will occur for reabsorbing permanently the labour that has been thrown out, in consequence of the granting of such demands. It may be impossible to say beforehand what demands for an advance ought to be conceded and what ought not: but the course of events decides the issue: where unemployment is increased through the granting of a demand, the demand is thereby condemned as unjustified.

(e) There has, on the whole, been an improvement in efficiency during the last half century, and the habitual standard of comfort among the artisan classes generally has undoubtedly improved; but there are certain industries in which this is not the case, and in them starvation rates of pay have become the rule. The sweated industries are for the most part a curious survival of an element of mediæval life under conditions in which its character is entirely changed. The sweater is in many ways analogous to the craftsman of the Middle Ages, who had the whole organisation of the industry under his personal control; but with this fundamental difference, that the craftsman had 
much power of fixing the price, while the modern sweater generally caters for customers who are apt to be entirely guided by considerations of cheapness. In many cases the sweater is partly a labourer, and partly a small capitalist; he is prepared to carry on his business at less than the ordinary rate of profit and at less than the ordinary rate of wages, since he draws his living partly from one and partly from another. He may be a workman who prefers, if possible, to work at his trade on his own account, with some subsidiary help. He may, in other cases, be a middleman who is ambitious to have a business of his own, and sees a chance of doing so by starting some manufacture for which little expensive capital, fixed-in machines and buildings, is required, but which can be carried on by obtaining the services of persons whose labour is not highly skilled, and who work in their own homes. The ranks of sempstresses are recruited from those who are thrown out from women's employments of. any kind. Just because the number of those who are glad to get work of some kind is so large, they have very little opportunity of agreeing together to drive as good a bargain as possible. Rates are forced down, not necessarily from eagerness to grind the faces of the poor, but merely because acceptance of offers to work for the lowest rate of hire is the simplest method of selecting among a crowd of applicants. On the one hand, the public desire for cheapness tends to the lowering of prices to unremunerative rates; while on the other, there has been no available means of checking the power of driving hard bargains, and no opportunity of attempting to maintain a standard of life. Here the effects of competition are seen at their worst ; but even in this case it must be remembered that the sweater is only to a very small extent a free agent in the manner in which he carries on his business. The influence of competition is too strong for any individual to be able to defy it altogether. The phenomena of sweating, in whatever way it may be possible to deal with them, are a 
standing warning against the dangers which are inherent in unregulated competition; and a proof that even the principle, of treating the requirements of the purchaser as supreme, may be carried so far as to lead to the serious injury of the producer. The underlying cause of the evil is certainly to be found in the undiscriminating preference of the public for that which is low-priced.

\section{The Profit on Capital}

(a) The income which accrues to the capitalist in the form of profit is variable and uncertain; if we leave out of account the large rentier class, who draw dividends, and fix our attention on those who are actively concerned in business themselves, it is true to say that the dates when money will come in, and the rate which will be received, are quite uncertain. The landlord expects to be paid at Michaelmas, and he has bargained to receive a definite sum. The clerk draws his salary quarterly, and the artisan gets his wages weekly, and each can tell beforehand the amount that will be due to him. But the merchant and the manufacturer are not in the same position; for some months or years, trade may be so bad that there is no profit at all, while other periods may be extraordinarily successful, and those who are able to take full advantage can reap enormous gains. The uncertainty, which affects all human affairs, is specially characteristic of every sort of commercial and manufacturing business; this must always involve risks of loss as well as prospects of gain; there must be an element of speculation, which has some affinity with gambling, and the men who engage in it must have some enterprise. The landlord lets the tenant have the use of his land, and if the tenant does not pay, he can sue him ; the artisan works for the master, and if his wages are not properly paid, he can go into court to recover them. But the capitalist does not render a specific service to 
specific people, and he cannot claim a reward which can be enforced in the courts of law; he simply endeavours to meet the requirements of the public and cater for their wants ; the service which he thus renders is requited very indirectly, and through a large number of intermediaries. Hence we can see the precise nature of profit; it is the difference between the outlay which the capitalist makes in carrying on his business, and the receipts which come in from his business. If he is a manufacturer, he must pay what is needed for repairs, replacement of machinery, materials, wages, and salaries-including an allowance for his own time and trouble as manager-in order to keep the business going, and he receives money by the sale of the product: the amount by which the receipts exceed the outlay is the profit on his capital.

In so far as the manufacturer fails to meet the public taste, and has his goods left on his hands, or sells them at a loss, his outlay probably exceeds his receipts, so that there will be no gain at all; and further, he looks to the sales to replace his capital, and if sales fall off seriously, his capital is eaten into and reduced. The announcements of bankruptcies in every issue of the London Gazette show what an enormous number of capitalists each year fail in their endeavours to meet public requirements, and not only carry on business without making anything by it, but lose their capital altogether. The capitalist merchant renders services to the community by giving access to other markets, or by assisting production; and, if the service he offers is not appreciated, he stands to lose. The rate of profit is likely to vary on every transaction; sometimes it is a minus quantity, sometimes it is very large. The rate of profit is so variable that it can hardly be quoted from week to week; but over any period, such as a year or more, there is an average rate. The competition of other capitalists will prevent any man who has hit on a successful enterprise from enjoying, for any great length of time, 
profits which exceed the average. Capital is not likely to be replaced or reinvested in enterprises which yield less than the average rate of profit, and a diminution of the quantities supplied may lead to an improvement in price, and thus bring up the profit again to the average rate.

Those enterprises which, at any place and time, are most successful in meeting public requirements, are the undertakings which yield the largest return; and men who are engaged in them are anxious to obtain the command of additional capital as easily as possible, so as to be able to take advantage of the high rate of profit while it lasts. Such chances may open out very quickly in commercial pursuits ; while the manufacturer will also desire, at times, to obtain additional capital in order to reorganise his business, or to enlarge the scale of his operations, in the hope of making reductions in the cost of production and the rate of outlay. Hence prosperous men of business are often anxious to borrow capital, for a time, or for a long period. The borrower offers a definite rate of return, to be paid at regular intervals as interest, since he believes that he can use the borrowed capital to advantage, and make such a profit from it, that, after he has paid the interest, he will have a substantial gain left in his own hands. The expansion of the power of borrowing capital, either through banks, or from private individuals, runs through the whole of modern business. It makes for the extension of business and the increase of employment, and is thus advantageous to the public and to the prosperous men who borrow ; while it also gives good opportunities to many people to find remunerative employment for their savings. Many persons have neither the enterprise nor the knowledge that would be requisite to induce them to face the uncertainty of business, and their money might lie idle, and fail to bring them any income, unless they were able to put it out at moderate interest which they can count upon receiving with practical certainty. 
(b) The advantages of being able to borrow or to lend at moderate interest are, to our minds, so obvious that we have great difficulty in sympathising with the condemnation of interest-the bargaining for gain for certain on secured capital-which was enforced all through the Middle Ages, and which still found sympathisers among playgoers when the Merchant of Venice was put on the stage and Shylock was held up to scorn for his 'interests.'

The popular conception in the Elizabethan age, of a man who let out his money at interest, was that of an oppressor who was able to take advantage of the necessities of other people. He did not engage in the uncertainties of trade, or make ventures across the sea, but secured himself as far as possible against any risk of loss, and while avoiding all risk, he bargained not only to share in the profits, but to get gain for certain, even when the enterprise was a failure, and the borrower had not got any gain but had besides lost his capital. Such a Shylock showed no enterprise, and took no risks he could help; but he went on gaining steadily all the time, and he attained a position from which he was able to prey on the necessities of better men. But the picture was ceasing to be true : even at that time, the borrower was generally the wealthy man, who was willing, for a stated sum, to share his opportunities for gain with the man of comparatively small means. The ordinary conscience failed to see that there was any real risk of extortion in such a transaction; and the objection to interest, or moderate usury, was swept away as a mere pedantry. The law of the land was content, in 1624, to prohibit excessive interest, or 'biting usury'; where excessive rates were demanded, it might be assumed that the lender was taking advantage of the necessities of a poor man to drive a hard bargain; but it seemed that under the new conditions of industry and commerce, and with expanding trade, moderate interest was likely to be fair, as between man and man, and that there was no 
longer any reason for the law of the land to prohibit it altogether.

There had also been changes in administrative practice which tended to render the mediæval view anachronistic in Elizabethan times. While feudal aids and such occasional demands for contributions to royal necessities were in vogue, the taxpayer was in danger of finding himself suddenly confronted by a requisition for the payment of a large sum which he could only obtain by borrowing : hence the lender could make terms with a man of no great wealth, who was reduced to straits by a sudden emergency. When regular taxation became more developed as a source of revenue, the administrators were often anxious to get possession of the money at once, before the tedious process of collection was completed; borrowing in anticipation of revenue was a constant practice, at all events in the seventeenth century. Thus it came about that the powerful tax-receiver, and not the impoverished taxpayer, was likely to be the borrower in the modern system of finance ; and from this point of view also, the danger of extortion was much less serious than it had been in Angevin times. There did not seem to be any likelihood of private injury arising in connection with the practice of lending on moderate interest; and consciences were not stirred by any doubts as to whether a proprietor was justified in shirking responsibility for the use made of his money. ${ }^{1}$

(c) At the same time, it is not clear that the change has been beneficial to the community generally. The opportunities for trading on borrowed capital enable the dealer, or manufacturer, to expand his business rapidly; and sudden expansion is often followed by overtrading and a long period of depression. These sudden fluctuations give great opportunities for particular men to make fortunes, but they are not favourable to a steady and healthy development, and they are often terribly mischievous to

1 See below, p. 192. 
the working classes. Further, the facilities for borrowing, which might have enabled landowners to develop their estates, have sometimes been used in building up extravagant residences, or in other forms of unremunerative expenditure, so that many estates have been heavily burdened, and agricultural progress has been delayed. The facilities which nations and towns enjoy for raising large sums on the assignment of taxes, or the security of rates, have also been much abused. The huge armaments, with which the great powers of the world are equipped, are extravagances in which nations would have been much less likely to indulge if they had been unable to borrow; and the accumulation of national and municipal indebtedness is exercising a very heavy pressure on the payer of taxes and rates. It is at least plausible to argue that the modern practice of borrowing, and the whole system of credit which has grown up in connection with it, is responsible for some of the most regrettable features of modern society, and that it would have been a good thing if the ecclesiastical authorities under James I. had been able to enforce their censures, ${ }^{1}$ and to prevent the new developments of trade and of banking from taking place.

While I have great sympathy with this opinion, ${ }^{2}$ and feel in regard to many of the evils of our modern industry and commercial system that prevention might have been easier than cure, I do not feel satisfied that, even if we could do so, it would be wise to abandon the use of such a powerful factor as credit has become, because of the incidental evils that have arisen in connection with it: rather than discard it altogether, we may do well to set ourselves to use it prudently. Credit is a powerful instrument for the production of wealth; it gives the means of procuring capital and setting labour to work; it enabled the government to

1 Canon cIx. of 1603 . See also 21 Jas. I. c. 17.

2 The Alternative to Socialism in England, read before the Cambridge Economic Club, 1885. 
steer the British nation successfully through the great struggle with Napoleon. Progress is being made in understanding how to deal with it wisely. The eighteenth century acquired much experience as to the nature of credit, and the conditions which are necessary to give stability to the banking system; and the periodical commercial crises, which characterised the first threequarters of the nineteenth century, have not recurred so regularly as to confirm the impression that they are inevitable. The supervision which is exercised by the Local Government Board over municipal borrowing is a wholesome check to corporate extravagance. These considerations seem to show that the credit system need not be regarded as an untameable monster, but as a great economic power which can be brought under rational control and be wisely directed. In so far as this is the case, it is not only advantageous to individuals but beneficial to the community as well.

(d) In so far as gain accrues to the capitalist because of a real service rendered to the public, it is legitimate profit, and the fair reward of successful enterprise. There have been cases in which capitalists have tried to increase profits by diminishing the outlay, so as to leave a larger margin between expenses and the receipts from sales; and this diminution of outlay has brought serious pressure to bear upon the labourer $;^{1}$ but the gains of the capitalist, when they are not earned by service to the public, are more likely to be obtained at the expense of other capitalists. The competition between capitalists is keen, and there are many cases where all of those engaged in a trade have been seriously damaged by the reckless speculation of one or two men, who have 'cut' prices and have rendered the trade unremunerative for a time. In much modern business, deliberate efforts are made to establish a corner, and so to place rival traders in a position in which they can be

1 See above, p. 105. 
severely squeezed by more acute rivals. These speculative movements are injurious to the public, inasmuch as they introduce arbitrary fluctuations of prices and irregularities in trade; but the direct loss falls, not on the public at large, but on those members of trading circles who have been unable to meet their engagements. Market competition may be carried on as a sort of war in which the weak go to the wall, and the spoils fall to the victors ; and it is probably almost impossible to prevent competitors from having recourse to such tactics, although they lead to a disturbance of trade and a waste of capital. There is also much outlay that does not seem to serve any good purpose, so far as the public are concerned, in pushing the wares of one firm against those offered by another. The various forms of soap and of mustard, which are largely advertised, are all good enough for public requirements, and there is no particular advantage to the community in the costly means which are taken to create a demand for the wares supplied by one firm, rather than for the article recommended by another. The competition of capitalists with capitalists involves a great deal of destruction of capital, when traders are ruined by reckless competition, and a great deal of unnecessary outlay and therefore of waste.

This waste is an economic rather than a social question; it occurs at the expense of men of enterprise, who can hardly claim the protection of the State against oppressors, and who can obtain redress if they have been fraudulently treated. At the same time it is a waste, and improved organisation may do much to reduce and prevent it. The waste which arises in connection with advertisement and the competition of retail traders, is greatly reduced by the introduction of the co-operative principle, as it was put in practice by the Rochdale Pioneers. ${ }^{1}$ By trading for a definite market it was possible to suit the requirements of customers with less leakage, and the system of accumulating

1 J. S. Mill, Political Economy, Iv. vii. \& 6, p. 784. 
discounts on purchases proved a particularly convenient method of saving. The various forms of co-partnership, from the colliery experiment of the Messrs. Briggs ${ }^{1}$ to the proposal made by Sir Christopher Furness, ${ }^{2}$ tend to effect savings in supervision, to insure against the interruption of business, and to reduce outlay. On the other hand, the combinations in Trusts practically exclude hostile competition from some of the great departments of productive industry. On all sides the growth of organisation is going on ; and as it advances, the sphere which is available for reckless and wasteful competition is narrowed. Even in such a case as that of the Standard Oil Company, where a great company was built up by most high-handed and unscrupulous methods, ${ }^{3}$ it is not clear that the public have been worse served than they would have been under a competitive system.

(e) There are many cases where it appears that the wastes of competition can be got rid of by municipal or national enterprise, in undertaking some particular kind of business. It is obviously advantageous, from the civic point of view, that the tramways, electric lighting, gas and water supplies, which involve interference with the use of the public thoroughfares, should all be in the hands of one responsible body, so that there may be the minimum of interference with traffic in laying down and maintaining the systems of supply ; even if they could not be worked so remuneratively under municipal as under private management, there would be some advantage in having them carried on as public affairs. In all probability, however, there might be a saving; for one thing, a municipality is likely to be able to borrow on advantageous terms, and to obtain the use of capital cheaply; and in the laying down a large fixed plant, such as is necessary for a gas or water supply, the element of capital enters largely. On the other hand, though a

1 J. S. Mill, Political Economy, p. 771.

3 Ida M. Tarbell, History of the.Standard Oil Company.

2 Times, 8th October 1908. 
supply of pure milk may be very requisite for the welfare of the community, ${ }^{1}$ the method of delivery, from door to door, renders the trade less appropriate for town authorities to take into their own hands, while the business involves much personal supervision in all its details ; and in securing that this should be regularly and constantly given, the municipality would be at a positive disadvantage, as compared with private persons each managing a business of his own. In such a case the best results can probably be maintained by private enterprise, working under public inspection and supervision. Where the work is done better, or at less expense, and public requirements are better met by municipal trading than by private individuals, municipal enterprise may perhaps be preferred; but where private enterprise is doing the work well, there is no good reason for attempting to transfer any branch of business to the local authorities. The onus probandi in any particular case, and the proof that there will be an economic or social gain, lies with those who wish to oust private enterprise and substitute authoritative control.

It is a matter for careful consideration then, whether a municipality is wise to enter on some department of trading, even when it will have the whole work of supplying local requirements in its own hands-as in the case of gas or tramway service. The case is quite different where the business is so large that the local authorities have difficulty in taking over the whole of it, and merely enter into competition with private persons; this they must do if they are content to aim at supplying some limited part of the local needs. In competing with private persons, municipalities are able to bring a good deal of indirect pressure to bear in their own favour; while they have the ratepayers' money behind them, and are not forced to be at pains to work at a profit. It may be argued, that the municipality

1 'Report of the Royal Commission on the Poor Law,' in Parliamentary Papers, 1909 , p. 795 . 
ought, even at the risk of loss, to clear out insanitary property and build decent accommodation for the poor, while private enterprise in providing houses is hampered by the regulations laid down by the authorities in regard to new buildings. Under such circumstances, there must be very great risk of financial loss on the part of any individual, who might have been otherwise prepared to erect cheap houses as a speculation. If builders feel that they have to compete against municipal philanthropy, they are less likely to set about building houses at their own risk; the municipality may easily check private enterprise, and then find that the problem of overcrowding is more and more difficult to deal with. The main point, in relieving overcrowding, is to supply a sufficient number of houses to accommodate the population as it continues to grow ; and in this, private enterprise has, on the whole, been very successful. So long as this process goes on, congestion is not likely to be increased, and the overcrowding in particular streets and tenements can be gradually dealt with. More drastic measures need not necessarily produce a beneficial result that will be at all permanent, and that is not counterbalanced by an increase of the mischief in other districts. Occasional interference, in the sudden sweeping away of some rookery, is only likely to diffuse the evil of overcrowding, not to eradicate it; if the accommodation provided in the houses rebuilt on the old site does not serve for so many people, even though the quality of accommodation is better, and it is let at an unremunerative rate. In so far as it is possible to provide, on a sound financial basis and in large numbers, houses that meet the requirements of those who do not belong to the most poverty-stricken strata of society, the pressure in the congested districts may be relieved indirectly, and insanitary property can be destroyed without the danger of effecting more harm than good. The management of tenement and cottage property, the collection of rents, and 
the evicting of destructive and disreputable tenants, is a business which cannot be done more effectively by a public department than by private individuals, and there may be serious loss, both pecuniary and social, if it is negligently performed. The fundamental question is, as to the best means of providing regularly and steadily for a constantly increasing need. If there is hope that this can be accomplished in the future, as it has been in the past, by private enterprise, the municipality would be unwise in taking over the whole business of housing the poor. So long as any reliance is placed on private enterprise in the matter, it is probably wise for the local authority to content itself with supervising those who undertake to meet this requirement, instead of attempting to enter into occasional and partial competition.

(f) It is true that the progress of organisation appears to be reducing the waste which arises incidentally from the keen competition of rival traders. Competition, as has often been noticed, is often liable to be displaced by monopoly; and there is a very general feeling that, so long as a monopoly is allowed to remain in private hands, there is a danger that the public interests may be sacrificed with the view of securing larger gains to the monopolist. This was a very real danger under the conditions of trade which existed in England in the seventeenth century ; but under modern conditions it is quite likely that a man who has secured the monopoly of an article of common consumption, as has been the case with the Standard Oil Company, will find that he can use his monopoly to the greatest advantage by catering in the best way possible for the wants of the public, so as to attract the largest possible amount of custom. A monopolist who finds that his profit lies in serving the public well, may be trusted to use his great powers for the public interest as well as in his own. Further, it may be remembered that a great monopolist is never irresponsible; he is exposed to the most searching 
criticism from fealous eyes; every indiscretion in his private life, and any harshness in the conduct of his business, is likely to be reported far and wide, and to be made the occasion of agitation against him. The power of the State to regulate the monopolists who carry on the traffic between different parts of the country, or to regulate industrial monopolists by means of factory inspection, is very great. It is important that these powers should be strengthened, and rendered more popular with those concerned, by prohibiting the introduction of articles into this country which are produced under conditions that would be prohibited here. There are practical means of insisting that the public interests shall not be neglected by the private monopolist.

It appears at first sight that a State monopoly is certain to be exercised entirely in the public interest-that since it is owned by the people, it is sure to be worked in such a way as to benefit the people. But this is not necessarily the case, especially as there are different sections of the public. A part of the tramway system may be laid down and run at a loss; where this occurs, a portion of the travelling public obtain a benefit at the expense of the ratepayers generally. The population benefited may be a very deserving section of the community; but it is not obvious that this subsidy is given in the interest of the ratepayers generally. There are numerous ways, where municipal management comes in, by which the general interest may be sacrificed to the advantage of some one district. This is much less likely to occur where the whole area is catered for by private enterprise.

The manner in which customers are treated is apt to be rather different under State and under private management. When a monopoly passes into public management, persons who are conscious that they are government employés are not always so mindful as they might be of the fact that they are the servants of the public. The postal 
service and the railway service may be contrasted in this respect: there are not infrequent complaints of the manner in which post-office clerks continue their private conversation while some member of the public is waiting to have a telegram transmitted; there is rarely occasion for similar complaints at railway booking-offices. Further, when anything goes wrong, if luggage is lost, the railway companies take extraordinary pains to find it, and if they fail, it is possible to obtain redress. The post-office appears to content itself with acknowledging a letter of complaint, and promising to inquire how the mistake has arisen, but never holds out any hope of redress. It is not clear that in these minor matters the public interests are better attended to by public than by private monopolists. So long as the conduct of an enterprise is in private hands, the weight of authority is brought to bear in the interests of the public and to obtain redress; when the conduct of an enterprise is in the hands of municipal or other public bodies, authority is more likely to be used to conceal abuses and to evade criticism, even when the aggrieved. party goes so far as to have a question asked in the House of Commons.

This is the real danger in regard to municipal enterprise, and the conduct of any kind of business as a State monopoly. The administration of such a business is necessarily carried on in such a fashion that there are many opportunities for corruption, both on the part of the members of Town Councils who control the business, and on the part of the officials who administer it. English public life has attained a high degree of purity, while rcliance has been placed on private enterprise ; but even under existing conditions it is not carried on by men who are incapable of yielding to temptation. Instances occasionally occur where it is difficult for the sanitary officers to condemn property that is a discredit to the owner, because the owner is on the Town Council and can use his influence to ensure silence 
and so continue to draw an income ; or where a speculative builder is able to transfer to the ratepayers the obligation of making up the roads that lead to cottage property he has built; or where guardians can vote outdoor relief to their own tenants, and thus have good security for the payment of their rents. It does not need much imaginative power to depict how far municipal corruption might go, if the opportunities of pursuing personal advantage at public expense were more frequent, and less scrupulous men were attracted to enter public life, with a view to the chances of making it profitable.

\section{The Return from Land}

(a) The services which landowners have rendered to the community have differed very much from time to time. In English society, at the era of the Norman Conquest, they had the burden of different political responsibilities; much of the land was held in return for the obligation of rendering military service and of furnishing men for the defence of the realm. The traditional obligation to assist in the maintenance of roads and bridges which were necessary for military purposes, was not forgotten. Further, the landowners were responsible for payments of various kinds, and that they acted as the agents by whom contributions were made on special occasions to the royal revenue. Each manor was rated as a unit, from which a known payment could be obtained, when Danegeld was levied. In Tudor times, when the feudal organisation of society was ceasing to be effective, we find that the landed gentry served as the agents for many administrative purposes. The Lords Licutenant were responsible for putting down disorder; and the Justices of the Peace were not only concerned in punishing offences of many kinds, but in assessing the prices of the necessaries of life, and the rates of wages, as well as in making provision for the unemployed. Great 
pressure was brought to bear in order to insist that the country gentry should reside on their estates and discharge these duties to the State, rather than merely draw their revenues and pay attendance at Court.

In modern times landlords have been called upon to discharge very important economic duties in the development of their estates. The effective supervision of labour and the directing of industry, so that food might be obtained and that the soil should be as little as possible exhausted, had doubtless been the practice from time immemorial ; but in the Elizabethan age very little capital had been sunk in the land; a great part of England was unfenced, the buildings, including the mills, were of a very simple and inexpensive character, and very little had been done in the way of agricultural draining, though some considerable attempts had been made to preserve land from inundation by the sea or by rivers. From that time onwards, but more especially in the eighteenth and nineteenth centuries, landowners have sunk large amounts of capital in the improvement of the soil. The estate belonging to the Bedford family at Thorney in Cambridgeshire has been an extraordinary example of the improvements that have been effected by the wise expenditure of capital on the land, while the history of that estate shows conclusively how little the inherent qualities of the land have to do with the value of English soil for arable purposes. It has been at enormous expense that the land has been brought into and maintained in a fit condition for high cultivation. The return which goes to the landlord may be partly considered as of the nature of salary for the military and administrative services which have been incidental to their position. In the modern organisation of the State, these services are not nearly so important as was formerly the case, though it would be a great mistake to ignore them. But the main elements for which rent is charged are fiscal and economic. The landlord is respon- 
sible for the payment of very heavy taxation, and the demand for rent may be regarded as an attempt to obtain the repayment of some of this money by the occupiers of the land. The main element, however, is a return on the capital which has been invested in the land, and which has been necessary to render it fit for its present use.

(b) There are many different uses to which land may be put : it may be employed as pasture land, it may be taken up for arable purposes, or it may be used for building sites ; and it lies with the landlord to decide to which use he will try to put his land. In nine cases out of ten he will be very much influenced by economic considerations, and by the nature of the offers he gets for the land. If the public desire to use his land for building sites, it will bring him a much larger income than if they are merely competing for the right to use it as agricultural land, or as unimproved pasture; so that economic considerations, and the desire of the greatest reward, will, on the whole, determine him to use his land in the way which is most advantageous to the public; but this is not necessarily the case. In the sixteenth century the rent which was to be obtained from sheep-runs was very large, and there was a danger that opportunities for using land for tillage would be so greatly reduced as to cause a public danger, both from the diminution of the available supply of corn, and from the decline of the rural population. Various statutes were passed to secure the public interest from being undermined by landlords who were pursuing their private gain. ${ }^{1}$ It is also conceivable that a landowner, from some personal caprice, may prefer to devote his land to a purpose which is unremunerative to him, when he could obtain a large income by allowing it to be used in the manner that would best meet the public requirements. There are always likely to be a certain number of people in any community who are merely wrong-headed; but, on the whole, the private

1 Growth of English Industry in Early and Middle Ages, p. 529. 
interest of the landlord and the service of the public have alike pointed out some particular use to which any particular piece of land ought to be adapted.

The amount of capital required for developing land for different purposes varies very largely. The expenditure on rough pasture is obviously very small; the cost per acre of the necessary buildings, roads, and fences for arable cultivation is large; while a very great deal has to be done in the way of laying out roads and in providing sewerage if an estate is to be broken up into building lots. The proper development of land for this purpose is a matter of great expense, and the results may be very uncertain. If landlords are occasionally arbitrary, towns are sometimes extraordinarily capricious in their habit of growth. The town of Birkenhead was a conspicuous example of failure to realise the expectations that were entertained of its development at the time when the docks were constructed and the park laid out; while in other cases the character of a suburb changes suddenly, and residential property falls enormously in value or has to be let as tenements. In the face of these difficulties, it may often happen that a man who has land, which might be available for building purposes, has neither the enterprise nor the capital which is necessary to adapt it to this use. If he has the means of doing so, he will reap a much larger return than he can ever hope to get from mere agricultural land. The arbitrary withholding of land from its most remunerative use is not probably very frequent. Under the system of private ownership, with occasional compulsory purchase for special objects, the uses to which the land of England has been put have been modified from time to time; but the economic service of the public has been the most important determining factor.

(c) The reward which accrues to the landlord for his services differs from that of the labourer and of the capitalist in the mode in which it is paid. It is a residuary 
payment; the labourer obtains his wages week by week, the farmers compete with one another for the use of land, and probably render it difficult for any of them to make such a bargain that he obtains more than the ordinary rate of profit. What the landlord can count upon receiving is the sum that remains after the ordinary expense of labour and the ordinary returns on the tenants' capital have been defrayed.

The broad differences in rent are determined by the different uses to which land is put; but all farms are not let at the same rent per acre, nor can all building plots be disposed of by the mere consideration of their area. The reason why some land pays much and some little, though they are employed for the same use, is that some land is better adapted than other land for the particular use in question. There is practically one market for cereals and farm produce generally throughout the whole of England, as all prices are dominated by the rates quoted from London. If land is badly situated, and the produce can only be brought to the market at great expense, the residual payment, which goes to the landlord, will be small ; similarly, there must be a large proportional outlay on the crop which is raised from very poor soil, and therefore the residual payment will also be small in this case. But where land is both well situated and fertile, the expense is comparatively small in proportion to the value of the crops, and the residual payment will be very large. For each use of land there is a rate of return which suffices to pay the wages of labour at the ordinary standard of comfort, and to replace the capital of the tenant at the ordinary rate of profit, as well as to defray the share of taxation and the profit on the outlay necessary to fit the land for the agricultural use. Unless it can yield this return, the land is not remuneratively employed in this particular use. All land that is better, either because of the character of the soil, or the exposure, or the convenience for market, will produce 
crops at a lower rate of expense, and the residual payment which goes to the landlord will be proportionately larger. The competition of farmers with farmers tends to keep the rate of tenants' profits at a level; when a farmer has a lease he may make exceptional profits for a time, if there is a series of good years, but he may be unable to carry out the terms of his agreement with his landlord if seasons are bad, or the range of prices is unexpectedly low.

The partnership between landlord and tenant is so close that the effect of bad times will soon be felt by the landlord. He may be forced to make remissions of rent in order to retain a good tenant; and as the farms become vacant, the competition of landlords with landlords, in order to secure competent and substantial tenants who will do justice to the land, may bring about a considerable reduction of rents. When such a loss occurs, the landlord has no means of recouping himself; he cannot raise prices, which are determined in open market; he cannot bring any pressure on either the labourer or the tenant to be satisfied with a lower standard of comfort or a lower rate of profit; all that he can hope to do is either to manage the land himself, or to try to render a farm more attractive to tenants by sinking additional money in buildings and improvements. If he regards both those courses as likely to result in loss, he may be forced to try to adapt the land to some other use-to let it go out of cultivation and make the most he can of pasturage, of shooting rights, or from its advantages as a golf course. When the land is thus diverted from the use for which it has been prepared at great cost, there is a sacrifice, not only of the income, but of much of the capital which was employed in fitting it for its former use, and which may be of no real advantage for the new use. During the last thirty years of agricultural depression, the ultimate loss has fallen entirely upon the landed class, although a generation of labourers and of tenants 
each felt the pressure of the transition; as land ceased to be remunerative and went out of cultivation, there was less employment for rural labourers, and many of them have drifted to the towns and have not prospered there. Many tenant farmers have been ruined in the struggle to carry on a declining industry, but at the present day the standard of comfort of the rural labourer is higher than it was thirty years ago; the tenant who understands his business is able to make a fair profit, but the residual payment to the landlords has sunk to so great a degree that it may be estimated that this class has been subjected to a loss in capital value of from eight hundred to one thousand millions. In regard to any declining area or declining country, the ultimate loss has to be borne by the landlords as a class.

(d) There is, however, another side to this picture. In a progressive country where land is in increasing demand for uses of every sort, or in districts where land is in increasing demand for some particular use, the residual payment to the landowners is likely to increase constantly and steadily. With an increasing population, the value of all the land of an isolated country would almost necessarily increase; there would tend to be an increased demand for house room, and for food and clothing, the materials of which are furnished from the land; and there would tend to be keener competition among labourers and capitalists, so that neither the standard of life nor the rate of profit is likely to rise. The residual payment would therefore go to the landowning class, and the rate of reward would bear no direct relation to the economic services which they might have rendered. In this way there arises what is commonly called the unearned increment from land; it is not an increment which is due to any special graspingness on the part of landlords ; it is not obtained at the expense of other capitalists or of labourers ; and it is not the cause (but an effect) of high prices paid by consumers; and thus it does not diminish 
the vigour of any of the factors in economic life. ${ }^{1}$ The transference of all landed property to the State would not, under these circumstances, make any difference, so far as agricultural activity goes, as this increment would, in the supposed circumstances, be forthcoming. In an old and populous country there may be a check to the further development of business, through the high price which has to be paid for land; and the difficulty which manufacturers have in competing in neutral markets with manufacturers in a new country may press heavily; but the burden cannot be removed by any social rearrangement.

The term unearned is, however, somewhat misleading; the landowners have sunk their capital in adapting the land to its various uses, and by their foresight in fitting the land for its present purpose have earned a right to participate, at all events, in the gain which accrues. The cause of popular complaint is not, strictly speaking, that the increment is altogether unearned, but that the enterprise of the landlord in a progressive country is, in the long run, remunerated at a higher rate than the enterprise of other capitalists. The peculiarity of the position of the landlord is that, having a stake in the country, he and his family share, as other classes do not, in the increasing wealth or in the increasing loss of the community. In a declining country the loss falls most heavily on this class, and in a prosperous country the permanent gain ultimately goes to the landowners, who continue to obtain residuary payments on a larger and larger scale. The recent history of England has afforded numerous illustrations of both tendencies: agriculture has declined, owing to the cheap transport from the Western States, and the flooding the English markets with American wheat. On the other hand, the increase of population and the rapid growth of

1 A comparison of the conditions in India, where payments made to the State as landlord encroach on the profit of the tenant, and the unearned increment in private hands is negligible, is very instructive.-M. G. Ranadé, Indian Economics, p. 31. 
many towns have enabled the owners of urban land to obtain greatly increased rents, as building leases fall in. Some large landowners have been enabled to hold their own through the agricultural crisis, and to go on making improvements in their rural estates, because of the income they derived from town or suburban property. The Bedford property, which has been an example of unremunerated agricultural enterprise in the Fens, also affords an example of the immense wealth which may be derived from landed property in such a great centre of population as Bloomsbury.

(e) The large and steadily increasing gains which go to particular persons, through the accident of their inheriting property in districts where the population is growing, have struck the popular imagination. The favoured children of fortune may have done little or nothing themselves towards the development of the property. It is not necessary for them, as it is for most men, to display any energy or enterprise themselves in order to prosper, since their wealth comes, partly through the enterprise of ancestors, and partly through the progress of the community, in which they have such a large stake. Hence there is a widespread feeling that this exceptional gain should be treated in an exceptional way. It is admitted that, from its nature, rent is not exacted at the expense of capitalists, or labourers, or the consumers, but arises incidentally, and that it does not arise from personal exertion of any kind on the part of many landowners. Hence it appears that what they enjoy should really go to society at large. They may be said to have a 'pull' over the public; an increment goes on accruing to them, from century to century, as land in good situations rises in value. It seems to many people that the appropriating of future increments to the State would involve no loss to individuals, and that it could be carried out without any shock to property.

A practical difficulty may be mentioned in passing: 
it is very difficult to assess, in regard to any property, what the precise value is, unless the property comes into the market and a price can be quoted as one that was taken or refused. Where this does not occur, the actual value of the property is a mere matter of guess-work; but even if this problem can be satisfactorily settled, there can be no certainty in deciding on the causes of any increase. When the landlord has recently introduced improvements, there must be difficulty in saying what proportion of gain is to be reckoned as profit on the landlord's investment of capital, and what is due to the general progress of society. This again is mere guess-work, and if the guesses are wrong the result will be that the State lays a claim, not merely to the sum which has arisen incidentally, but to profit which is the legitimate reward of the landlord's enterprise, and so mulcts him unfairly.

Any suggestion for levelling down, and reducing the wealth of the very rich, is to many minds plausible, as it tends to remove the great inequalities in society. But the more important point to consider is whether the appropriation by the State of future increment would be really beneficial to the community. How would the change affect the vigour of national economic life? It is to be noticed, in the first place, that the wealth diverted from the landlords to the coffers of the State would not necessarily be employed so as to serve the public better than if it had been left in private hands. ${ }^{1}$ In so far as it was employed as capital, it might be used to some extent to promote certain sectional interests, and there is a danger that it would open up opportunities for administrative corruption ; public expenditure does not necessarily bring about benefit to the public as a whole. If a serious attempt were made to distribute the benefit throughout all classes, this could be best done by a remission of taxation; but the sums which would thus reach the pockets of the people, through

1 See above, p. 135. 
the reduced demands of the tax collector, would not necessarily fructify, or give rise to much increased saving of capital. On the other hand, it is probably true that a very large part of the increment, which goes to rich men, is employed by them as capital ; their pride and interest may alike lead them to improve their property with the means at their disposal. Those who are not only urban but rural landlords have thus the means in their hands of improving their country estates, and making them more fit for agricultural production. It is difficult to see that there would be any direct benefit to the community as a whole if this appropriation took place.

It is, moreover, highly probable that there would be a serious injury to enterprise in catering for the needs of the public. Large windfalls and great gains appeal to the imagination; they may rouse jealousy among those who have no capital, but they also make a most effective appeal to many capitalists to enter on undertakings from which indefinite future gain may be anticipated. Adam Smith noticed that the great prizes in certain professions rendered them very attractive, ${ }^{1}$ and that men were influenced in the choice of a profession, not by the average earnings, but by the prospects of obtaining high position. If this is so in a man's choice of a calling, it is still more strikingly the case in regard to the use of his wealth. The prospect of making large gains calls forth a great deal of enterprise. The success of those who promoted the New River Company in the time of James r., and the large price which shares attained, must have had a considerable effect in inducing capitalists, all over the country, to initiate schemes for improving a local water supply. This need would not have been so readily met at great expense by private enterprise, if the prospect of gain had not had all the attraction of indefiniteness, and thus appealed to the investors' imagination. From the nature of the case it is impossible to say

1 Wealth of Nations, Bk. I. chap. xi. 
how far this has operated, or to what precise extent the stimulus to private enterprise to make local improvements would be affected. But we are not at liberty to assume that it would be unaffected, and that private enterprise could be counted upon to continue to show itself as effective in carrying out far-reaching plans in the service of the public. Levelling down is plausible, but it is not likely to be really beneficial.

\section{Drastic Remedies}

(a) According to the tendencies which are at work in the present day, there seems to be a prospect that organisation will become more widespread and more complete, so that the waste from competition may be minimised. In some cases these organisations, in so far as they are likely to disregard the public interest on any point, can be controlled and directed by the authority of the State, while the direct organisation of industry by the State may be able to supersede private enterprise, in those cases where any public requirement can be best served by a department of Government. To many minds, however, these processes seem to be slow ; the incidental mischiefs, which arise in connection with existing conditions, appear to be very grave, and men are inclined to insist that the economic life of the country should be submitted to some more drastic treatment. The failure to remove the misery and evil caused by extreme poverty is taken as demonstrating the defectiveness of a system of social organisation, which permits so much suffering on the one side, and on the other gives the opportunity for the accumulation of such large fortunes ; the poor remain poor, while the wealthy are more obtrusively and more offensively rich. They urge that the whole character of society ought to be completely changed, in the hope of securing less inequitable results.

Many people argue that something of this sort is necessary in order to avoid the terrible waste in modern society. 
There is, for example, the luxurious expenditure, either personal or national, which is less beneficial to the community in the long run than the production of goods which are capable of being used as capital would be; this is a negative waste. In it may be included the reservation of large parks for private enjoyment, or any other instances of the diversion of land from the use that is most beneficial to the community. Besides this, and even more regrettable, is the waste of human ability. There are men of force of character, intellectual power and artistic taste, who never get a chance to show what is in them; while others, who could not be regarded from any possible standpoint as better men, enjoy positions of responsibility and trust. It seems as if the State would be more efficiently served if there were entire equality of opportunity, so that the best men, without respect to the accidents of birth, might be able to show what is in them and so come to the front.

With this object in view, it is proposed to do away with all private property in land and the other requisites of production. The State would become the sole landowner and the sole capitalist, receiving the profit on capital and the return and increment from land. The services which have hitherto been rendered by capitalists and landowners would be performed instead by salaried officials, who would employ the land of the country for those uses which were most beneficial to the public, and guide the enterprise of the community into the best directions.

(b) Such a proposal implies a veritable revolution, and the entire abandonment of the principle which characterises economic life at present. That is the principle of calling forth and directing private interests so that they may co-operate for public good. The function of the State is mainly that of guaranteeing the reward obtainable by private persons who compete with other private persons, and of putting down that which is proved to be injurious. 
The initiative in economic matters at present rests with the individual. If the proposed revolution were carried out, there would be a positive scheme, authoritatively devised, of what was best for all. The initiative in giving effect to this scheme would rest with the State. The remuneration to be assigned to each individual would be determined by the official estimate of his needs, if the principle of reward were set aside, absolutely and entirely ; or at any rate the principle of reward for individual excellence would only enter as a subordinate consideration in the fixing of salaries. There would be no appeal to private interest, and no effort to stimulate it by the offer of special reward. In this way a practical equality might be maintained; but it is not clear that State initiative and collective wisdom would serve the community more efficiently than private enterprise does at present. The time has long gone by since any attempt of the sort was made in this country, but enormous pains were taken by the Privy Council, during the reigns of Elizabeth and the first two Stuarts, to organise every detail of industrial life, apprenticeship, wages, food supply, quality of goods, foreign commerce, and the introduction of improvements in agriculture and manufacturing on national lines. ${ }^{1}$ Immense pains were taken, but the system gave rise to much criticism and was very unpopular. It may be said that the means of ascertaining the actual economic condition of the country, and of enforcing the decisions of government, are much more perfect than they were in the sixteenth and serenteenth centuries. To a great extent this is true, but it is also true that the economic organisation of society is much more delicate, and less susceptible of government regulation in all its details. The development of national resources is, to a very large extent, a matter of local knowledge, and the attempt to concentrate all the projects for local improvement in one centralised

1 Growth of English Industry and Commerce in Modern Times, pp. 26, 37, $46,92,285$. 
department would not be likely to result in an increase of initiative, or a more prudent consideration of local conditions. We can to some extent appeal to experience in this matter; public authority proved incompetent to carry out a much desired improvement in the condition of the Fens during the fourteenth, fifteenth, and sixteenth centuries. Repeated efforts were made, but without success. The work of draining the great level of the Fens was only accomplished in the seventeenth century when private enterprise was empowered, and encouraged by the State, to get to work. Immensely more skill and organising power is now at the disposal of the central authority, but it is not clear that an effective desire for public good is so strong that all reliance on the motive force of the hope of private reward can be safely abandoned.

(c) Under the proposed scheme the most effective motives to energy and enterprise of every kind would cease to operate; the rewards which have attracted men most strongly have not been merely pecuniary, but rather social. In many cases the pecuniary reward has been valued chiefly because of the incidental social advantages which it opened up. In a society where constant efforts were made both to level down and also to level up, so as to maintain approximate equality, there could be little distinction of class, and therefore no hope of rising in the world. Wholesome ambitions of many sorts would cease to operate; there would be no ladder by which a man could rise, because there would be nothing to rise to. Further, there would be little, if any, opportunity for a man to cherish an ambition for his children, and to try to give them a better start in life than he had himself; or in any other way to improve the social status to which they could aspire. All such efforts would be inconsistent with equality of opportunity. But the effort to maintain a position, and to improve it, has been the efficient cause which has called forth both energy and enterprise in the past. It is difficult 
to imagine that any corresponding factor could be brought into play in the future.

After all, the actual work, manual and administrative, must be done by individuals. If their energies are not left free play, but are guided authoritatively, there must be discipline and compulsion; this has never yet proved the best means of getting the most out of men for the public good. ${ }^{1}$ It might perhaps be hoped that the enthusiasm for maintaining and carrying on a state of society, in which equality was approximately maintained, would inspire men to do their best under the new order; but though little experience directly bearing on the point can be quoted, it is at least doubtful whether the population generally would be more contented under the new régime, or would be at all ready to make sacrifices of time and energy to maintain it. Condemnation to the routine of steady work, for no personal reward, and with no hope of improved conditions, might have a very depressing effect. At the present time, discontent is not entirely and wholly due to mere jealousy of others, who seem to be more fortunate than ourselves. Restrictions of any kind may rouse resentment; if a man or woman wants to live his own life, and be free to develop and express his own personality, the routine imposed by society may be as galling as the routine imposed by a master. The worst result of the agricultural revolution in the reign of George III. was that it deprived the peasant of any hope of rising personally to an improved position in his calling. The desire for personal freedom of movement, and the demand for freedom to use their energies for their own advantage, seem to have been the reasons why villeinage was felt to be a grievance, and the peasants revolted in 1381. A dead level of existence, when there is no hope of improvement or change, is not unlikely to make most men listless, and to render some others reckless. Neither one frame of mind nor the other is conducive to

1 See above, p. 82. 
regular and energetic work. Those who were selected for administrative positions might have a difficult task in obtaining such energetic labour that the wants of the community were well served in the present, while it is difficult to see in what way they would have any means at their disposal for making provision for improvement in the future.

(d) From the point of view of the maintenance of a healthy and vigorous economic life, ${ }^{1}$ it does not appear that the new order would compare favourably with the old; it may be thought, however, that some sacrifice of material prosperity would be worth while if a better social life were secured. So far as social life depends on opportunities for leisure and culture, it is unlikely that these would be increased, or would be more generally available, if material prosperity were in any way to decline. Some cherish a hope, however, that the tone and spirit of society would be greatly changed, that the irritation and jealousy which arise through individual competition would be allayed, that selfishness of every kind would be exorcised, and that a fraternal spirit would take its place. If such a change of character would be sure to follow, it would be worth while to make any sacrifice of more material wealth in order to purchase it; but the expectation is quite illusory. Racial differences are too deep seated to be readily merged in a sense of universal brotherhood. Strong affections for those who are near and dear may be enlarged so as to embrace a wide circle ; but the sentiment of universal brotherhood is vague. There would be no real fraternal spirit in the society, and it could not impress that spirit on its members. A scheme which looks mainly at the maintenance of equality, and the levelling down of rewards, is not really altruistic ; it demands sacrifices from others, but it makes no demand for self-sacrifice. It is, after all, an appeal to the self-interest of the masses of the people. A fraternal

1 See above, p. 81. 
spirit cannot be propagated among its members by a society that is merely held together for the promotion of interests. The co-operative movement was started under the influence of high humanitarian enthusiasms, but it has not been successful in educating the members generally into a disregard of their personal advantage and an absorption in the common good. There would be no necessary immunity from the same defects in a reconstituted society; and under the new order there might be much jealousy of those who were selected to fill administrative positions, and doubts might arise both as to their wisdom and their zeal.

The social revolution would let loose destructive forces, but there is little ground for hoping that it would show reconstructive power. At best it might be successful in reconstituting a society in which no one could be rich, but there is little reason to believe that a system which came into being under such auspices would render men either contented or unselfish. 


\section{CHAPTER I I I}

\section{HALF TRUTHS}

\section{The Problems of Life}

(a) The survey of national economic life in which we have been engaged may at least have served to bring out the fact that social problems are extraordinarily complex. They are really questions as to the maintenance of a healthy national life, and it is still more difficult to prescribe aright for the body politic than for the human body. If we are thinking out the conditions of a healthy man's life, questions of diet and air, of clothing and exercise, have all to be considered, and the reaction of the mind on the body cannot be ignored. When there is need to diagnose any case of disease, there may be much difficulty in seeing what has caused it, and how it has to be treated-whether surgical treatment is needed, or whether an improvement in general health will enable the patient to throw off the mischief. Something similar is true of the body politic; if healthy progress is to be maintained in society, a great number of different factors must be called into play, and it is important that none of these should be overlooked. We must also try to recognise how much the various forces at work differ in character: some lie outside the direct control of any human agency ; some can be exercised by human beings acting collectively as a State, while others can only be brought into play by individuals personally. All this must be borne in mind if we are ever to state any problems of social life correctly, and in order that we may 
begin to know where to look for a possible solution. But this process is tedious, and often seems to be unnecessarily roundabout. The evils lie on the surface, and obvious remedies appear to be ready to hand. It seems simple enough to meet the evil of unemployment by organising relief works, and we can thus avoid the trouble of considering whether the difficulty is accidental, or whether it is a symptom of some grave distemper in our national life. Alleviations may only aggravate the disease. There is always a danger of being satisfied with noting proximate causes, instead of inquiring into the potent influences which lie in the background; we may also be too easily contented with considering immediate effects, without looking ahead to try to estimate ulterior results. Prominent features and dominating forces attract our notice, and we are apt to concentrate attention on particular points, and to exaggerate their importance.

Such partial and one-sided treatment appears to be simple and direct, but it is apt to result in mistaken diagnosis and to lead us to rely on inadequate remedies. There is sometimes a temptation to exaggerate the powers of the State, for good or for evil ; and, on other occasions, we may neglect the limits within which individuals are free in existing society to determine on taking independent action for themselves. ${ }^{1}$ These are obvious dangers, but there is no simple means of securing complete immunity from them. It is only possible to bear them constantly in mind, and to be consciously on the watch against them.

Under these circumstances, there need be little surprise that so much current discussion of social problems is confused and confusing. Partial views of all sorts contain an element of truth ; the error begins in neglecting the limits within which each opinion is true ; but enthusiasts resent the suggestion that any limitations exist. If the enthusiast for a simple diet recognises that milk is a perfect food for

I See above, p. 117. 
babies, he is likely to reject all strong meat; if he regards alcohol as a poison, he will never use it even to save his life. The enthusiast for social reform is apt to indulge in similar generalisations; he is apt to insist that what is ever true anywhere must always be true; and that what holds good, within narrow limits of place and time, may be counted upon to hold good everywhere. In the purely physical sphere this principle of the uniformity of nature is one we habitually take for granted, and there seems to be no good reason for not applying it in economic and social matters as well. In dealing with social problems, however, we are not concerned with man by himself, nor with physical nature by itself, but with a social life that arises through man's struggle with his environment. In the moral sphere there is absolute right laid down as true for all time, but it cannot always be applied offhand in all the changing conditions of place and time; nor is man's economic position to be directly deduced from the physical order. Social life cannot be healthy if morality is set aside and physical prosperity is ignored; but neither morality nor physical science can, in themselves and alone, say a final word upon any of the issues. The relations between man and his environment are constantly changing, as man's knowledge of nature and power over nature, and ability to adapt himself to his environment, increase. Hence all the principles which we lay down with regard to social matters are only ' true so far as they go,' and within limits. They are true, but they are only half truths; and a truth which is half a truth may become the blackest of lies, because the untruth in it is so difficult to detect and to refute. It cannot be met by a direct denial, but only by a demand for modification and correction. The admission that there is an element of truth appears to give confirmation to the broad statement; while the demand for modification and correction may be discounted as mere pedantry. On this account the enthusiast, who maintains a half-truth in 
popular discussion on these subjects, occupies a position of considerable advantage.

(b) The best available means for guarding against the danger of generalising from a few instances is to be careful to keep as closely as possible in touch with actual experience, and to hesitate about relying on any principle which is merely deduced from indirect reasoning and is not confirmed by actual experience. In the life of the community, various forces - physical, collective, and personalare at work, co-operating with or limiting and checking each other. The factors which have been effectively operating over long periods of history, or throughout widespread regions in the present day, are likely to be of more relative importance than conditions which are local and temporary. The consideration of long periods of the past may help us to distinguish between temporary and ultimate results, and thus to form a sounder judgment in regard to the probable results of any course of conduct in the present. History never repeats itself exactly, and it cannot enable us to foresee the future with accuracy. It does not give us a basis from which we can argue with demonstrable certainty in regard to a new case; but it does offer results which are, at least, useful hypotheses, to be confirmed or rejected by fresh trial. Besides this, the study of the experience of the past furnishes means of criticism as well as suggestions ; it gives scope for the exercise of insight, and may be highly instructive with regard to social problems in the present. The educational value of economic science as a training of the mind is greatly due to the admirable assistance which the Classical School furnished, by their precise definitions and clear statement of their assumptions, to the absorption and co-ordination of new observations. There has been a tendency in recent times to adopt a system of analysis which is quite different from that of Adam Smith. Jevons and his school treat Utility, rather than Exchange-Value, as the fundamental conception of 
Economic Science. ${ }^{1}$ This treatment is apt to be one-sided, as it lays undue stress on consumption and enfoyment, ${ }^{2}$ rather than on developing the activities of economic life. Ingenious as this system is, it brings the subjective ${ }^{3}$ side into undue prominence, and fails to provide convenient instruments for dealing with the ordinary phenomena and conditions of actual life. By analysing the mechanical play of internal motive, we do not get a truer view of society than by considering the mechanical play of external forces ; we only habituate ourselves to less appropriate conceptions for grouping the observed facts of life. Refinements of theory may be pretty playthings; but the advance of knowledge can only come through the statement of hypotheses in a form in which they may serve to co-ordinate or be corrected by actual experience. This may help us to see the various phenomena of society in right proportions, and may furnish useful suggestions and weighty criticisms with regard to proposals for the future.

(c) The study of actual experience is necessary in order to get at the limits within which each partial truth is actually true, and therefore in order to make an accurate diagnosis, and it is also necessary in order to help us to judge how far any proposed remedy is suitable to the actual case. Changes in conditions do not produce the same results among all human beings alike. The precise phase and condition of human nature must be considered, in order that we may forecast the use they are likely to make of the opportunities afforded by increased wealth or leisure, or the manner in which they are likely to conduct themselves under more stringent compulsion. The attempt to make men moral by Act of Parliament may only result in bringing the law of the land into contempt, by demonstrating its futility to secure the expected results.

1 'Back to Adam Smith,' in Rise and Decline of Free Trade Movement, p. 205 .

2 Socialism and Christianity, p. 19.

3 Wisdom of the Wise, p. 19. 
It is of course true that experience of the past does not determine what is to be hoped for in the future ; to admit this to be the case would be to abandon much hope of improvement of any kind. But while experience does not limit our expectations as to what may be possible in the future, it does give us most valuable guidance as to what it is best worth while to attempt in the present. It points out the line of least resistance, and the course by which improvement may be carried on without giving rise to violent opposition. It is important to see what is practicable in existing conditions-how far what is old can be modified for the better, and what forces are at work to prevent the introduction of something that is new. Those who neglect the thorough empirical study of social phenomena, in the present and in the past, are in danger of giving their strength to the advocacy of some remedy that is inapplicable in present conditions ; such a prescription, if it did not prove inoperative altogether, might turn out to be mischievous.

The fact that many current principles are partially, but only partially, true, is one reason for the curious confusion which is to be found in much discussion on social subjects at the present time. Two half-truths do not make a whole ; and it is possible to be captivated by suggestions, each of which is plausible, but which are really incompatible. Modern economic progress has given us immensely increased power over nature, and it came into being as mediæval conditions were swept away. Many of us are inclined to admire and boast of the triumphs of engineering skill and the developments of commerce in the present day, and at the same time to pay a tribute of admiration to certain features in the life of the past, when economic conditions were different, when business was less strenuous and habits were simpler. In this, as in so many matters, we cannot have it both ways at once; there has been loss as well as gain in the course of progress; we may set ourselves to 
remove what is infurious in the present day, but it is a waste of time to attempt to do so by merely reintroducing what has been proved to be incompatible with modern conditions by the very fact that it has died out. The real test of any invention is whether it will work; and the national life, in the process of growth, discards what cannot be assimilated. Unless we habitually realise that social problems are problems of life, the results of our study of conditions and experience in other times and places will not help us in trying to guide the developments of national life.

\section{The Mechanism of Society}

(a) Those who have devoted themselves most enthusiastically to the study of social phenomena have not been able to keep this in mind; they have been too much inclined to look at society as a mere mechanism, not as a living growth. Since this method of treatment is partial, we cannot rely on it with confidence, if we wish to look far ahead; but it is sound so far as it goes, and we cannot hope to understand the working of society in the present in detail, unless we have recourse to it. Every social organism is a mechanism, though it is not a mere mechanism : a college crew is a mechanism, and it is the part of the 'coach' to train the men to work together in such a fashion as to produce the best result mechanically; but it is not a mere mechanism; such factors as health, and nerve, and pluck contribute to the winning of a race. The ' coach' must treat the boat as a mechanism, for the purpose of noting and correcting certain faults of detail ; but he ought to bear in mind that it is not a mere mechanism, if he is to get the best work out of all the men. For the investigation of details, and the accumulation of knowledge, it is necessary to think of human society as mechanical ; for many purposes of study, and for some suggestions of improvement, this point of view may serve; but with regard to all deep-seated evils 
and far-reaching changes, we must remember that mechanical readjustments will not suffice, and that the problem must not be merely viewed in its simplest form as mechanical, but as a question of health and disease in the life of society. Merely mechanical treatment is not really adequate.

The very success with which economic science has been cultivated during the last hundred and fifty years has rendered it difficult for those who devote themselves to this study to recognise its limitations, while the public have been even less able to exercise a discriminating judgment on its teaching. Sir William Petty and the other seventeenth-century writers, who tried to apply methods which were successful in physical science to the investigation of social problems, were anxious to get means of correct measurement of national progress, and with this object they paid attention to the balance of trade as a sort of mechanical test which indicated whether the country was progressing or not. The great advance which was brought about by Adam Smith was due to the fact that he made it possible to carry the mechanical conception much further, and to give much more accurate treatment of the progress of society, by deliberately confining his attention to a limited sphere. He carefully left political considerations in the background, though he never overlooked them and did not underrate their importance; he defined his subject as the causes of the wealth of nations, without professing to treat of any other aspects of the life of the community. His followers went further by assuming that the wealth of the nation was practically identical with the aggregate of the wealth of individuals, and by restricting their attention to the conditions which were most favourable to the increase of individual wealth. To give free play to the individual desire of wealth was apparently, and at all events for a brief period, the most effective way to add to the grand total of wealth available in the community ; and 
the mechanism of society would operate most easily and freely when built on these lines. The Classical Economists effected a decided advance by deliberately confining themselves to the study of society as a mechanism for producing material wealth. This proved to be a convenient method for carrying on thorough investigations in regard to industrial, commercial, and financial affairs. Much that was puzzling and mysterious in the eighteenth century has now been rendered explicable and clear; the introduction of accurate terminology has been an immense assistance, and progress is being maintained. The isolation of certain classes of phenomena renders more precise enumeration possible ; and the rise or fall in the value of the circulating medium can now be measured with such accuracy as to help us to see a little way ahead into some of the farreaching changes that are involved. The work of those who adopted the mechanical conception of society has been of the highest importance for all time, as they give us the means of co-ordinating experience and of accumulating accurate knowledge of society, in so far as it has this mechanical character; and it always must have this character, whatever else it may be as well.

(b) The Classical Economists were fully aware of the onesided and partial character of their treatment, and attempted in various ways to guard themselves against misunderstanding. Some of them endeavoured to maintain that the view of society as a mechanism, where each man was pursuing his own individual interest, was only adopted as a convenient hypothesis for purposes of study, and was not intended to be the basis of any recommendation in regard to the course which should be adopted. They have been very careful not to exaggerate the claims of a mechanical science of society to say the last word on the problems of life; and Professor Nicholson closes his masterly treatise ${ }^{1}$ with a reiterated warning on this point.

1 Principles of Political kiconomy, iii. 427. 
But the British Journalist and the British public have never been able to reconcile themselves to adopt this tentative and discriminating attitude to the teaching of economic science, and to accept it as true, but as only true within more or less narrow limits. They have sometimes hailed it with undue respect, as an authoritative guide that ought to be followed blindly, and they sometimes go to the opposite extreme and rail against it as a mischievous pedantry.

It is probable enough that the popular exponents of economic science were less careful in this matter than the great masters of the Classical School, and that some excuse was given for the dislike of economic science which found expression in the writings of Carlyle and Dickens. The public were inclined to suppose that economists advocated their doctrine, not merely as a scientific statement of the principles on which the mechanism of society works, but as a guide to the national conduct of affairs. The misunderstanding was excusable, from the persistent affectation of the economists in needlessly using the term 'economic law' ${ }^{1}$ this was naturally taken by the vulgar as being correlative to some economic duty; and the principles, which expressed the action of self-interested individuals, were interpreted and held up to scorn as inculcating selfishness. The habit, which was popularly condemned, of isolating the consideration of purely selfish interests, and calculating what will happen on this supposition, is not degrading; any philanthropist who wishes to make some project a thorough success must adopt this attitude of mind and try to view his scheme from a purely business point of view. If a clergyman is trying to start a games club for the boys in his parish, whom he wishes to encourage to play football in winter and cricket in summer, he is sure to consider whether it can be made to pay its way or not. Very likely he comes to the conclusion that, if the preliminary expenses were met, the club could be kept

1 See my 'Plea for Pure Theory,' in Economic Review, ii. 37-41. 
going by a payment of a penny a week from each member. $\mathrm{He}$ is likely to be willing to give, or to beg, money to start it, if he sees a fair prospect that it can be self-supporting. But possibly the boys complain that they cannot afford to pay a penny a week all the year round. 'The clergyman sees that the club cannot be kept up on a business footing, and that the self-interest of the boys is not strong enough to support it. He knows where he stands; he may think the results of fresh air and exercise are so important that he will subsidise the club, though it is clear that it will, under these circumstances, have less vitality than if it was independent and could stand on its own footing. He may think, on the other hand, that the boys should pay for their own amusements, and that there will be no healthy esprit de corps unless it is their own affair. The isolation of the business aspect enables him to come to an intelligent decision and to weigh the pros and cons satisfactorily; it sets the question in a clear light. In exactly the same way, there is nothing sordid or derogatory in examining national problems in a purely business aspect, so long as we are clearly conscious that it is only an inquiry that is preliminary to the decision, and that the national decision should be taken with reference to wider considerations as well.

(c) The doctrine of Economic Science is true and important, but only true within certain limits and conditions, and even the greatest of the economists have not always been able to bear in mind how narrow is the sphere, both in place and time, within which the most carefully stated doctrine is really to be relied upon with confidence, as true to actual life. Conditions are constantly changing, both in regard to commercial facilities and industrial processes, as well as in regard to the character and ambitions and adaptability of human beings. What we assume to-day, in regard to physical conditions or human agents, is always becoming out of date; the economist can only safeguard himself, in his forecast of the probable effects of any 
proposed changes, by the frequent proviso that he assumes that other things are unchanged. The economist cannot forecast what tends to happen with such certainty as the astronomer, or the physicist, or the chemist, or even the meteorologist. The economic expert is always in danger of supposing that the conditions he assumes are more permanent than is really the case, and of generalising too hastily from a few instances. Where he fails to guard against this tendency, and allows himself to assert that something must happen, he is using language which he has no right to employ; all he can say is that the result is likely to happen if he has taken account of the conditions correctly, and if the conditions remain the same.

This economic ' must,' whether standing baldly by itself, or wrapped up in verbiage about inexorable economic laws, was responsible for much misunderstanding and bitterness in connection with economic legislation throughout the nineteenth century. Those who are contented to view society as a mechanism are not competent to deal wisely with national life, even in its economic aspects. There have, again and again, been most regrettable results from the manner in which economists assumed the permanence of the conditions with which they were familiar. ${ }^{1}$ The economic pessimism which regarded wages as paid out of a definite 'wages fund' was practically true during some decades, say from $1820-40$; but it was a mistake to treat it as an iron law of wages, which must hold good under all conditions. ${ }^{2}$ The opposition of employers to the Factory Acts was stiffened, both in 1819 and in 1844, by economic doctrine as to the necessary effect of shortened hours on trade and wages. ${ }^{3}$ In Ricardo's time there was an excuse for treating economic rent as increasing mechanically, without either thought or trouble on the landlord's

1 Growth of English Industry and Commerce in Modern Times, p. 740.

2 lbid., p. 741.

3 Ibid., p. 775; Hutchins and Harrison, Factory Legislation, pp. 27, 88. 
part; but this doctrine has left an entirely unfounded impression of the actual English landlord and the contribution he is constantly making to the maintenance of the land in workable condition. Mill argued against attempts to provide allotments for the poor as an illusory remedy, ${ }^{1}$ and the careful Report of Commissioners ${ }^{2}$ as to the conditions in which it would and would not prove useful was allowed to drop. There has been no subject of public interest on which the economic expert has not laid down the law as to the manner in which the mechanism of society must work, while, time after time, economic life has demonstrated its ability to take on new functions and adapt itself to new conditions.

\section{Particular Aims}

(a) Since men of trained intelligence have been unable to make proper allowance for the treatment of social problems as if they were merely mechanical, there need be no wonder that practical men, who make no pretension to be dispassionate and scientific, should be inclined, according to their temperament or upbringing, to fix on some factor as essential to the welfare of society, and arbitrarily to relegate everything else to a subordinate position, or to neglect it altogether.

There can be no doubt that an insufficient supply of the ordinary food of the people causes very great distress in any community: it is natural to conclude that an abundant supply of cheap food must be the prime essential for national prosperity, and that it would be wise to sacrifice anything else in order to secure this boon for the masses of the people.

It is undoubtedly true that the food supply is a matter of supreme importance to the nation; since the Elizabethan age, when the economic life of the country was taken in

1 Political Economy (Ashley), p. 368.

2 'Report from Select Committee on Labouring Poor,' in Reports, 1843, vii. 
hand and regulated on national lines, constant attention has been given to it. The policy which has been adopted in one age has not always been found suitable for the requirements of a succeeding period; but, till the present day, the food supply has, generally speaking, been regarded as only one element, and therefore as a matter to be taken into account in connection with other measures for the welfare of the people, and not by itself. Under Elizabeth, there was still a tendency on the part of the landowners to divert land from tillaige to sheep-farming, owing to the high price which wool fetched, and there was danger that the home-grown supply would fall off, as arable cultivation did not pay well; the government aimed, at that time, not at lowering the price of corn but at improving the profit of the plough, ${ }^{1}$ by allowing the development of an internal corn trade $;^{2}$ while, at the same time, machinery was in operation for regulating wages according to the price of corn. ${ }^{3}$ A century later, at the time of the Revolution, efforts were made to keep prices ranging high, so as again to stimulate home production, by giving facilities for export to foreign markets; arrangements were also made with a view of avoiding serious fluctuation in the available supply, and therefore in the price, according as the seasons were good or bad; a plentiful supply with stability of price, not with a low price, was the aim of the policy of the time. Under the Corn Bounty system, and with developing opportunities of employment, labourers seem to have obtained wages which gave them command over a good supply of the necessaries of life ; the rates of pay were such that a high standard of comfort might have been maintained. From 1770 onwards, when England began to rely on imported corn, there was a great deal of dispute as to the policy which it was wise to adopt; considerable efforts were

1 John Hales, Discourse of Common Weal, p. 53.

2 Growth of English Industry and Commerce in Modern Times, p. 91.

3 Ibid., p. 38. 
made by means of bounties to attract an increased supply from abroad, but in the last decade of the eighteenth century the country reverted to the policy of stimulating home production. When the exceptional conditions created by the Napoleonic Wars were passing away, the Corn Law of 1815 was carried; it proved to be a singularly inept measure, as it prevented the introduction of supplies from abroad, while it failed to give a sufficient stimulus to increased home production. As general dissatisfaction increased, the policy of procuring cheap food came to be consciously formulated, as a desirable object for its own sake, in a way that had never been done before; though it is worth notice that Cobden carefully disclaimed this object, and argued that the removal of restriction would give a larger supply at the existing price. ${ }^{1}$ He knew that cheapness was not the sole consideration.

The policy of directing exclusive attention to the procuring of cheap food is plausible though one-sided; but it cannot be wise to leave the future of the food supply of this country entirely to chance. To past generations it seemed prudent, for political reasons, that there should be a sufficient food supply produced at home, so that the nation should not be dependent on possible enemies for any of the necessaries of national existence. It is now possible to pursue this policy over a far larger area, by giving encouragement to corn-growing within the Empire, and by being at pains to provide such facilities of communication as to improve our access to the large supplies which are available from countries attached to us by the most intimate political ties, and under the authority of the British Crown. It is to these undeveloped areas that the world must look for an increased supply of wheat; to strengthen our business connections with these areas is the best way to guard against the danger, in the near future, of a considerable rise in the price of food in this country. If we make no attempt to

1 Rise and Decline of Free Trade Movement, pp. 60, 175. 
take advantage of our present opportunities in order to make provision for the time to come, we are running a very serious risk, and gambling with the future not only of the country but of the Empire.

It is of course possible that the advantage of being supplied with food in the present, on the cheapest terms, is so great that it is worth while to run any risks in order to obtain it. But at least it is desirable that we should scrutinise this boon closely, and see that it confers a real benefit. It is obvious that in any given year cheap food is a benefit to the wage-earners; but it is not certain that cheap food, in and by itself, is necessarily a benefit to a community in the long run. The population of Ireland subsisted and multiplied on a very cheap food; and philanthropic effort was strained in the attempt to cope with the distress, when the potato disease first made its appearance. Cheap food is not a benefit, necessarily and invariably ; it may prove positively mischievous if it provides means for the existence of a large population in idleness, when they have no sufficient opportunities of working, or of bettering themselves. In any community where there is cheap food, early marriages are possible and a large population can be maintained at a low standard of comfort; but unless there are opportunities of employment, and a willingness to accept employment, the large population is not likely to be kept at a high level of physical condition or moral character. The Elizabethan and the Revolution policy took account not only of the food supply, but also of the opportunities and terms of employment. It is only in modern times that cheap food has been regarded as an essential of welfare that ought to be secured, for its own sake, and without any consideration of the opportunities of employment and the terms on which labour can be hired. All the factors of permanent social welfare are interconnected; it is an error to isolate any one as of supreme importance, in and by itself ; no single condition is good, absolutely and by itself, 
but only when viewed in its bearing upon national life in the long run.

(b) The wisdom of the past may be too lightly discarded; but, on the other hand, a misleading glamour may be cast over features of social life that we only see from a distance. Throughout the Middle Ages and till the eighteenth century, there were in England a number of small farmers, who cultivated the land either for their own subsistence, or in the hope of disposing their produce in neighbouring markets; generally speaking, they carried on tillage in common fields under the pressure of traditional custom and not on any scheme of their own; but they had a measure of independence as to days and hours, and were not directly under any employer. These sturdy, independent men appeal to the imagination, and there is a very general desire to reintroduce them by providing small holdings, which can be worked with a small amount of capital. The aim is not merely to introduce an economic ladder by which the man of special skill and diligence can climb into another class, ${ }^{1}$ but to reintroduce a class who should keep themselves in comfort by cultivating a small holding with a small capital.

It is to be remembered that the disappearance of the yeoman farmer was part of a general movement in the organisation of employments of every kind. In mediæval times much of the industry of the country was carried on by craftsmen who had a small amount of capital, and were not directly dependent on any employer, but made their own bargains as to materials and as to the disposal of the product. But as commercial connections developed, these small capitalists were unable to hold their own. They no longer dealt directly with the consumer, but were obliged to cater for distant markets through a middleman. For centuries the contest went on, in the cloth trade, as between the merchant middleman who bought the goods from domestic weavers, and the manufacturing middleman, who

1 See above, p. 112. 
employed workmen to weave for him, and paid them wages. The superior convenience of the position of the large employer for the organisation of business triumphed at last. The introduction of expensive machinery in the textile trades clinched the matter so far as a large part of the industry of the country is concerned. The small, independent craftsman has succumbed, and though, from an artistic point of view, the disappearance of human craftsmanship before machinery is a matter of regret, no serious effort is being made to roll back the wheels of progress and reintroduce the small manufacturer. It was the march of progress, and the facilities of catering for human wants at a diminished cost, which acted through the 'greed' of employers, and enabled them to oust the domestic weavers. Unless we go back to the old market conditions, it is not really likely that the old industrial classes could flourish ; the atmosphere of world-wide commerce proved fatal to them before. Would it be possible for them to flourish in it now? The small capitalist who survived in the eighteenth century had a bad reputation in regard to the conditions of employment, and it is to some extent the small capitalist who is the sweater of the present day.

In much the same way the small holder of bygone days farmed for subsistence chiefly, and sold his surplus produce in a local market. In the seventeenth and eighteenth centuries there was more of a national market for corn, and there were frequent opportunities of selling it over seas. Under these circumstances, it was profitable to concentrate attention on corn-growing, and to treat cattle-breeding as subsidiary; this became a less profitable use of land, and the traditional farming of the small holders ceased to be remunerative. As a class they died out, because they were unfitted to survive in the changed conditions of English agriculture; it remains to be seen whether the fall in the price of corn, and improvement in the profit on other kinds of produce, will give them a better chance. 
In his capacity as a labourer, the small holder may be stimulated to work harder than other labourers, though the plea that this will occur makes it probable that if the smaller holder is to be perpetuated, he must live a life of more continuous drudgery than the agricultural labourer does at present; the stimulus of prospective ownership would be a help to induce him to enter on the arduous struggle. The most serious difficulties the small holder would have to face would be those which presented themselves to him in his capacity as a capitalist; he would be likely to have difficulty in standing a drop of prices, or a bad season, without getting seriously into arrears.

Whether the reinstatement on a large scale of a class of small holders, raising produce for the market, is practicable remains to be seen. The difficulty of marketing can be got over in many cases where there is easy access to large centres in which there is a demand for vegetables, fruit, and eggs ; and men of exceptional ability will be able to take the best advantage of their opportunity and to rise in the world, even if the strain is great. But there is reason to fear that for some of those who enter on the occupation of a small tenancy the strain will be too great, and that, if a large area were devoted to small holdings, it might prove that the land would deteriorate or become exhausted, and that the men were at last forced to throw it up. This is not mere surmise; the description of the remaining small holdings in 1843, and of recent experiments in reintroducing them, is very instructive.

If it be true that the small capitalist has disappeared, as the practice of catering for distant markets became more common, we seem to be forced to choose between a return to the old commercial conditions-in which the old organisation of industry flourished-and the acceptance of the new commercial conditions with the organisation of industry which has proved its suitability to these conditions by coming into being under them. It is not clear that we 
can have it both ways; but the sentimentalist neglects the evidence as to the trend of change during the last three hundred years, and hopes to combine mediæval organisation of industry with modern conditions of commerce. It has yet to be proved that they can be rendered compatible, and there may be considerable loss in making the attempt.

(c) Literary persons in many ages have interested themselves in the creation of Utopias. In modern times Sir Thomas More set an example, which has been followed by Bacon, Harington, and others. There is in many quarters a feeling that if only society were reorganised in a really rational manner, which commended itself to the judgment of all human beings, they would naturally and easily conform to this social order, from its inherent attractiveness to thinking men. This was, on the whole, the doctrine of William Godwin, and it seemed to be successfully realised for a time in the communities which were organised at New Lanark, and in America, by Robert Owen. Against this opinion it is not easy to argue from experience; the one or two failures can hardly be regarded as in themselves decisive against the success of some similar attempts in the future. We cannot test the proposals by actual life, as we may the assumptions of the economist ; nor do the idealists rely on isolated instances to prove the practicability of their schemes. Some of them hope that the society might come new born into existence, and commend itself simply by its reasonableness.

The objection to such schemes does not lie against any particular feature in any one, but against the fundamental assumption which all make as to human nature. They assume that because man is rational, he is wholly reasonable; whereas the one plain fact of human nature is that man suffers from ' defect of will.' He knows what is right and good to do, but he cannot brace himself to do it all the time, constantly and steadily. He has opportunities of many kinds, and he fails to make the most of them. This 
was the fact that St. Paul deplored in his own experience, 'I cannot do the things that I would.' There was a law in his members warring against the law of his mind. This human frailty he called sin; it filled him with shame and remorse; he struggled heroically, but he could not shake it off altogether. Those who frame ideals of society, and trust that, in the conditions they devise, every one would be wise and good, are content to shut their eyes to the existence of sin, which suffices to spoil any earthly paradise.

Human weakness and frailty have been the underlying causes which have shattered many promising schemes. Idealists assume that by changing conditions you can revolutionise the characters of men, but this is not so ; the improvement of human character is a difficult process, and improved opportunities do not bring it about suddenly and at once-if, indeed, they bring it about at all. There must be that which works on the man within, as well as that which improves conditions without, if there is to be a real regeneration of society; and life develops from within. It is possible to improve conditions, and provide opportunities by external activity; but the kindling of new ideals, and encouraging of men to live up to them, is another matter. We have so far tried to survey the field in which the State can work by guiding and organising human activities, and we must now turn to consider in what way human agents can be rendered better men. Once again the appeal must be to experience; and we claim that Christian experience shows the most effective means for taking men out of themselves and inspiring them with a new sense of social duty. 


\section{PART III \\ PERSONAL DUTY}

\section{CHAPTER I \\ CHRISTIAN CHARACTER}

1. Self-dedication

(a) IN considering social and political forces, we have been concerned with factors which leave their mark upon and mould individual lives by pressure from without. A man's whole personal life must be extraordinarily influenced by its environment, not merely by the physical forces surrounding him, but also by the ideas, and conventions, and institutions of those among whom he is born; the opportunities left to him and the plans made for him by others help to determine his career and affect his character. For the most part, the moulding influence of society on the individual is exercised by pressure of various kinds; but it is not so complete and far-reaching as to render every individual completely adapted to his place in society, and satisfied to accept it cheerfully. In civilised society, the external rewards of status and of fortune, which appear to be within the reach of any individual, may rouse his ambition and stimulate his activity, without completely satisfying him ; there is likely to be some friction between society and the individuals who compose it; and it has not been possible to secure a complete harmony of private interests with those of society, ${ }^{1}$ or to secure complete

1 See above, p. 53. 
compliance on the part of individuals with rational aims and aspirations for the whole. ${ }^{1}$ The readjustment of social conditions can never suffice to give such personal contentment as to remove all causes of irritation and bitterness; under any circumstances it will still be necessary to try to foster a sense of personal duty, so that personal initiative may be consciously directed to the common good.

Social problems must therefore be viewed, not only from the side of society and the forces which it can bring to bear, but also from the side of individuals and the initiative which they possess. New ideas are not brought to bear upon the State directly, but through the minds and the activities of individuals to whom these ideas appeal; for men, who personally have high aims and force of character, can often do something to influence their surroundings, and modify society for the better. It is possible to lay so much stress on the impersonal power of the State as to underrate the power of personal influence and the importance of calling it forth, and making the most of it. ${ }^{2}$ The whole trend of thought, in recent times, has been so much in favour of relying on State regulation that it seems that the worship of the State may exercise a baleful influence in the modern world; it rests on a sentiment similar to that which found expression in the worship of the Emperor. There is a danger lest personal initiative should be repressed, and that the importance of personal intelligence and character, both for maintaining and for improving the conditions of human welfare, may be obscured. We do not habitually ignore the importance of individual genius in particular aspects of the progress of civilisation; the personal influence of great artists, who have founded schools, of great writers, great thinkers, and great discoverers is recognised on every side as epochmaking in particular departments of culture, and important

1 See above, p. 174.

2 See above, p. 150. 
steps in social and political progress in this country can also be associated with particular names. ${ }^{1}$

(b) The course of social affairs can only run with perfect smoothness when every man is trying to do his best, and the best in a man is only called forth by that which he admires and therefore tries to imitate. It must touch his imagination and affect his will. Ideas, which appeal to the individual personally and rouse his enthusiasm are requisite if the social mechanism is to work without friction ; they are essential if the social life of the community is to become fuller and more vigorous.

Enthusiasms are of many kinds ; for that which attracts and awakes a response in one man may leave another, who has a different temperament or less delicate powers of sense perception, wholly unmoved. Beauty exists in many forms and does not appeal to all natures alike; some are inspirèd by beauty of sound, some by beauty of form, or of colour, in a picture, some by the delicacy of the language in a poem, and some by artistic conveyancing. But the love of beauty in one or other of these forms may take hold of a man so as to make him feel that it is the one thing worth living for, and that nothing else really counts in comparison with the opportunities of enjoying it, and of striving to create it. To the man of artistic temperament, the pressure of external circumstances may often seem to be an intolerable slavery, and he will feel that calculations of prospective gain are sordid and mean. By such natures the aims and ambitions which are dominant forces in ordinary men can be willingly and lightly sacrificed. All enthusiasms have this feature

1 Edward I. had much to do with the organising of representative government, and with the regulating of the conditions of industrial and agricultural life through the Middle Ages. Lord Burleigh built an edifice of national economic policy, and the era of the Revolution saw a new departure in the organisation of credit, through the carrying out of the ideas of William Patterson and the founding of the Bank of England. Personal influence has been epoch-making in the course of social and economic progress; and it is also of enormous importance among the humbler ranks of society and at times when there has been no striking change. 
in cornmon, that they rouse a spirit which takes a man out of himself and renders him willing to make sacrifices; the enthusiast will readily give up, for the sake of the cause he has at heart, all that he has, and even life itself.

The forms of enthusiasm to which ordinary men and women are most susceptible are not for what is merely physical, but for something that has a human interest as well. This appears to be the case with the sense of beauty. Admiration for natural scenery is often an acquired taste ; it seems to be largely a matter of the association of ideas ; for, through many ages, men of refined natures appear to have been curiously insensitive to its charm. But the beauty of a human face appeals more strongly and more widely ; those who are, like the miller, entirely indifferent to the beauty of such a woman as Princess Ozra, are commonly regarded as exceptionally dull and gross. The delicacy of a human voice, and the body of a chorus of voices, awaken a response in the minds of many who are quite unmoved by orchestral and chamber music; beauty appeals most strongly, and is appreciated most widely, when it is expressed in and through a living personality. The most widespread of human enthusiasms is rendered more attractive and intense when it takes a personal character.

Patriotism has also the power of rousing high enthusiasm and calling forth great sacrifice, though the ideal elements it contains are to a considerable extent impersonal ; it may stir men, who have few personal ties with their country, to fight and die for it. The love of country may be partly made up of a delight in its familiar physical features, its colouring, its air, and the habits of life, and partly from the romance of its history ; it is a striking example of the hold which ideas may take on certain minds, while there are others who appear to be destitute of any love for their country or pride in it. But of patriotism, too, it may be said that it is most inspiring and effective when it can be personified; by being associated with the figure of some 
hero who felt the keenest love for his country and devoted himself to her service, his life calls forth admiration and his example is infectious and incites others to imitate him.

(c) One life stands out unique and alone in the history of the world, both because of the special enthusiasm by which it was inspired, and the self-sacrifice in which that devotion found expression. Of our Lord Jesus Christ, it was true that no merely earthly aim distracted Him from the constant and single-hearted desire to do the will of God. His supreme aim for His own life was that it should be in perfect conformity to the will of God ; His one ambition was to give effect to that will in His words and deeds. His life was not inspired by a mere enthusiasm for humanity, but by a love of the Eternal Father, and a desire that the glory of that Father should be fully manifested through the perfecting of His children upon earth. The life that was thus inspired has been the light of men; it has revealed to the world the express image of God ; countless men and women, who have looked at that perfect life, and that utter self-sacrifice, have echoed the soldier's conviction, 'Truly this was the Son of God.' And the example of His devotion to God has not only called forth admiration, it has wakened the desire to have a part in it. ' $I$, if I be lifted up from the earth, will draw all men unto Me.' The thought of the goodness of God, as manifested in the person of our Lord Jesus Christ, has appealed to generations of Christian men, as the supreme aim of life, and as something to which the whole life may be gladly consecrated.

In the person of our Lord Jesus, the meaning of the service of God, and the enthusiasm for that service, were alike set forth among men. Devotion to the will of God was exhibited by Him, in the manner in which it can appeal most widely to men of all races and ages, and may influence them most strongly. Since the Incarnation, human enthusiasm for realising the Divine Will takes the form of loyalty and devotion to the Divine Christ, Who so- 
journed among men, Who ever lives to make intercession, and Who strengthens and encourages by the gift of His abiding Spirit. The work of the Church $\mathrm{He}$ founded is to apply to individual members of countless succeeding generations the vitalising power of His life; to foster in every member of His Church something of the devotion to God which dwelt in Him. The prayer He taught us to pray is instinct with devotion to the Heavenly Father, that His name may be hallowed, that His kingdom may come and $\mathrm{His}$ will be done.

(d) Enthusiasm of any kind is an extraordinary force in human affairs, but the life of Christ has awakened a wider response, among men personally and individually, than any force the world has known. The fact that Christian enthusiasm appeals to men of all races and all degrees of civilisation is clear from the progress which Christianity has made in spreading throughout the world. The Gospel is being preached among all peoples; and despite all defects in the mode of presentation, it finds an everincreasing response. The intensity of the enthusiasm it arouses may be measured by the sacrifices which have been gladly made for the sake of Christ. In the noble army of martyrs there has been a continued testimony to the depth. of this devotion.

Christian enthusiasm has also a very special quality of its own, since it does not spring from earth, or anything earthly, but is rooted in the love of the God Who has made Himself known to man; it is spiritual, and hence it is allembracing; it does not deal with one aspect of human nature only, but touches all human aspirations and concerns -not only the inner life but the outer world as well. Men of artistic temperaments are inclined to lead their own lives apart, and to hold aloof from surroundings that grate on their sensibilities; the streets where men live are full of ugly sights and harsh sounds. The ascetic of any creed may seek to crush the passions and desires after earthly 
things which perturb and harass the spirit, and interfere with the attainment of complete philosophic calm. But the Christian enthusiasm is two-sided : on the one hand, to be formed after an ideal, and, on the other hand, to take part in Divine activities. And hence Christianity has this other characteristic which distinguishes it from so many of the ideals which men have set before themselves : unlike some other aspirations, it is so completely practical. It can be brought to bear upon all human conditions and interests ; it does not lie apart from any of them; alone among the great enthusiasms that have moved the world, it can be habitually harnessed to the humble and routine tasks of daily life.

Alike in the life of the meanest slave, and in the discharge of the responsibilities of the autocrat or the millionaire, there is some room for the play of individual character. However highly organised society may be, either on the lines of slave-labour, of independent capitalists, or of giant industry, there must be some free play for the individual as to the manner and spirit in which his time is employed; and thus the Christian enthusiasm may be brought to bear in any system of society or under any political conditions by its influence on the individual ; it is of universal applicability in mundane conditions ; fust because it is thus universal it is capable of extension to all races and of being maintained for all time. Herein the greatness of spiritual power appears, in that it operates apart from all the special conditions of time and place; it is capable of universal extension, and it exhibits undying power. No mere humanitarian sentiment of brotherhood ${ }^{1}$ can compare with devotion to the Living Christ, either in the range or the effectiveness of the appeal. It is the claim of Christ's gospel that it offers the most effective means the world has ever seen for influencing men personally and individually, by holding up an ideal for all to admire and to desire to

${ }^{1}$ See above, p. 153. 
imitate, an ideal which is so high that none can attain to it perfectly, and that yet lies so near that all may aim at it in every action of life.

\section{Personal Service}

(a) The gospel of the grace of God may exercise a double influence on any life that is deliberately yielded to its influence : on the one hand it gives a new motive for doing duties of every kind, and on the other it throws fresh light on certain kinds of conduct. So far as duties, which are recognised in ordinary society and enforced by the law of the land, are concerned, Christianity supplies an additional motive for doing what is right, not merely from the fear of man, but out of a desire to please God. ${ }^{1}$ But there are many duties in regard to which human institutions and maxims speak with an uncertain sound; and the nature of the duty that ought to be done becomes more clear when it is viewed from the Christian standpoint.

Ordinary social morality is concerned with external acts ; it cannot pretend to give positive guidance as to what ought to be done on every occasion, and so it lays down rules as to what should not be done. There are laws which prohibit certain crimes, and these are enforced under penalties by the magistrate; breaches of good manners, and conduct that is dishonourable or ungentlemanly, are forbidden under the sanction of a social ban. But as long as conduct is correct, society will give its approval ; it does not pretend to pry into the inner life, or gauge the personal character. Christian influence begins with that which social morality is forced to leave on one side ; the gospel aims at influencing the inner life and character ; and it endeavours to accomplish its aim, not by mere prohibition, but by holding up an ideal. Christianity sets forth positively what is good and pure and noble, in the hope that it will win admiration and

1 See above, p. 43. 
call forth effort. Social morality is prohibitory; it seeks to impress and mould the individual from without, while the gospel is inspiring, and by planting and fostering what is good within the man, goes to the root of the matter, in the confidence that a better life will develop from within. The cultivation of good serves as a touchstone to detect evil, and it may be the most effective method of disarming the attractions of evil; but such effects are incidental, rather than the conscious aim in the building up of Christian character. The maxim to cleave to that which is good is paramount in Christian morality : it is by holding up that which is good, so that men may feel its attraction, that evil may be discarded and its influence be outgrown; and this whole method of procedure is the very reverse of the course pursued by ordinary social morality. Christianity goes far deeper than any social morality, and brings more effective influence to bear upon the personal life.

(b) The insufficiency of ordinary social morality is conspicuous in regard to the restraint of animal passions : external correctness, and decency of behaviour can be enforced; but the springs of evil, in the imagination and the desires, cannot be reached, and occasional irregularities in men's lives are commonly treated as excusable. Here again, Christian influence begins with the inner life, and is brought to bear upon secret conduct; it holds up positive ideals, which may take such possession of a man's nature as to prove an expulsive force and drive out what is gross and impure.

The life of perpetual virginity, - of complete chastity,-is held up as an ideal both in Scripture and in the Church; it is commended as the most complete self-discipline, and as the condition of life which may be most free from anxieties and distractions. This ideal has had a strong fascination for many men and women; and, as realised in the life of the Benedictines, it played a great part in the conversion of the barbarians who had overrun the Roman Empire. 
Many modern men cherish a different conception of duty in this matter, as they feel that the power of perpetuating the race is the greatest privilege and responsibility that falls to the lot of man. It is of supreme importance that the men and women of the coming generation should be sound in body and mind, and fitted to enjoy and maintain the great heritage of civilisation on which they will enter. To carry on the life of a.worthy stock, and of a great nation, is a duty and responsibility which selfish natures are ready to shirk. In the recognition of paternity and maternity, as a privilege involving much anxiety and care, the whole conception of sexual relations is elevated, and redeemed from everything that is merely gross and selfish. The conception of Christian marriage includes at once a field for self-discipline and self-sacrifice, and the exercise of authoritative care and discipline in a household; it is a high vocation, and not to be undertaken lightly. Men who aim at entering this state, who have a high conception of the responsibilities of paternity, and desire to fit themselves in mind and in body for the discharge of its duties, have set an ideal before them which is an incentive to purity of thought, and a safeguard against irregularity of life. ${ }^{1}$

The maintenance of a high aim in this matter, and the formation of a character influenced by either of these ideals, is a personal matter; the conscious effort of the Christian is to carry out a personal duty, and to bring every thought and act under the obcdience of Christ ; but none the less there is, indirectly, a very real influence on other lives as well. Personal example in refraining from contamination, even by the indulgence of curiosity, is a far more effective protest against the worst of social evils, than any attempt to expose the shame and horror of vice can ever be. The course of personal conduct, which Christianity commends, has also a bearing on the most far-reaching of all economic difficulties; the indulgence of

1 H. Wegener, Wir jungen Männer, p. 183. 
animal passion is the cause of the constant pressure of population on the means of subsistence, and of all the poverty and misery to which it gives rise. The strongest of all preventive checks will be found in the high ideal which Christianity maintains of marriage as a vocation, and of continence as a duty.

(c) Other personal duties take an entirely new character when they are viewed from the Christian standpoint; this is especially the case in regard to diligence in business. According to the common sense of mankind, the ordinary routine of work is a drudgery to which most of us are driven by necessity, and this view of the case gets a certain sanction from Old Testament theology, in which the obligation to labour is represented as imposed on mankind as part of the penalty of the Fall. Diligence may also be enjoined as a counsel of prudence, and the Books of Proverbs and of Ecclesiastes are full of admonitions to work from this point of view. But the teaching of Christ raises it all to a higher level ; He has taught us to think of God as the supreme worker, with a purpose in view which all created things were intended, to subserve; Christ Himself, in His human nature, realised, as no man had ever done before, that in all His activities He was called to be a fellow-worker with God. 'My Father worketh hitherto, and I work' ; all His teaching and all His healing was to Him a conscious carrying out of God's work in the world. The same idea comes out in St. Paul's writings ; all his activities, whether he was labouring as a tent-maker, or disputing with the Jews, or preaching to the Greeks, or writing to his converts, were undertaken with the desire of being a fellow-labourer with God, and in the hope that God's blessing would rest upon his labours. In this way we get a clue to the very meaning of work in the Christian view of life ; work is the active effort to give effect to the will of God. ${ }^{1}$ The whole is taken out of the range of personal interests and selfish gain, and 
raised to a different level, when our activities are thought of as devoted to the carrying out of God's purpose. All work has this character, whatever direction activity may take. The work of God in creation prepared the earth to be the dwelling-place of man, and all the energy and enterprise which are devoted to developing material resources, and providing for the increased comfort of growing populations, may be consciously undertaken with the thought of carrying out God's purpose for mankind more fully. We may also recognise that in the course of the world's history there has been an education of mankind in the preparation for the coming of our Lord, and in the institution for diffusing and maintaining the Faith once delivered to the saints ; and that all that is now done for the improvement of human powers in mind, or character, or will, is a carrying on of this side of the Divine working in the world. There is no task, however humble or however high, that may not be thought of religiously, as a vocation assigned to us by God, and each man is called to co-operate with God by diligence in his vocation.

From this Christian standpoint, we can see the true dignity of work, and may recognise that it is a duty incumbent upon all. If work were really a penalty, or merely a drudgery, there could be no discredit in trying to escape it. In the ancient world, as well as in Judaism, work was regarded as a necessary evil which was contrasted with a life of leisure-work as something to be done at the will of another, and leisure as the opportunity of pleasing oneself. But from the Christian standpoint, this contrast cannot be sharply drawn; all time is to be spent in accordance with God's will ; none is to be spent by the Lord's servant in self-willed indulgence, or in disregard of his Master's will. Some men have tasks assigned them at which they must work long hours to maintain their independence, while others are free to choose the direction of their energies, and to undertake duties that are unremunerated; but the 
Christian duty of diligence is the same in all these cases. Since there is a high dignity in work, the refusal to work on any excuse, or the deliberate claim to live in idleness, is a $\sin$.

The deliberate effort to consecrate the toil of every day as it comes, by regarding it as something done for God, has been recognised as a Christian duty in all ages, 'Not slothful in business, fervent in spirit, serving the Lord'; 'Not with eye-service as men-pleasers, but as the servants of Christ doing the will of God from the heart' ; and again, 'Whether ye eat or drink, or whatsoever ye do, do all to the glory of God.' This is the character which the Christian is to cultivate in respect of the use of his time; it is the condemnation of all self-will and self-pleasing, whether that is shown in doing work badly, or in mere idleness.

(d) The strength of the influence which Christian devotion can bring into play is exhibited in its power of restraining passion; but in connection with this thought of personal service of God, we may see how far-reaching this influence is, and in how many different directions the principle may operate. Just because it is at work within, this devotion not only inspires to activity, but may colour and affect all the relationships into which we are brought through these activities.

The bearing of employers towards employed, and of men to masters, would be entirely altered, if the contract between them should cease to be thought of as merely their private affair, which begins and ends with themselves and their class. ${ }^{1}$ Christianity insists that no man liveth to himself. The employer is not wholly independent; since he is God's servant, and he has no right to be either arrogant or arbitrary in the part he plays in that service. His dependents of every kind are to be thought of, however menial their tasks may be, as fellow-servants in one household. The employer is to treat the fellow-servants as his 
Master would wish ; from this new point of view he will not overlook any lack of diligence and thoroughness in work; he is to be a strict foreman, and not to connive at the carelessness of other servants. But since, through business relations, he is brought into touch with them, he is called on to think, not merely of the time and quality of service, but of the conditions of their lives, and the possibility of ameliorating them. His Master cares, not merely for the quantity and quality of the out-put, but for the loyalty of His servants of every rank. The employer is called upon to give his thought and care to ameliorate the conditions and raise the character of the lives of those who are dependent on him-not out of any mere humanitarian sentiment of brotherhood, but because this is the duty enjoined by his Master on all who administer any part of His household. The recognition by the men of the fact that their employer is, after all, a fellow-servant, need not make for disrespect, but for respect of a different kind ; the employer has been set over them ; they are not called upon to criticise or to interfere in the task that has been committed to another man. In so far as this religious view makes itself felt, the men will be less ready to meddle in the control of the business, or to try to run it on their own lines and in what they believe to be their interests. After all, neither the interest of the employer, as he sees it, nor the interest of the men, as they see it, is paramount, when all alike are servants.

The Christian conception of work as a form of personal service is instructive in other ways, as it sets many questions as to the intensity of work and the advantages of leisure in a new aspect. Where a man views his work as his mere private affair, and pursues it for the sake of personal gain, the virtue of diligence may degenerate till it becomes a self-imposed tyranny; ' it is but lost labour that they rise up early and so late take rest, and eat the bread of carefulness.' The principle which condemns over-eagerness about the reward of work, may also correct the undue 
hankering after amusement. There may be a misuse of leisure, as well as a too great intensity of application to work; where free time is spent in such a way that a man is less fitted, in mind or body, for devoting himself to the day's task, there has been unwise self-indulgence. Resting and recreation alike serve their purpose by rendering a man better fit for the active exercise of his faculties in his vocation.

Here once again we find that the direct aim of Christian teaching is to form Christian character, so that the whole life of the man shall be led in increasing accord with Christian ideals. This teaching can give a contentment in uncongenial employments, and can inspire to diligence in business which has to be done without hope of reward. But while its primary influence is on personal feeling and character, it has indirect bearings on social life as well. It may help us to distinguish, not only for ourselves but for others, what is right with regard to intensity of application, and wise in regard to various forms of recreation. Its effect may be felt in society at large, in so far as it conduces to diligence that is not dependent either on compulsion from without, or on mere self-seeking. By aiming consciously at the service of God, it comes indirectly to accomplish much for the good of man.

\section{The Responsibility of Trusteeship}

(a) Only a very slight extension is needed to make the Christian conception of service, which has been delineated in regard to human activities, applicable also to human possessions. It has been pointed out above, that the rights of private property are exclusive as against private persons and as against the public, ${ }^{1}$ but no human being can claim to have the exclusive ownership and right to use any created thing as against God. Human life is short at the

1 See above, p. 86. 
best; man enters on life naked, and he can take nothing with him when he dies ; but the earth remains, the seasons come and go, and the work of the world continues. There is one Purpose and Mind abiding and controlling still; 'The earth is the Lord's and the fulness thereof.' $\mathrm{He}$ is the creator and governor of all ; the rights and privileges and possessions and immunities of human proprietors sink into utter insignificance, when we realise the truth that all we claim to use is not really ours, except as the power to use it is given by Him Who is the creator of all things and the Father of all men. From this point of view, it is clear that all human proprietorship is of the nature of stewardship-that man is in the position of a trustee responsible for the administration of the goods in his hands, to Him who conferred this trust. Man can never be justified in claiming to exercise his ownership in a manner that is irresponsible or arbitrary. No man can ever be justified in asserting a right to do as he likes with his own; it is not his either to waste or to destroy. Man has nothing that he has not received; he is not an absolute owner, who might insist on a right to carry out his own whims capriciously, but a responsible servant to whom the use and control of certain things has been committed by his Master.

(b) This Christian sense of responsibility is an incentive to lead a man to use the resources under his control in the best way. He is encouraged not merely to avoid the careless and reckless destruction which has so often characterised human conduct, but to employ his possessions in a manner which is in accordance with his Master's will, so far as he can understand it. In this decision, the conception given in Scripture of the purpose of creation must be a guiding principle. The maintaining and improving the life of the community, and the fitting of property for those uses which best subserve the requirements of the community, ${ }^{1}$ may be attempted, not merely

1 See above, p. 139. 
for the sake of personal gain, but from a sense of religious duty. The same thought may be brought to bear in regard to the choice of the direction in which wealth is employed, and the investment of capital. There are directions in which men ought to feel that it is wrong to use their wealth ; as, for example, in catering for demoralising tastes in opium dens, or places of low amusement, however much sordid gain such investments of capital may bring. But, on the whole, the man of wealth may be confident that he is employing his wealth to good purpose, if it is so used as to afford employment and to give to other men the opportunity of leading industrious and self-respecting lives. ${ }^{1}$ In the present régime of giant industry and competition, the extent to which any man is free to modify the terms and conditions of employment may be very narrow, and the best results are secured by prudent action on the part of the State in prohibiting what is infurious to the standard of life. ${ }^{2}$ It is the duty of the proprietor, as a citizen, to help by his experience to do this wisely; but where there is no outside pressure, and in so far as he is free to act and has a part in the management of a business, he is responsible for the conditions of life and the welfare of those who are his dependants.

The duty of considerateness, which comes upon every employer, comes also in degree on every shareholder in a great railway or industrial company. Those who lend money to Governments, or are debenture holders in public companies, may be satisfied if the purposes for which the loan is made commend themselves as sound; but the ordinary or preference shareholder is both morally and legally a partner; the man who is entirely ignorant of the conditions of a business from which he derives an income cannot attempt to discharge this responsibility; he neither knows how far anything is wrong, nor in what way it may be possible to put things right. The re1 see above, p. 94.

2 See above, p. 90. 
sponsibility of the individual shareholder is small, but it cannot be right to shirk it altogether, and it is a duty for every partner to try to discharge it to the best of his power.

(c) The fact that some men have very large possessions while others are poor, and the inequalities of life, are hard to justify, when property is regarded as a private thing which a man may use capriciously; but they cease to be a serious evil in so far as the wealthy realise that great property entails great responsibilities, and that the rights which they claim as against other men imply also duties which they are bound in the sight of God to discharge towards other men. The possessions with which a man has been entrusted help to mark out the career on which he can enter, ${ }^{1}$ they help to define his vocation in life, and thus great possessions are a call to special service. The man who has large property has the opportunity of undertaking work that is unremunerated; and much of the work that is best worth doing in the world, in science and literature as well as in public life, is unremunerated. Similarly, the man who has a large amount of 'personal capital'2 may aspire to direct his energies to the higher walks of professional and administrative life from which other men are excluded; but the obligation 'to do what the hand finds to do heartily and as unto the Lord' remains the same in any and every walk of life. The author or the teacher may scamp his work as really as the much-abused plumber, though his negligences may not be so easily detected; but the duty of conscientious work, even if it is inadequately paid, or when it is altogether unpaid, is always binding. At a time when the position and rights of the owners of property are being called in question, and when there is so much eagerness to level down, the continuance of their privileges must largely depend on the extent to which the owners of large possessions recognise their responsibilities, and regard

1 See above, p. 109.

1 See above, p. 111. 
their wealth not merely as an opportunity for enjoyment, but as a call to service.

(d) When the responsibilities of possession are looked at in their religious aspect, the current phrases in regard to the sacredness of property come to have a new meaning. Property is sacred, in so far as the facts, that it has been conferred by God and ought to be used for His will, are recognised. ${ }^{1}$ Hence misuse of property springs from the failure to recognise this responsibility; the root goes very deep, and the mischief spreads in many directions, so that utilitarian considerations as to apparent and obvious waste do not bring it to light. The essential evil in gambling lies in the fact that it is avowedly and deliberately a careless and reckless use of money for mere passing excitement, and that it is the bold denial of any responsibility on the part of the owner for what he does with what he calls his own. The evil of gambling has spread so very rapidly during the last generation among the working classes, and it has come to affect a great deal of commercial business so injuriously, that it raises many problems which it is important to consider from a Christian point of view.

We need not forget that there may be many cases which are exceptional, and where gambling is not necessarily wrong. It may serve the purpose of recreation; the counter-irritation of losing sixpence a hundred at bridge in the evening may be a wholesome distraction from grave anxieties that have pressed upon a man all day, and thus serve as a preventive of insomnia. If a man does not venture the loss of more money than he can rightly afford for recreation, he does not do wrong, provided the man he plays with is in a similar position. Gambling can be justified under such conditions; but looked at on the whole, the practice is more than questionable, because of the likelihood of inducing those who cannot afford it to indulge in it, and because it gratifies a desire to gain apart

1 See above, p. 85. 
from service rendered. When thus indulged, gambling is wrong ; it is irreligious, because it implies the claim to be irresponsible and to throw money about; it is unsocial, because such gain as accrues is obtained at the expense of others and without the rendering of any service to the community; hence it lies under a double condemnation.

A complaint is commonly made that business in the present day is mere gambling, and that there is no difference between gambling at Monte Carlo and gambling on the Stock Exchange. It is true that there are risks and uncertainties in business; wherever there are risks or uncertainties it is possible to gamble on the chances, and many sorts of business offer opportunities for gambling. But to men of business who are trying to do business, the gambling element is a difficulty and a nuisance; business of every kind is organised in order to cater for the wants of the public. Good business is done by the man who caters successfully; he tries to foresee the uncertainties of business, so as to guard against them, and to reduce their disturbing influence to a minimum ; it is the effort of the merchant and manufacturer to eliminate risk and uncertainty as far as may be, to provide against the possibilities of loss, and to enter on undertakings where a prospect of gain, perhaps more or perhaps less, may be counted upon. Constant thought and attention are needed to minimise risks and to carry on business. Those who enter on business as if it were a game of chance, are doing no service to the public ; lucky chances may come to them at times, but men who hope to live by lucky chances, and not by honest effort, are merely preying upon the energy and enterprise of others. ${ }^{1}$ The legitimate business of the Stock Exchange is of service to the community, as it enables the available capital of the public to be directed into investments in which it gives income to the owners and employment to the labourer. It provides the machinery 
without which investors would have great difficulty in finding how to use their capital; and many beneficial enterprises could hardly be undertaken if some such organisation did not exist. That the facilities which it offers may be misused is true enough; it is likely to be true so long as there are knaves and fools in the world ; but to stigmatise all business in which uncertainties enter, as if it were mere gambling, is to overlook fundamental distinctions. Business is not a lottery in which the ignorant and the skilled have an equal chance of success ; it is something that has to be pursued with patience and diligence, and it reaps its reward because of the service which it renders to the public.

Most mischievous as gambling is, there is great difficulty in framing and enforcing any rules and regulations which shall serve to check the practice, either as it is carried on in connection with sport, or as it affects business. The legislature and the police appear to be almost powerless in the face of this growing evil: the best hope of dealing with it lies, not in attempting to put down the practice, but in endeavours to exorcise the spirit of gambling. This can only be done by cultivating a sense of the responsibilities of property, and the case is of interest as it illustrates the truth that Christian influence can reach and touch evils that elude all other methods of dealing with them $;^{1}$ what cannot be eradicated by direct methods of attack may be outgrown.

Christian devotion, as a spiritual force, has the promise of the life that is to come ; but to those who are seeking to realise the will of God, all other things are added. It is a living power, which operates indirectly on society, through the individual hearts and minds to which it makes its appeal by the attractiveness of perfect goodness incarnate in a human form. It is strong enough to master passion. It is far-reaching and can permeate all human relationships,

1 See above, pp. 18, 175. 
so as to redeem them from selfishness and self-will. It can go to the root of evils which superficial remedies fail to touch in any way. It can serve more effectively than anything else to rouse the sense of personal duty, and to enable men to make the most, for themselves and for others, of the opportunities offered in a well-ordered society. 


\section{CHAPTER II}

\section{SECULARISED CHRISTIANITY}

\section{Avowedly Christian Socialism}

(a) From apostolic times to the present day there has been clear and consistent teaching as to the manner in which Christian belief ought to affect men's lives. St. Paul urged on his converts that they should dedicate themselves ' a living sacrifice to God, and be transformed by the renewing of the mind.' This change of personal character was to find expression in all the duties of life, and thus to affect society. But some Christians, who still recognise that this principle is sound, seem now to be disheartened by the slowness with which it operates; they are anxious that it should be supplemented by something more direct. The philanthropy of the present day sees that social evils exist on a large scale, and insists that they must be dealt with in a wholesale way. It is thought to be altogether inadequate to be content with seeking for a lost sheep here and another there, while there is need to elevate and improve the masses of mankind. It is plausible, too, to say that Christ's teaching was social and not merely personal, and that, proclaiming the kingdom of God, He was assuming the reconstruction of society as part of His mission. ${ }^{1}$ The very fact that $\mathrm{He}$ cared for and healed men's bodies seems to show that He thought of the conditions and externals of life, as well as of the heart and of the soul. ${ }^{2}$ It is said that, if we are to interpret the gospel message in all its

1 See below, p. 218.

2 See below, p. 220. 
fulness, we must try to supplement its work on the character, individually and personally, by formulating and carrying through schemes for bringing a direct influence to bear, in the name of Christ, upon the disorders of existing society. Those who are keen to apply Christian principles directly to social institutions, and to the regulation of social forces, are conscious that they are making a new departure : while apologising for the remissness of other generations of Christian men, they claim that Christianity is now setting herself to enlarge the sphere of her action, so as not merely to work for the salvation of souls, but also to take a lead in the cause of social reform.

This enlarged view of the scope of the teaching of Christ commends itself to philanthropists, who resent the exclusiveness which characterises much Christian effort. The Church, they say, no longer presents a united front to the world; the differences of opinion among professing Christians, on points of doctrine and ecclesiastical organisation, render it impossible for all Christians to work heartily and loyally together in matters of doctrine, and worship, and the fostering of personal religion. But they urge that the pettiness and jealousies, which have been such a hindrance to the cause of religion, need not interfere to check the progress of Christian philanthropy. In practical schemes for the benefit of the masses, it would seem that all who have the welfare of their fellow-creatures at heart can ' Join hands and work,' whatever may be their opinions on points of faith, or their professions in regard to worship. 'He that is not against us is with us' is quoted by those who call themselves Christian Socialists, as indicating a duty to go forward with works of philanthropy and social amelioration in the name of Christ, and to welcome the assistance of all who are willing to range themselves under that banner.

(b) Now, undoubtedly, there are many philanthropic works in which a Christian man may feel called upon to engage, and in regard to which religious questions need not be 
raised at all. Just because Christianity is a spiritual power, it can be brought to bear in any and every direction. ${ }^{1}$ It is the duty of the Christian citizen to take part with others of any creed or of none, in using the power of the State to put down what is injurious in the action of competition $;^{2}$ he ought, indeed, under the influence of the Christian motive, to be more eager than other citizens to discharge any secular duty and to carry on any measures that make for the amelioration of the conditions in which human life is passed. The same thing is true of much voluntary effort and voluntary association for the promotion of welfare ; the work of hospitals and of district nurses, of societies for the organising of charitable relief, and for the protection of children, may all enlist the active sympathy and personal help of good men of any creed. But just because these efforts have a humanitarian character, and may count among their enthusiastic supporters Jews, Turks, and Infidels as well as Christians, they are rightly characterised as non-Christian. There is nothing about such philanthropy that is specifically and peculiarly Christian. It is the duty of a Christian man to be a good neighbour and a good citizen; a Christian ought to set himself to do the duties of citizenship and of neighbourliness well ; but such duties are not incumbent on Christian men only or exclusively, and may be well done by men who would disclaim any Christian belief; kindliness may be dictated by humanitarian considerations. Christianity has no monopoly of the cardinal virtues; there have been many upright, just, courageous, and temperate men who made no profession of Christianity; and in much the same way it is true that while human kindliness, and efforts for the promotion of social welfare, are inspired by the love of Christ and may be undertaken for His sake, they are not in themselves exclusively and specifically Christian.

(c) At this point a question arises which is not merely a

1 See above, p. 19.

2 See above, p. 105. 
question of names, though it must be raised about the right use of a term. Ought any scheme or conduct, which is not essentially Christian, to be called Christian at all ? Can there be 'practical Christianity' which is not based on conscious devotion to Christ? Does not this phrase involve a misleading use of our Master's name? Few things are more striking in our Lord's earthly ministry than His insistence on single-hearted devotion: again and again He applied the test whether men were willing to forsake all and follow Him; He speaks strongly about the impossibility of serving two masters. The conditions of earthly existence, the needs of food and shelter, are pressing; in the minds of many socialists they are of supreme importance, and nothing else counts. Christianity ceases to be Christian if it puts the material prosperity of the masses in the forefront, as the thing that is to be aimed at first and before all else, and only claims that religion is not to be overlooked as one of many means for realising this secular aim. This is Mammon worship; even if it is humanitarian and philanthropic, still it is Mammon worship, and an apostasy from Christ, who sets before us a spiritual aim as the supreme object in earthly life. And in all proposals to supplement the ministering of the means of grace for the salvation of souls, by direct efforts for the ameliorating of conditions, as another form of specifically Christian work, there is a danger of setting up a secondary object alongside of the supreme object of Christian devotion, and thus of yielding a divided allegiance. There is at least a possible danger of giving undue prominence to secular and mundane objects, and of allowing the spiritual to be relegated to a subordinate place, instead of treating it as the essential remedy for the evils of our day. As Maurice insisted, ' the circumstances of our time show how certain it is that society in the most civilised lands will perish through the frauds of rich men as well as poor men-of the most refined and the most outwardly religious-if there is not 
some power which can create a habit of honesty, which can resist the secret temptations to flagrant dishonesty in men whom neither the terrors of law nor of public opinion can hinder from bringing disgrace on themselves and ruin on their fellow-citizens. Such discoveries give us stronger reasons for asking whether the news of such a Power which came to men centuries ago must be discarded as false, whether they may not be accepted in a more complete sense than they have ever been? There are other facts which the sight of the streets in every civilised capital bring home to us, which are brought much more vividly home to those earnest men who have penetrated into the dwellings within these streets. Much, very much has been done-much more might be done-for the improvement of those streets and dwellings by mechanical contrivances, by medical knowledge, by wise legislation. But there are habits in men and women which may set at nought the effects of all mechanical contrivances, of all medical knowledge, of the wisest legislation. They cannot be reformed by any of these; till they are reformed they will produce ever more crimes, ever fresh misery. Who can work this reformation? Threats of punishment cannot, promises of reward cannot. Is there not some demand for the old faith in a Spirit to regenerate social life as well as individual life, to overcome the sources of death, ultimately to raise men out of death itself ?'1 The philanthropist is not a Christian philanthropist unless his hopes and efforts for his fellowmen are inspired by confidence in the reality of spiritual power, as working in the world here and now.

\section{Mundane Theocracies}

(a) It is difficult to see the grounds for the common complaint that the Church has been too exclusively occupied in that which is spiritual and has not given sufficient 
attention to secular life. It would be more true to say that there has always been a temptation to look too much at the constitution of society and the possibility of modifying it in a Christian sense, and to neglect the primary claims of the spiritual life. This temptation has taken different forms in different ages, according to the constitution and aims of civil society for the time being. In a democratic age, it takes a shape which is different from that which it assumed in connection with Imperial institutions or personal monarchies ; but there is always a temptation for Christianity to adapt itself to the spirit of the age, and conform to the conditions of society, to such an extent that it loses the power of transforming them into closer accordance with its own ideals. The dream of organising a divine theocracy, in which effect should be given to the Divine Will among the affairs of men by means of civil power, has often been pursued in such a manner as to distract attention from the supreme importance of spiritual things, and to bring discredit on the Christian religion.

This attempt to bring Christianity directly to bear on society is very natural, since Christianity has sprung out of Judaism, and Judaism claimed to be, in its place and time, a divinely instituted mundane theocracy. The kingdom of David and of Solomon was thought of as an earthly kingdom in which God's will was the supreme rule, and regulated the tenure of property, the treatment of dependants, and all other social matters. The first disciples were full of the expectation, during our Lord's ministry, that $\mathrm{He}$ had come to establish such a theocracy, but on a still more magnificent scale and exercising a world-wide influence. Throughout the early centuries of the Church the organisation of the Roman Empire served to give shape to the aspiration after establishing a great theocracy in which spiritual power should be supreme; and this found expression in the institutions of Latin Christendom. At a still later time, the Presbyterians in 
Scotland and the Puritans in New England attempted to create a social condition which should be thoroughly and entirely Christian; but the lack of success which has attended these efforts to Christianise civil and social conditions should give us warning. In each case the failure has been palpable. From the principles with which they started, of purifying society from all unchristian elements, there was much to be said for the drastic measures adopted by Inquisitors and for the severities towards Salem witches. But these things have brought discredit upon Christianity and have repelled men from it altogether. Even the less strenuous efforts of English Churchmen and Scotch Presbyterians in the seventeenth and eighteenth centuries, to enforce external compliance with Christian morality, in external courts and by external sanctions, failed to justify themselves, and left the impression in many minds in the eighteenth century that the established churches were mere departments of State.

(b) There is another way in which Christianity may be infured by being closely identified with the civil institutions of some particular place and time. Christianity is not for an age, but for all time; while economic conditions and social relationships in any country, and certainly in progressive countries, can only be for their own age; none of them can be valid for all time. To insist that any one form of social organisation is prescribed by Christianity is implicitly to deny that other forms may also be suffused with a Christian spirit. To create a form of social arrangement, and claim that it is in complete accordance with Christianity, is to identify Christianity with something that is merely passing. Just as the Classical Economists were unconsciously affected in formulating their doctrine by the circumstances of their own days, ${ }^{1}$ so Christian moralists may be tempted to mould their conception of social duty on what is requisite at one particular time; they are in danger of ignoring other

${ }^{1}$ See above, p. 166. 
duties which are equally important on the whole, but on which it seems unnecessary to lay stress at some given period, so that they temporarily drop into the background. We may see, in retrospect, how the concentration of the efforts of religious men on one sort of social evil in the seventeenth and early eighteenth century-to the neglect of other kinds of mischief-has tended to discredit Christianity itself. Unemployment and idleness were the characteristic evils of the seventeenth century both in England and Scotland; the great method for introducing a godly, sober, and righteous life into the community appeared to be that of getting the population to submit to the discipline of work. There were no half measures in the Scotch treatment of vagrants according to the Act of 1663. ${ }^{1}$ Capitalists who set up manufactories were empowered to impress any vagrants and 'employ them for their service as they see fit ' for eleven years, without wages except meat and clothing. Good subjects were recommended to take into their service poor and indigent children, who were to do any task assigned them till they had attained the age of thirty, and to be 'subject to their master's correction and chastisement in all manner of punishment (life and torture excepted).' The seventeenthcentury Puritan took a stern view of the discipline which was good for children, so that they might be kept from forming habits of idleness and drifting into evil of every kind. But, while there was a strong sense of the religious duty of insisting on hard and regular work, for the welfare, temporal and eternal, of the people themselves, there was a complete indifference to the need of laying down or enforcing any restrictions as to the employment of money. Capital was much needed in England, and still more in Scotland, for developing the resources of the country and for starting new enterprises; freedom for the formation and investment of capital seemed to the thoughtful city men of the

1 Scots Acts, 1663, c, 52, re-enacting 1579, c. 12, 1597, c. 39, and 1617, c. 10. 
seventeenth century, who were mostly in sympathy with Puritanism, the best remedy for the existing social evils. They were eager to get rid of the restrictions, imposed by the 'Pope's laws,' 1 which it was possible to bring up in ecclesiastical courts, as well as to be free from efforts made by the King's Council ${ }^{2}$ to bring home to the employing and mercantile classes their duty to the community. The agitation against the interference of the bishops in civil affairs, and the triumph of Puritanism, swept away all traces of any restriction or guidance in the employment of money. In so far as a stricter ecclesiastical discipline was aimed at, or introduced, it had regard to recreation and to immorality of various kinds, but was at no pains to interfere to check the action of the capitalist ${ }^{3}$ or to protect the labourer. From the time when the rise of Puritanism paralysed the action of the Church and prevented her from maintaining the influence she had habitually exerted, ${ }^{4}$ it has been plausible to say that Christian teaching appeared to be brought to bear on the side of the rich and against the poor. The Puritans were probably right as to the most serious evils of the day, and the economic means of overcoming them; they may well have felt that religious duty impelled them to the line they took; but the one-sided way in which they tried to exercise a practical influence has undoubtedly given excuse for attributing to religious men a one-sided view of personal duty.

(c) Some preachers apparently look at the Christianising of society as if it were a very simple thing, which could be carried through in a rough-and-ready fashion without any deep and far-reaching changes, if only men would set about it. It seems to be assumed that the existing machinery

1 See above, p. 128.

2 Growth of English Industry and Commerce in Modern Times, ii. pp. 50, 206.

3 The Edinburgh proclamation against dealing in goods obtained by piracy may perhaps be regarded as an exception (Lavidson and Gray, Scottish Staple at Veere, p. 56).

${ }_{4}$ Gospel of Work, pp. 134-136. 
of society would go on, if doses of Christian sentiment were applied as a lubricating oil to reduce friction, and Christian altruism was turned on as the driving force. But existing society cannot be modified in this fashion; it has for its foundation the maintenance of private property; and exclusive rights are not obviously consistent with the sense of brotherhood. The force which operates, under all forms of competition, is private interest. ${ }^{1}$ It is not possible to fit a new force to the mechanism of society, in the easy manner in which steam-power may be substituted for water-power in a mill. The sense of brotherhood would not necessarily be an effective substitute for the force of selfinterest, the machinery would have to be recast throughout. The force of self-interest induces men to accumulate for future needs, and hence it is possible to have the advantage of a large capital available for society. ${ }^{2}$ It is not clear that the sense of brotherhood would provide as effectually for the accumulation of this main factor in production. Further, the play of self-interest provides an effective discipline against many forms of idleness and waste, though one that is sometimes harsh. It is not clear that the sense of brotherhood would afford opportunity for the exercise of discipline at all. Human society, with no capital and little discipline, exists already among savage tribes, where the sense of kinship and brotherhood is strong; but it is not necessarily more Christian than human society among civilised races. While it is not clear that the sense of brotherhood can be harnessed, so as to do routine and regular work and to maintain material prosperity, there is danger of forgetting that it does not maintain itself, but needs to be fostered and purified. In so far as the sense of brotherhood is merely social, and depends on a common life in similar conditions, it is not necessarily elevating; mutual dependence does not create an atmosphere which will necessarily penetrate within and mould character.

1 See above, p. 149.

2 See above, p. 26. 
There can be no effective reconstruction of society which does not fall back on the personal influence of personal character, and no wholesale methods have yet been devised for achieving this result. ${ }^{1}$

(d) Those who aim at introducing a Christianised society are inclined to lay down laws as rules for action in this society ; the Sermon on the Mount is quoted as if it constituted a code of such laws, and it is insisted that the 'Christian law should be supreme in all the relations of life.' It is possible to read a meaning into this phrase in which it is true, for it may be thought of as a principle for personal action and for controlling individual self-will; but the appeal to a law more naturally suggests the idea of a law of society, to be enforced on others as well; and law in this sense can only deal properly with external acts. Morality becomes superficial when it ceases to be personal : we may all deplore the evils of society, but there is great difficulty in ascribing blame to any individuals. It is easy to indulge in rhetoric about the injustice of society, and to denounce certain classes in the community; but such impersonal confession is only an anodyne to the conscience. To propose to make reparation at the expense of other people, for what we deplore as wrong, is mere hypocrisy; if the maxims of the Sermon on the Mount are not taken as personal, there is a retrogression from the point of view of Christian to that of Jewish morality. Christians are not to be content with judging merely by external acts in regard to any duties; it was the fundamental error of the Pharisees that they thought so much of external compliance and not of the inner disposition; the legal habit of mind is inadequate to Christian requirements. On the other hand, it is only in the case of our own personal lives that we have adequate knowledge of the grounds and reason for any decision; the precise motives which may have actuated other people in their conduct are not really known to us. We are none of

3 See above, p. 20 ; Socialism and Christianity, p. 22. 
us justified in assuming that we can read through a man's external act and attribute a motive to him with any ccrtainty. We cannot pretend to apply the Christian ' law' to other people's lives, and approve or condemn them by this test;- words of warning have been spoken against such presumption, 'Judge not that ye be not judged.' The attempt to interpret the ground of other people's actions is only likely to be an unconscious revelation of dominant motives in our own minds.

When the maxims of the Sermon on the Mount are treated as rules by which we attempt to gauge the Christian character of other people, there is almost certain to be misapprehension ; and it is easy to interpret the most sound and considerate conduct as a disregard of the rule of love to our neighbours. A parish clergyman may be appealed to to pay the arrears of rent of a house painter and his wife; he knows that the man is a confirmed idler and the woman a very unsatisfactory charwoman; he is told that if he does not pay a pound to the landlord at once they will be turned out. It might be simple to pay the money from the poor fund at his disposal and thus to avoid the irritation that will be caused; but his sense of duty as a trustee for the administration of Christian alms may lead him to take another view. He may feel that, under the circumstances, the giving of the money will be a direct condoning of idleness on the part of the house painter and his wife, and that if he gave this money to these people it would be indirectly an encouragement to the less reputable neighbours, and a relative discouragement to the poor who were waging an uphill fight. He decides that he will not respond to this appeal, and pay the arrears of rent; the house painter, who looks at the external act, complains that this professing Christian, who has a good house of his own, allows a poor neighbour to be turned into the street; he can quote the maxim, ' Give to him that asketh thee,' and prove triumphantly that this man does not practise what he preaches; 
but when account is taken of the motives, it appears that the refusal of the clergyman was actuated by a desire to do his duty as a pastor among his people. As Maurice ${ }^{1}$ puts it: "If it has been proved by criminal statistics, or by political economy, that indiscriminate almsgiving is most mischievous, that proof determines this application of the Sermon on the Mount; it shows what would be an unbrotherly act.'

The judgments we pronounce may be mistaken, even in cases where the individual is perfectly free to act in one way or in the other, but in almost all problems of economic life the individuals concerned are not wholly free to act as seems best in their own eyes. ${ }^{2}$ Before condemning any particular act, and still more before attributing a wholly unchristian motive for that act, we are bound to consider how far there has been any practical freedom of choice in the matter. There is always a temptation to waive this preliminary question aside; where there is grave wrong done, we are eager to find some one on whom to fasten the responsibility for the wrong; but in our complex society it is not possible to bring home responsibility in a rough-and-ready fashion. The society in which we live is dominated by the physical conditions of increasing numbers and the difficulty of procuring subsistence; much hardship is inevitable; no one man and no class of men is directly responsible for it, and no one man or class of men is able to remedy it ; the forces that bring it about are too powerful, and cannot be restrained by any one individual. When a man is blamed for harshness, which has arisen in connection with his action, we are bound to consider how far he was free to act in any other way, before we condemn him, or how far he felt himself forced to act in opposition to his own wishes, and with a heavy heart. An employer is the agent through whom the pressure, due perhaps to some incident on the other side of the globe, makes itself felt; he is not always

1 Social Morality, p. 457.

2 See above, p. 117. 
acting out of gratuitous love of tyranny. When a man believes that, in certain conditions of business, it is necessary to dismiss hands, or to lower wages, the decision to take that step may be entirely impersonal, and have reference to the welfare of the employees in the long run. People are unchristian who, because of the hardships which they see and understand, denounce the employer as a monster of greed, while they do not know how the circumstances of the case presented themselves to his mind, and the difficulty he may have had in weighing what was expedient for the district as a whole-not merely for himself. Attempts to treat social problems by applying a supposed Christian law to the conduct of other people can never afford an accurate diagnosis of the mischief in existing society, nor useful suggestions for its improvement. Such attempts will more probably result in uncharitable judgment and railing accusation.

\section{Non-Christian Methods of Reform}

(a) There has been during the last half century an immensely increased activity in regard to many matters of social reform ; and it is most desirable that interest should be aroused and kept alive in all that tends to the improvement of national life, to the diffusing of a higher standard of comfort, and to the introducing of conditions that are more favourable to culture. From the strictly religious point of view, it must be recognised that gross and brutalising surroundings are actively hostile to spiritual influence of any kind, and present most serious obstacles, which we must desire to remove ; and from the merely humanitarian standpoint, the same desire for removing hindrances to the elevating of character must also be felt. The end in view is undoubtedly good, but there may be question as to the wisdom of the means which find favour at present. The methods of social reform which are most in vogue in the 
present day are non-Christian in character; they do not rely on the effect of holding up a high ideal and on the attraction it exercises on men personally; they aim instead at compelling men to do at least a minimum of duty, and at trying to stamp out evil, or hindering men from falling into it. These may be very right and wise things for the State to attempt, and for philanthropists to try and carry out, but they are not specifically Christian. They are rightly described as non-Christian; they are not an appropriate theme for Christian preaching, nor are they properly regarded as Christian work ; and though they may be pursued like other secular duties from Christian motives and in a Christian spirit, there is, nevertheless, a danger of their being advocated in an unchristian spirit.

There has been a great increase in the amount of State compulsion in regard to many matters; as, for instance, the notification of disease, the insistence on vaccinationeven with the relaxation which took place in 1898,- and still more the introduction of compulsory elementary education. These appear to be most desirable objects; but it is clear that the action of the State is directed simply to the attainment of certain results without reference to the effect on the character of the human agents concerned; as the sphere of operation of this kind of State action extends, there will consequently be less and less opportunity for the development of character. Granting that it is desirable that all the children in the community should be able to read and write, and that this result can best be secured by compelling parents to send their children to school, the result has probably been attained at the expense of a certain loss of character. A very large number of parents did realise that it was their duty to send their children to school, and took some pains in selecting what they thought the best school, either because of the character of the teaching or of the children who frequented it. Since the system of compulsion has come in, the parent is apt to 
think that he has done all that he need when the child has received the education on which the State insists, and he has had no occasion to exercise thought on behalf of his child in respect of education, or to interest himself in it in any way; it has been taken out of his hands. The instruction of the children may go on better; but the opportunity for the exercise of personal parental duty is curtailed, and thus the education of the parent in practising a duty towards his children suffers; he has less chance of learning to be interested in their welfare, and continuing to try to promote it. When this duty becomes a matter of State compulsion, and not of individual action, there is a danger that the sense of parental responsibility may be lowered. In the same way, the transference of the duty of feeding children to school authorities is quite likely to have the result that the children are better fed, on more wholesome and better cooked food, and this is a definite gain; but it is attained at the cost of diminishing the sense of parental responsibility, and this is a loss which should not be forgotten.

We have experience of long standing to show how a duty changes its character when it is done under State compulsion. For some time before the Norman Conquest the duty of paying a tithe of the produce of the soil for religious objects was insisted upon by civil authorities; and in Angevin times the last element of voluntariness was excluded, as no choice was left to the proprietor in regard to the question to what religious purpose his tithe should be paid. ${ }^{1}$ It became a tax, much like any other tax, when the obligation could be enforced under civil sanctions. In the same way, the contributions for the poor changed their character in Elizabethan times; they ceased to be voluntary alms, and became a poor rate which could be enforced by authority. The results aimed at were secured in both cases; provision was made in every part of England for the maintenance of religious worship and ordinances ; and

1 Cure of Souls, p. 44. 
the Elizabethan system seems to have been wonderfully successful in dealing with the problem of pauperism as it existed in the sixteenth century. ${ }^{1}$ But in neither case was there any educative effect on the persons who contributed, so far as religious and moral character was concerned. The imposition of a tax inclines a man to think he has done all his duty when he has paid it, and leaves him disinclined to do more ; whereas the interest that is roused, by trying to do a little voluntarily, may increase and lead to the formation of a more generous view of his obligations.

From a strictly Christian standpoint, the trend in favour of transferring responsibility to the State must be viewed with regret, even though the results aimed at are well worth trying for. But personal duty, and the fostering of higher ideals of personal duty, is the special sphere where Christian influence has an opportunity of coming into play. With every increase of compulsion, this sphere is curtailed; there is less field for the play of the personal will, and for the effort to do personal duties; and the region within which the power of Christianity operates most directly and forcibly is correspondingly reduced.

(b) In regard to compulsory education, a minimum of duty can be insisted upon; but there are many other matters about which it is impossible to insist on any external performance of a moral duty, or to define any minimum of duty which ought to be enforced from all. In such cases the attempt to force men to do their duty must be abandoned, and external pressure can only be brought to bear by the State to limit or to put down what is bad. Voluntary action in regard to morals may be easily diverted to follow too closely on the same line. There are voluntary societies for the promotion of temperance, but insensibly their activities have come to be directed against the evil of intemperance in one of its forms. Spenser, in his Faery Queene, regarded drunken-

1 Growth of English Industry and Commerce in Modern Times, ii. p. 50. 
ness as a form of bodily self-indulgence, and made it characteristic of the antagonists of chastity: while the knight of temperance is the representative of a well-ordered life, from which all exaggerations of thought and speech are excluded. In our day the classification of the virtues has been much altered, and such a change could hardly have taken place unconsciously, if attention had been increasingly given to the Christian duty of trying to foster what is good, as distinguished from merely suppressing what is evil. When the nature of temperance as a virtue is obscured, the difficulty of trying to cultivate it is increased.

When activity is thus diverted from the positive aim of trying to set forth the good, to the negative effort of stamping out evil, the moral life suffers. Instead of aiming at realising a high ideal of conduct, we are tempted to be content with avoiding some particular act, and treating that as a criterion of a virtuous or of an evil life. There is a danger of fixing on anything in the world, such as alcohol, as being inherently evil ; and in treating abstinence from this particular thing as a definite mark of virtue. Much morality, Jewish, Buddhist, and Mohammedan, has tended to place right and wrong in the things outside us, which can be roughly classified as good and evil ; but Christianity directs attention to the inner disposition, as that which consecrates the use of the thing, or turns what is in itself indifferent into an instrument for good or for evil. When the Christian conception of the importance of the inner disposition is lost sight of, the personal life will suffer. When externals are over-rated, there is a danger of selfconsciousness and of setting oneself up as an example of some form of self-denial; and this affectation is futile in those cases where from taste and temperament the abstinence involves no self-denial. That it is important to avoid external acts which are wrong is true enough ; it was right for the Pharisees to be strict about detecting breaches 
of God's law and endeavouring to render it effective in all the details of life ; but too exclusive attention to external conduct, unbalanced by constant care to render the inner life consonant to the will of God, is a dangerous habit of mind into which Christian men in all ages have been tempted to fall.

(c) The step from that which is non-Christian in morality to that which is unchristian need not be a very long one. There are two sides from which we may see that efforts to concentrate attention upon evil, and put it down, are quite alien from the spirit of Christ's religion.

A crusade against evils of any kind, which exist in society, involves those who take part in it, in habitual thought about the evil they deplore, in continual efforts to trace out its ramifications, and to make men realise the horror of it. But this attitude of mind is unwholesome. St. Paul definitely recommends us to think of what is honest and of good report, and not to be continually dwelling on what is corrupt and corrupting; it is well to be simple concerning evil. This is more especially true in regard to sins of impurity $;^{1}$ the indulgence of idle curiosity is unwise; there are many things in this world that it is quite unnecessary to know about, and in regard to which there can be no duty to diffuse knowledge. Attacks on corrupt literature may be carried on so as to advertise it ; and it is a duty for Christians who are living in an evil world to try to keep their own minds pure so far as may be.

Again, a crusade against evil involves the use of strong language and vivid colours ; revolutions are not made with rose water, and the attack on what is plainly mischievous seems to be an occasion when a man may do well to show that he is angry. But this, again, is unchristian; those who are most clear that they are striving to serve God, by denouncing certain forms of selfishness, or greed, or vice, have much need to be on their guard lest they are serving 
Him by unhallowed means. The denunciation of evil almost necessarily involves the accusation of certain persons as guilty ; and in using exaggerated language, or in attributing evil motives, there is serious danger of bearing false witness against a neighbour. The exaggeration is imprudent as a matter of policy ; it discredits the agitation with which it is associated. But it is difficult even to make unexaggerated and truthful accusations in a Christian fashion : the Christian principle is to malse the best of men, in the hope of calling out the latent good that may be in them. 'Charity covers a multitude of sins,' and there are few Christian men who are so entirely innocent of all offence that they have a right to take up stones and cast them, even at a neighbour who has gone utterly wrong. Many publicans, for instance, are at pains to keep their houses respectable; and wholesale denunciations of the class only tend to discourage those who are trying to conduct their business rightly; while the temptation to recrimination is very strong. Those who are without, have a keen sense for noting inconsistencies on the part of professing Christians. The unchristian elements in agitations against particular forms of vice are only too likely to be made the occasion for disparaging religion altogether : the world at large is not prepared to make allowance in this matter, or to distinguish between the secularised Christianity of the day and the Christianity of Christ. 


\section{CHAPTER III}

\section{THE CHRISTIANITY OF CHRIST}

(a) IN regard to all questions as to the duties of Christian men in any place and in any age, there is only one court of appeal. We are bound to inquire into the mind of Christ as it is set before us in His teaching, and also in His personal example. We need not fear that we are going far astray if both lines of inquiry conduce to the same result.

The main body of Christ's teaching in regard to social duties is to be found in the Sermon on the Mount; it is to this discourse, above all others, that appeal is made by those who advocate the claims of Christianity as a Social gospel. ${ }^{1}$ Christ's discourses do inculcate brotherliness, and contain teaching on many of the duties of ordinary life. But a very little consideration will enable us to see that our Lord's teaching is not merely humanitarian. It takes all its force and effectiveness from the manner in which the thought of the Eternal God, the Father of all, is brought to bear upon everyday conduct. The desire to set forth the goodness of God is the motive for right action : 'Let your light so shine before men, that they seeing your good works may glorify your Father which is in heaven.' The thought of that Heavenly Father sets the standard at which men are to aim. 'Be ye therefore perfect, even as your Father which is in heaven is perfect.' It is to the Father that men must look for the reward of all that is good. "Thy Father which seeth in secret, Himself shall reward thee openly.'

1 See above, p. 208. 
The whole of this code of brotherly and neighbourly conduct is built upon a religious basis ; and religion is a personal thing. The direct appeal is for personal devotion to God, though indirect results in benefit to society may be looked for too.

The Sermon on the Mount is throughout a protest against the inadequacy of a morality that is chiefly, or merely, external, and is expressed in and approved by a conventional social system. The Beatitudes insist on the blessedness of those who are poor in spirit and meek and pure in heart; this praise of inner dispositions and graces sets the tone of the whole. We are taught that obedience to God's will explains and amplifies the Mosaic rules for compliance with His commandments; and that inner disposition is the primary and important thing in such duties as prayer and almsgiving. The whole idea of Jewish morality, which had aimed at securing a divinely ordered society, is abandoned, and the Lord's teaching appeals to the individual heart and conscience. The man who hears His words and does them is steadfast in his course through life; and there was frequent insistence on this view as to the importance of the inner life in His subsequent preaching: it is the evil which is in man's heart, and finds expression in his thoughts or words or deeds, that really defiles him.

The contrast in this respect between Christ's teaching and that of Judaism comes out especially in regard to another point-the attitude which is taken towards the rich. There had been a good deal of denunciation of the rich in old times, for their oppression; and St. James carries on this tradition in his scathing rebukes. Among the disciples, however, there was also a tendency to view the rich favourably, especially if they were generous in the use of their goods ; in any case, they were under little temptation to set aside propriety of conduct and external respectability; it is the poor man who is most readily tempted to 
crimes that shock society. But our Lord neither passes a specially lenient judgment on the rich, because of their external correctness, nor denounces them for merely being rich : He fastens on the true inwardness of the evil. The rich are specially exposed to the danger of God-forgetfulness, and of concentrating their attention and interest on earthly things : but it is the covetousness or the arrogance, the spite or the pride which are engendered by a love of earthly things, that is the evil. "Ye cannot serve God and mammon': but the poor man, who takes anxious thought, and whose mind is absorbed in earthly wants, had need of this warning, as well as the rich man, whose cares and anxieties would divert his mind from spiritual things. Riches are, according to His teaching, not so much an evil as a danger, because they are so absorbing. 'How hardly shall a rich man enter into the kingdom of heaven,' not because of the external accident that he is rich, but because of the danger that he will trust in his riches.

But more than this; the Parable of the Tares is a warning for all time against the mistake of looking on the kingdom of heaven as an earthly realm from which evil is to be eradicated. The breach with Judaism is complete ; 'Thou shalt not suffer a witch to live' was an appropriate maxim for an earthly theocracy. But Christ teaches not merely tolerance of things that we do not like, but the toleration of that which is plainly and certainly evil. The tares were there; they were thoroughly bad, an enemy had sowed them; they were destined to be burned at last. But they were not to be rooted up by human hands, lest the wheat should be injured too. No movement which begins with drastic efforts to purify society, in the hope of removing contamination from individuals, is consistent with the teaching of this parable.

(b) The aspect of our Lord's ministry which attracted most attention at the time, and has impressed the readers of the Gospels in all ages very vividly, was His work in 
connection with the healing of diseases, and the satisfying of human hunger by the feeding of the multitude. These mighty works, and the immediate relief they afforded, were never done for their own sake; to our Lord's mind they were entirely subsidiary to the spiritual aims of His ministry. ${ }^{1}$ It was His aim that the manifestations $\mathrm{He}$ gave of divine power in the physical sphere should force men to realise that God was indeed in the midst of them, and to turn with all their hearts to the God who had so wonderfully intervened in their behalf. But for the most part they accepted the physical boon, as all they cared for, and were not awakened by such deliverance to any fresh sense of God's nearness and of His care for them. The miracle of the feeding of the five thousand left the multitude apathetic as to the revelation of God which He had come to declare, though they were ready to seek Him because they did eat of the loaves and were filled. Again and again $\mathrm{He}$ was unable to do any mighty work, because it was so clear that the people would not be able to rise to a true appreciation of the character of His mission. Of the ten lepers-all of whom had so far relied on Him that they had started to show themselves to the priest before any signs of healing appeared-only one was impressed with a real sense of reverence, at divine condescension in healing him, and returned to give glory to God. At Nazareth, He could not respond to the demand that He should behave in a neighbourly fashion and perform cures similar to those which $\mathrm{He}$ had effected in other towns ; since they thought of Him merely as a wonder-working neighbour, the granting of their request would only have been a further obstacle in the way of their learning to appreciate Him aright.

The object of His healing was to teach men to know and feel that God is not far from any one of us, but is a loving Father to whom we can turn at all times. The first miracle was performed, not merely to add to the merriment

1 T. Farmer Hall, Christian Healing. 
of a feast, but to show forth the glory of God : the raising of Lazarus was accomplished, not merely to assuage sorrow, but that the glory of God might be manifested. This spiritual aim was directly present to His mind all through His life ; there were multitudes who were sick and suffering for whom $\mathrm{He}$ did nothing at all ; if the relief of physical evil had been a primary or even a secondary object with Him, this is inexplicable; the selection of some sufferers, and reluctance to help generally, are unintelligible, unless we recognise that the healing was not an end at all with Him, but only a means by which He sought to bring a sense of spiritual realities and spiritual truths home to the sufferers and their friends.

His unwillingness to take an active part in secular improvement, on its own account and for its own sake, comes out very strikingly on the occasion when $\mathrm{He}$ was appealed to with the request that $\mathrm{He}$ would interfere with regard to the division of an inheritance. He disdained the part of a judge or an arbitrator, and He declined to interfere. It might have been supposed that $\mathrm{He}$ would have been ready to enforce justice, if the claim were good, or to rebuke covetousness if the man's rights had been sufficiently recognised. But $\mathrm{He}$ simply waived it aside. The whole dispute was about earthly things, and He did not see how to use it as a stepping-stone to help the disputants to apprehend spiritual realities.

While thus disclaiming any mission to deal with such matters, He was careful to recognise the civil authorities, and to show respect to their office. There were many defects in the government of the day, both Jewish and Roman; but He enjoined obedience to those who sate in Moses' seat ; and by paying tribute, He set an example of submission to the demand of the government, as being at the same time a form of obedience to God. His habitual practice, on one occasion after another, reinforces the teaching He proclaimed in the Sermon on the Mount and in 
the parables. He had come to set forth the glory of God and to manifest His Father's character and will among men ; this was His work ; in so far as physical healing and the relief of suffering could conduce to this spiritual mission He engaged in them, but they were not things for Him to take upon Himself apart from the one great object of His life.

(c) The disciple is not above his Master; we must beware of criticising our Lord's conception of His mission as inadequate, and of claiming that we can supplement it by developing new activities in His name, when He himself refused to sanction them. There may be much eager talk about Christianity and much activity by professing Christians that He will refuse to recognise as emanating from Himself. The Church can only exercise a wise influence on social problems by being true to her Master, and striving to carry on His work as $\mathrm{He}$ saw it, and as $\mathrm{He}$ committed it to her charge.

The Church indeed consists of men, each of whom, as a citizen of an earthly kingdom, is called upon to do his political duties, as well as his other duties, in the name of the Lord Jesus. For ordinary purposes, in ordinary life, it may not be important, or even perhaps possible, for a man to distinguish that which is incumbent upon him as a citizen of an earthly realm from that which is incumbent upon him as a child in the family of God. But the distinction is of vast importance in regard to those who are called to office and ministry in Christ's Church. The terms of their commission lay down the limits of what they are to do by Christ's authority; they have no commission to put the affairs of society right, or to eradicate the evils in this present naughty world. In the gospel of the grace of God, they have committed to them the supreme means of touching men personally, and inspiring them with high but practicable ideals. This is the grandest work to which any man can give himself; and it is a miserable thing if he 
fails to put his best energies into this task, and prefers instead to compete with fournalists and politicians in guiding some project for social reform. It is to forsake the fountain of life, and to strain at accomplishing some apparent improvement by taking up implements that are less certain and less effective, even for securing human welfare, than the means of grace instituted by Christ Himself. In his official capacity, as called to preach the gospel of Christ, the minister is bound to set forth that which is good and to strive to attract men personally. The Old Testament prophetic office, with its denunciations of evil-doers, survived in St. John the Baptist's time, and his bold rebuking of vice; but it is at all events a very subordinate part of the Christian minister's duty, and one which is not to be discharged in a wholesale fashion without serious risk of alienating those whom it might have been possible to win. It is needful to look to the terms of Christ's commission, both as to the duties that are to be done and the manner of doing them. He sent His apostles on evangelistic work, and bade them administer the sacraments and exercise pastoral care ; but He did not enjoin them to agitate for social reforms.

Since the task which is given us to do is spiritual, it can only be accomplished by spiritual strength and through spiritual means. We wrestle not against flesh and blood, but against principalities and powers. There is need of divine courage and divine wisdom; the strange bustle and confusion of modern life is a constant call to cease from bandying half-truths, and to seek for the help of that Divine Spirit who can clear our eyes from passion and greed, and by helping us to see the various elements in due proportion, can lead us into all truth. 


\section{BIBLIOGRAPHY}

Political Economy.-The most recent English treatise on the whole subject is Professor J. S. Nicholson's Principles of Political Economy (1893); Mr. C. S. Devas's Political Economy, in the Stonyhurst College Series (2nd edition, 1901), is an excellent handbook. The great classics on the subject are not out of date : Adam Smith's Wealth of Nations has been admirably edited by Dr. E. Cannan, and J. S. Mill's Principles of Political Economy, by Professor W. J. Asbley (1909). For the literature of the subject it will be found convenient to compare Professor G. Schmoller's Grundriss der allgemeinen Volkswirtschaftslehre (6te Aufl. 1901).

Economic History. - The references in W. Cunningham's Essay on. Western Civilisation in its Economic Aspects-Vol. I. Ancient Times (2nd ed. 1902), and Vol. II. Mediceval and Modern Times (1910)-supply a guide to much of the literature of the subject. More detailed information in regard to English history will be found in W. Cunningham's Growth of English Industry and Commerce-Vol. I. Early and Middle Ages (5th edition, 1910); Vol. II. Modern Times (4th edition, 1907).

\section{PART I}

Malthusian Principle.-The second and subsequent editions of T. R. Malthus's Essay on the Principle of Population (1803) expound the theory in a complete form. Compare also J. Bonar, Malthus and his Work (1885). On the evil of neo-Malthusian proposals for the artificial limitation of births, compare C. Coppens, Moral Principles and Medical Practice, p. 117 (3rd edition, New York, 1897), and $\mathrm{H}$. Wegener (Wir jungen Männer, 1906).

Law of Diminishing Return.-This was formulated simultaneously by T. R. Malthus (An Inquiry into the Nature and Progress of 
Rent (1815) and by Sir E. West (Essay on the Application of Capital to Land). Compare Dr. E. Cannan on the 'Origin of the Law of Diminishing Return' in Economic Journal, ii. 53.

Socialism.-The English followers of K. Marx, Das Capital (2te Aufl. 1872), may be conveniently divided into two groups. Mr. H. M. Hyndman (Economics of Socialism, 1896) insists that justice demands the immediate reconstruction of society. Professor K. Pearson (Socialism in Theory and Practice, 1887) repudiates the demand thus made for immediate justice, and, like Mr. H. G. Wells (New Worlds for Old, 1908), advocates the gradual reconstruction of society on Socialist lines.

Native Races.-There are so many conflicting statements on this subject that it is difficult to get reliable information, but reference may be made to the results of the official inquiry in the 'Report from the Select Committee on Aborigines (British Settlements),' in Parliamentary Papers, 1837, vii. 1. See also L. Alston, The White Man's Work in Asia and Africa (1907).

Indian Manufacture.-On the artistic quality of textiles, metal working, etc., compare Sir G. C. M. Birdwood's Industrial Arts of India (1880). The wisdom of English economic policy towards India was impeached by the late Mr. Justice Ranadé in Essays on Indian Economics, i. and iv. (Calcutta, 1899).

Civil Authority. - The doctrine of the Church of England was expressed in the Homilies (1562), and more fully discussed by Hooker (Ecclesiastical Polity, 1593) and Archbishop Ussher (The Power communicated by God to the Prince, 1661).

\section{PART II}

Economic Functions of Government.-Justice and Equality as aims of governmental action are discussed by $\mathrm{H}$. Sidgwick (Principles of Political Economy, Bk. iii., 2, 4, 6, 18); and on State Interference compare H. Sidgwick, Elements of Politics, chap. ii., 1901. On the importance of Security see the Duke of Argyll, The Unseen Foundations of Society.

Unemployment. - The discussion of the subject by W. H. Beveridge (Unemployment, 1909) may be usefully supplemented by reference to the articles by Mr. H. Stanley Jevons on the 'Causes of Unemployment' in the Contemporary Review, 
May, July, and August 1909. Compare also Professor J. S. Nicholson, A Project of Empire (1909).

Wastes of Competition.-Compare Professor J. W. Jenks, Trust Problem, 1903 ; also the 'Progress of Socialism in England' in the Contemporary Review, xxxiv., January 1879.

Usury and Interest.-For the grounds of the mediæval prohibition, and the reasons for its breaking down, see Professor W. J. Ashley, Introduction to the Economic History of England, Parts I. and II. Compare also W. Cunningham, Use and Abuse of Money (1891).

Public Management of Business.-On the Nationalisation of Land, see H. George, Progress and Poverty (1885); also the criticism by the Right Hon. A. J. Balfour, entitled, 'Land, Land Reforms, and the Nation,' in the Industrial Remuneration Conference Report (1885). On the Nationalisation of Railways, compare W. M. Ackworth (The Railways and the Traders, 1891) and E. A. Pratt (Railways and Nationalisation, 1908). The practice of Municipal Trading is criticised by the Hon. R. P. Porter (Dangers of Municipal Trading, 1907) and Lord Avebury (On Municipal and National Truding, 1906).

Classical School.-The Principles of Political Ecomomy (1843), by J. R. $\mathrm{M}^{\prime} \mathrm{C}$ ulloch-a man of great learning and keen interest in practical affairs-shows the strength and the characteristic defects of this group. Ricardo's treatment of Economics, as developed by K. Marx (Das Capital), has been the startingpoint of modern Socialism ; but Professor Gonner ('Introduction' to Ricardo's Principles of Political Economy and Taxation, 1891) contends that Ricardo has been much misunderstood.

Small Holdings and Allotments.-On the conditions of business success and failure, see H. Levy, Entstehung und Rückgang des landwirtschaftlichen Grossbetriebes in England (1904); also the 'Report on Commons Inclosure,' answer 514 f., 1207 f. in Parliamentary Papers, 1844, v., and Labour Commission Fourth Report, Parliamentary Papers, 1893-94, xxxix. pt. ii. 283. Mr. Jesse Collings insists on the political and social benefits of a Peasant Proprietary (Land Reform, 1908); compare also Baudrillart, Les Populations agricoles de la France, iii. 3 (1885). On the importance to the labouring poor of opportunities for 
subsistence husbandry, compare 'Back to the Land' in Economic Review, xvii., Oct. 1907. On difficulties of management, see Parliamentary Papers 1843, vii. ('Report on Allotments'), and 1844, v. ('Report on Inclosure,' Index s.v. Allotments).

Modern Social Ideals. - In recent times the ideals which were formerly regarded as merely utopian have been widely adopted as practicable aims which it is thought possible to attain gradually with the aid of science. Godwin, by his advocacy of equality as furnishing the best conditions for the improvement of morality (Political Justice, 1793), and Comte, by promulgating the religion of humanity, have contributed to this result. On the range within which positive scientific guidance can be given, and on the persons who are susceptible to it, compare $K$. Pearson (Enthusiasm of the Market Place and of the Study, 1885, and The Moral Basis of Socialism, 1887). On the philosophic basis of this teaching, see Dr. E. Caird, The Social Philosophy and Religion of Comte (1885), also W. Cunningham, 'Positivism' in Path towards Knowledge (1891).

\section{PART III}

Christian Duty of Work. - This has been admirably treated by I. Barrow, Of Industry (1693); see also W. Cunningham, The Gospel of Work (1903).

Christian Duty of Owners of Property.-Dr. G. Ratzinger, Die Volkswirthschaft in ihren sittlichen Grundlagen, cap. ii., 1881, and Professor C. Périn, La richesse dans les sociétés chrétiennes, 1868.

Christian Socialism.-This term was used by J. M. Ludlow, F. D. Maurice, and Charles Kingsley, who tried to organise co-operative workshops in London (Tracts on Christian Socialism, 1851. See the note in Mr. F. J. Furnivall's hand in the British Museum copy, 08275 e. 33) ; their aims were wholly constructive. The name has been adopted by Dr. W. Rauschenbusch (Christianity and the Social Crisis, 1907) and others, who, while retaining a Christian standpoint individually, join with modern Socialists in their destructive criticism of existing society.

Puritanism.-The manner in which Puritan teaching helped to build up the character of men of business is discussed by $G$. v. Schulze-Gävernitz, Britischer Imperialismus (1907), p. 47 f. 


\section{N D EX}

Accumolation, 22, 25, 109, 128, 148, 161, 207,

Adaptation, 28.

Adulteration, 105.

Africa, 22, 27, 30, 31, 88.

Agriculture, 6, 38, 40, 84, 100, 144, 172.

Alabama Case, 57.

Alaska, 88.

America, 31, 44, 144, 174. Central, 29, 40; see also Indians, United States.

Angevins, 127, 213.

Apprentice, 114.

Arbitration, 57.

Arkwright, R., 103.

Army, 52, 56.

Artisan, 39, 109 f.

Assimilation, $34 \mathrm{f}$.

Assize, 68.

Assyria, 29.

Atlantic, 30, 57.

Augustine, St., 17.

Australia, 44.

Bacon, Francis, 60, 174.

Balance of Trade, 162.

Bank of England, 178 n.

Barbarians, 28, 184.

Bargains, Hard, 105.

Barter, 24.

Beatitudes, 219.

Bedford, Duke of, 138, 145.

Benedictines, 184.

Birkenhead, 140.
Black Death, 105.

Bloomsbury, 145.

Board of Trade, 108. of Local Government, 129.

Briggs, Messrs., 131.

Britons, 38.

Brotherhood, 153, 182, 207.

Buddhist, 215.

Burleigh, Lord, 60, 178.

Cambridar, 100, 113.

Cambridgeshire, 100, 102, 135.

Canada, 44.

Capital, 25,88 f., 103 f., 123 f.

- Personal, 193.

Carlyle, T., 164.

Cashmere, 39.

Chalmers, Dr., 9.

Character, 9, 18, 20, 62 f., 176 f., 183 f., 198 f., 207 f.

Charles I., 58.

Charles II., 51.

Chinamen, 28, 30.

Christendom, 41, 203.

Civil War, 8, 56 .

Clarendon, Earl of, 62.

Classical Economists, 158, 163, 204.

Clough, A. H., 41.

Cobden, R., 169.

Coinage, 51.

Colonial Nationalism, 37.

Colonisation, 31.

Communications, 30, 38, 169.

Communism, 22.

Company, 114, 131, 192. 
Competition, 31, $104 \mathrm{f}$.

Constitution, 55, 62.

Co-operation, 74, 89.

Co-partnership, 131.

Corn Laws, 169.

Cosmopolitanism, $37 \mathrm{f}$.

Craft guilds, 106, 114.

Craftsmen, 106, 114 f., 121, 171.

Credit, 51, 70, 87, 128.

Crom well, 0., 35, 43, 61.

DACCA, 39.

Danegeld, 139.

David, King, 203.

De Beers, 33.

Decadence, 29, 59, 65, 82 .

Dickens, C., 164.

Discipline, 17, 42 f., 152.

Division of labour, 24,74 .

ECClesiastes, 186.

Economic forces, 27, 38, 40.

- law, 164, 166.

- science, $4,158 \mathrm{f}$.

Education, 34, 212.

Edward I., 100, 178 n.

Edward III., 102, 115.

Edward VI., 51.

Egypt, 5, 32, 37.

Elizabeth, Queen, 49, 51, 115, 129, $150,168$.

Emperor, 177.

Empire, British, 36 f., 43, 90, 169.

- German, 90.

Roman, 26, 92, 184, 208.

Enclosure, 112.

Energy, 151.

Enterprise, 131, 151.

Equality of opportunity, 149, 151.

Exchange, 24 f., 51, 92, 105.

- value, 158.

Exchequer, 51.

Expediency, 66.

FAOTORIES, 105, 135.

- Acts, 166.
Faery Queene, 214.

Faith, 187.

Fall, 186.

Family, 25, 29.

Food-supply, 1, 8, 38, 89, 150, $167 \mathrm{f}$.

France, $61,173$.

Franks, 27, 29.

Furness, Sir C., 131.

Gaping GULF, 49.

Gaul, 28.

George III., 152.

Germans, 36, 90.

Gig-mills, 119.

Godwin, W., 174.

Greece, 37, 186.

Guiana, 33.

HADRIAN, 81.

Hamilton, A., 89.

Happiness, 20.

Harington, J., 174.

Henry II., 35.

Hindu, 28, 30.

Hobbes, T., 27.

Holdings, Small, 87, 112, 171.

Hours of labour, 61, 90, 96, 118.

House of Commions, 135.

Housing, 101 f., 133 f.

Huns, 27.

Hyndman, H. M., 25, 26.

IMPROVIDENCE, 27.

Incarnation, 180.

Increment, 22, $143 \mathrm{f}$.

India, 5, 39, 71 n., 109.

Indian, North American, 22, 24, 27 . 30.

Infidels, 200.

Inquisition, 68, 204.

Interest, $52,71,92,125 \mathrm{f}$.

Interlopers, 106.

Ireland, 23, 35, 170.

Islam, 30.

Israelite, 73.

Italy, 28, 35. 
J

James I., 128, 147.

Jevons, W. S., 93.

Jews, 200.

John, St., Baptist, 224.

Judaism, 137, 203, 219.

Justices of Peace, 137.

KIMBERLEY, 33.

LABOUR, indentured, 33 .

Slave, 33, 182; see Division. Hours, Wages.

Laisser faire, 52, 90, 107.

Land, Uses of, 137 ; see Increment, Rent.

Law of Diminishing Return, $3 \mathrm{f}$. Population, 3 f. ; see Economic.

Lazarus, 222.

Leisure, 24, 96, 153, 159, $187 \mathrm{f}$.

Lenthal, Sir J., 61.

Locke, J., 59.

Lombards, 27.

London, 8, 104, 141.

London Gazette, 124.

Lords Lieutenant, 137.

MAOHINERY, 23, 39, 121, 172.

Mahometan, 31, 215.

Malthus, 2, 9, 91.

Mammon, 201.

Man, economic, 19.

- as animal, 1 f., 21.

- as rational, $5 \mathrm{f}, 174$.

Manchester School, 53.

Manufactures, 84, 88, 103, 116, 122. Indian, 39.

Marco Polo, 30.

Marx, K., 25.

Maurice, F. D., 73, 201, 210.

Merchant of Venice, 126.

Middle Ages, 6, 30 46, 106, 112, 126, $171,178,203$.

Mill, J. S., 107.

Milton, J., 61.

Mining, 32.
Money, 24, 51, 70, 104, 117, 123 f., 192 f., 205 f.

- measurement, 93.

Monk, General, 62.

Monopoly, 85, 108, 120, 134.

Monte Carlo, 195.

More, Sir T., 174.

Moses, 222.

Municipal trading, 132.

NAPOLEON, 51, 64, 129, 169.

Navy, 52, 61, 102.

Nazareth, 221.

Negroes, $31,35$.

Nelson, Lord, 102.

New England, 58.

New Hampshire, 58.

New Lanark, 174.

New River Co., 147.

New Zealand, 31.

Nicholson, Prof. J. S., 39 n., 163.

Norman Conquest, 137, 213.

Obediknce, 49, 59, 222.

Old Testament, 186, 224.

Oneida Reservation, 24.

Owen, Robert, 174.

Ozra, Princess, 179.

PAPACY, 46, 206.

Parable of Tares, 220.

Parliament, 37, 50, 61.

- Long, 61 ; see House of Commons.

Passions, 17, 35, 41, 65, $183 \mathrm{f}$.

Pasture, 6.

Patriotism, 37, 73, 179.

Pauperism, 9, 92, 214.

Pessimism, 5.

Petty, Sir W., 162.

Pharaohs, 5, 7 .

Pharisees, 208, 215.

Philanthropists, 41, 164, 199, 202, 212.

Philosophy, 19, 170, 186, 205.

Pitt, W., 74.

Polygamy, 29. 
Population, Redundant, 9, 91.

Law of, $3 \mathrm{f}$.

Portuguese, 31.

Prodigal, 19.

Profit, $123 \mathrm{f}$.

Protectorate, 61.

Proverbs, 186.

Psalms, 73.

Public spirit, $50 \mathrm{f}$.

Punishment, 47, 52, 66 f., 75, 101, 202, 205.

Puritans, 50, $204 \mathrm{f}$.

RACEs, Native, $21 \mathrm{f}$, $180 \mathrm{f}$.

Reformation, 115.

Rent, 104, 137 f., 209.

Revenue, 51, 97, 127, 137, 214.

Revolution, 168, 170, 178.

Reward, 33, $82 \mathrm{f}$. ; of labour, 99 ; see Profit, Rent.

Scot, 30.

Scotland, 23, 37, 85, 204.

Scripture, 184, 191.

Self-discipline, 184, 191.

Self-sacrifice, 113, 153, 180, 185.

Sermon on Mount, $208 \mathrm{f}$.

Settlers, 37.

Sinking Fund, 71.

Skill, 2, 6, 21, 38, 72, 91, 109, 111, $151,160,171$.

Slaves, 34, 62, 82, 99, 182.

Sluys, 102.

Smith, Adam, 38 n., 69 n., 95, 147, 158, 162.

Solomon, 203.

Spain, 28, 40.

Spenser, Edmund, 214.

Spinning jennies, 119.

Standard of comfort, 8, 32, 36, $79 \mathrm{f}$., 100f., 118f., 141f., 168, 173, 192, 211.

Standard Oil Company, 131, 134.
Stevenson, G., 103.

Stock Exchange, 195.

Struggle for existence, 4, 7, 21, 27, $39 \mathrm{f}$.

Stuart kings, 43, 150.

Stubbe, J., 49.

Suffolk, 119.

Sweating, $121 \mathrm{f}$.

Swedes, 36.

Tammany Hale, 55.

Taxation, 47, 64, 69 f., 127, 139 f.

Thorney, 138.

Tillage, 2, 5, 7, 22, 102, 139 168, 171.

Trade Unions, $118 \mathrm{f}$.

Tradition, 59.

Trafalgar, 102.

Trusts, 131.

Turks, 200.

UNEMPLOYMENT, 92, 121, 205.

Union, 37.

United States, 11, 35, 36, 46, 54 f., 89, 144.

Utilitarianism, 54 .

Utility, 94, 158.

Utopias, 174.

VALUe, 24, 93 f., 145, 163.

Vandals, 27.

Village community, 6 .

Virginia, 34.

Virility, 29.

WAGES, $4,33,78,105,117,122,168$, $172,205$.

Wages fund, 166.

War, 42 n., 47, 57, 64, 69, 71, 88.

Watt, J., 103.

Wealth, 23 f., 53. Aggregate, 96.

Welfare, 72 f., 81,85 f., 119, 177.

Witches, 58, 204, 220. 


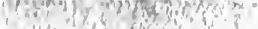

"I, of fivis

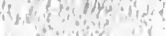




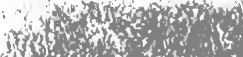

1.

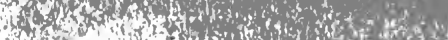

Nond

Not

sula

Qtign

ind

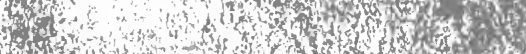

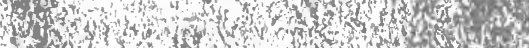

150

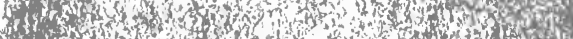

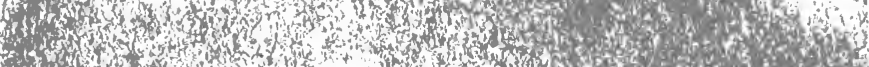

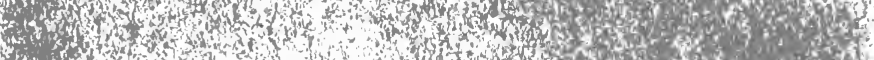

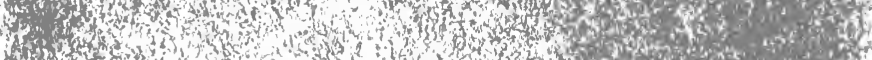

Tho

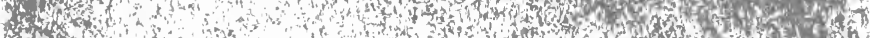

s.tinn

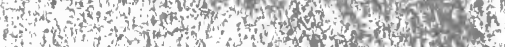

teste

Axtor

com

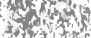

If

int

Arto:

ing

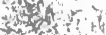

(t)

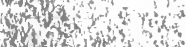

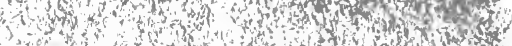

now

IST

How

s.t.

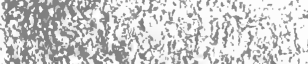

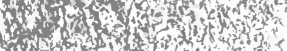

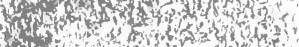

11.

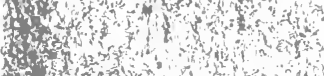

m

at ${ }^{2} \mathrm{w}^{2}$

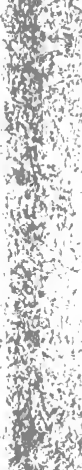
18.

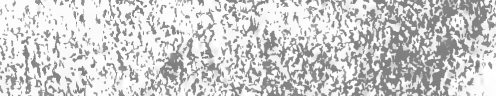

ins

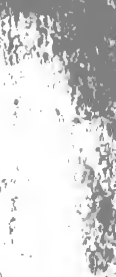



questions

PLEASE DO NOT REMOVE CARDS OR SLIPS FROM THIS POCKET UNIVERSITY OF TORONTO LIBRARY 
